\title{
LITERATUUROVERZICHT BETREFFENDE
}

\section{DE VOEDING EN DE VOEDINGSGEWOONTEN}

\section{VAN DE BOSLANDCREOOL IN SURINAME}

De Boslandcreolen, Bosnegers, Boslandnegers, Marroons of Djoeka's van wie hier sprake is, zijn de naar het Surinaamse binnenland gevluchte Afrikaanse Slaven en hun nakomelingen. Zij zijn voor het merendeel gevestigd in dorpen aan de bovenloop van de rivieren, en wel boven de stroomversnellingen (vallen). Uitzonderingen hierop zijn echter Santigron en Totikamp aan de Saramacca, en de dorpen aan de Cottica. In het westelijk deel van het land zijn geen Boslandcreolen-dorpen gelegen. Omdat het Surinaamse binnenland veel overeenkomst vertoont met het Afrikaanse oerwoud, kon de Boslandcreool zich zeer goed aan het nieuwe milieu aanpassen.

Door de slavenhandel zijn in de loop der tijden ongeveer 300.000 Afrikanen, voornamelijk afkomstig van de Goudkust, Dahomey en Nigerië, naar Suriname getransporteerd.

Volgens een officiële schatting moeten zich thans 22.000 Boslandcreolen in Suriname bevinden. De tellingen van de Antimalaria-campagnedienst leverden echter een aantal van ongeveer 40.000 op.

De Boslandcreool heeft, wat voedings- en levensgewoonten betreft, het Afrikaanse karakter van zijn voorouders voor een groot deel behouden, maar toch ook elementen overgenomen van de:

I. Indianen: cassavebrood, wilde vruchten, barbakotten, casripo.

2. Europeanen: alcohol, keukengerei, keukentechniek, geweer.

3. Israëlieten: zindelijkheid, verboden spijs (varken, ongeschubde vis), onthouding van het gebruik van warmbloedig wild en jacht hierop op zaterdag. 
De volgende factoren zijn echter eveneens van grote invloed geweest:

I. De slavernij: onvolwaardige kost, alcoholisme (blote calorieën om hard te kunnen werken), afkeer van de landbouw.

2. Het plantageleven: eenzijdige voeding, bedelen, inkopen.

3. De achtervolging: wilde vruchten, verscholen kostgronden, geen veeteelt.

4. Het binnenland-milieu: roofbouw, visvangst, bosproducten (palmwijn, wilde honing).

De levenswijze van de Boslandcreool berust hoofdzakelijk op traditie en religie, terwijl bijgeloof een grote rol speelt in de voedingsgewoonten.

De sociale eenheid is een oso of gezin. De leden van deze oso's behoren tot een uitgebreide familie, béré of buik. Hierbij geldt evenwel alleen de verwantschap in de lijn van de moeder (matrilineaal). Een aantal béré's vormt tezamen een clan of lo (onderstam). Een stam bestaat uit een aantal lo's.

De Boslandcreolen hebben zich tot de volgende stammen gegroepeerd:

I. Aloekoe's: Boven-Lawa

2. Boni's: Lawa

3. Aucaners of Djoeka's: Tapanahoni, Cottica, Boven-Commewijne, Sarakreek

4. Paramaccaners: Midden-Marowijne

5. Saramaccaners: Boven-Suriname

6. Matuari's of Bekoe's: Boven-Saramacca

7. Coeroentiërs: Boven-Saramacca, Boven-Coppename

In het volgende relaas wordt in chronologische volgorde een samenvatting gegeven van de in de aan de schrijver bekende publicaties vermelde gegevens aangaande de voeding. Deze gegevens worden aangevuld met eigen bevindingen. Hierbij is getracht een zekere uniformiteit in terminologie en rangschikking aan te houden. Behalve de eigenlijke voeding en voedingsgewoonten worden ook de levenswijze, voor zover deze hiermede te maken heeft, en de wijze waarop de voedingsmiddelen worden verkregen en bereid, behandeld. De gegevens zijn verspreid over een groot aantal publicaties, die ten dele moeilijk verkrijgbaar zijn. Reeds Staal (I928, p. I84) merkte op: "Er is over de ... Bosnegers in Suriname al vrij veel in het licht gegeven, maar het is over vele geschriften verspreid en wacht nog deskundige ver- 
VOEDINGSGEWOONTEN VAN DE BOSLANDCREOOL 207

werking tot één geheel". Op het ogenblik is dit probleem bovendien bijzonder actueel geworden in verband met het Brokopondoproject.

VERKLARING VAN ENKELE IN DE TEKST VOORKOMENDE TERMEN

Abongra $=$ abonjera $=$ bongila $=$ sesam $=$ Sesamum indicum (zaad) .

Afoefoe $=$ fijngestampte banaan.

Afrikaanse obé = Elaeis guineensis (oliepalm).

Afringi $=$ domiballetjes $=$ balletjes cassavemeel.

Amana $=$ een soort awarra-palm in de Boven-Suriname $=$ Guilielma speciosa?

Asogri $=$ fijngestampte, geroosterde maïskorrels vermengd met suiker

Awarra $=$ eta-appel $=$ Astrocaryum segregatum (palmvrucht).

Bacove $=$ bakoeba $=$ bakba $=$ pisang $=$ ooftbanaan $=$ Musa sapientum (kruisingen: appelbacove Musa acuminata $\times$ balbisiana).

Balata $=$ wilde rubber $=$ gedroogd melksap van de bolletrie $=$ Manilkara bidentata.

Bambamaka $=$ Desmoncus soorten (palmen).

Banaan $=$ bana $=$ bananen $=$ bakbanaan $=$ meelbanaan $=$ plantain $=$ plantaan $=$ Musa paradisiaca .

Barbakotten $=$ barbecue $=$ roosteren $=$ drogen en roken van vlees of vis op houten stellage boven een vuur.

Basterd bolletrie $=$ bakabé $=$ Humiria floribunda .

Bataat $=$ zoete pataten $=$ switi patata $=$ Ipoemoea batatas (aardvrucht)

Binnenland $=$ bosland $=$ het gebied ten zuiden van de savannegordel

Bittere cassave $=$ bitakasaba $=$ cassavewortel $=$ cassavestok $=$ maniok $=$ maniokwortel $=$ broodwortel $=$ Manihot esculenta (aardvrucht).

Boembi $=$ een visvergif $=$ Tephrosia toxicaria .

Boroma $=$ kapoeweriboom $=$ Pourouma mollis en andere soorten.

Boshen $=$ marai $=$ Penelope marail .

Boskalkoen $=$ powisi $=$ wilde kalkoen $=$ Crax nigra of $C$. alector .

Bosmarmeldoos = Duroia eriophila (boompje).

Bosmispel = Mouriria soort (vruchtboom).

Broodvrucht $=$ broodboomvrucht $=$ bredebong $=$ Artocarpus communis.

Brulaap $=$ baboen $=$ Alouatta senicula .

Capasi $=$ kapasi $=$ bongo $=$ gordeldier $=$ Dasypus novemcinctus, $D$. kappleri en Priodentes giganteus.

Cassave $=$ kasaba $=$ bitakasaba $=$ bittere cassave $=$ Manihot esculenta (aardvrucht).

Cassavebrood $=$ cassavekoek $=$ maniokbrood $=$ maniokkoek $=$ brood $=$ koek $=$ tot grote, ronde, platte broden gebakken cassavemeel.

Dasjien $=$ dasini $=$ Chinese tayer $=$ Colocasia esculenta (aardvrucht). 
Djoekapinda $=$ agobo $=$ gobogobo $=$ bosnegerpinda $=$ Voandzeia $s u b$ terranea (aardnoot).

Doeka $=$ Tapirira guianensis (boom).

Domi $=$ meel van bittere cassave $=$ cassavemeel $=$ tokoe $=$ met water gekookt, gezeefd cassavemeel.

Dram $=$ djojo $=$ inheemse rum uit gegist suikerrietsap.

Fleskalebas = Lagenaria leucantha.

Gobogobo $=$ bosnegerpinda $=$ Voandzeia subterranea (aardnoot).

Godo $=$ fleskalebas $=$ Lagenaria leucantha.

Gogomango $=$ Phytolacca rivinoides (groentesoort).

Granjaba = Caperonia palustris (kruid).

Groot-Opperhoofd = Granman = Gouverneur $=$ Opperhoofd van een Boslandcreolenstam.

Jaguar $=$ tigri $=$ pakiratigri $=$ Felis onca .

Jan Snijder = Pouteria guianensis (boom).

Kalebas $=$ krabasi $=$ Crescentia cujete.

Kamina $=$ Heteropsis jenmani (struik).

Kaumaka $=$ Acrocomia aculeata? (palm).

Keskes'maka $=$ Bactris soort (palm).

Kimboto $=$ kodibiosi $=$ Pouteria surinamensis en andere boomsoorten .

Klaroen $=$ kraroen $=$ Amaranthus caudatus, A. lividus of A.dubius (groentesoorten).

Koekoe = gestampte, rauwe, rijpe banaan en cassavemeel, tezamen gebakken.

Koemboe $=$ koemoe $=$ Oenocarpus bacaba (palmvrucht).

Koenami $=$ bogo $=$ een visvergif $=$ Clibadium surinamense of $C$. sylvestre .

Kostgrond $=$ akker $=$ tuin $=$ kostakker $=$ kosttuin $=$ cassavegrond $=$ wisselgrond $=$ veld $=$ grondje $=$ plantage $=$ pranasie $=$ grong $=$ boiti = opengekapt en gebrand stuk oerwoud, waarop gewassen worden geteeld.

Kouseband = Vigna unguiculata (peulvrucht, groente).

Kwak = geroosterd cassavemeel bestaande uit droge, gele korrels.

Kwatta $=$ kwata $=$ een grote, zwarte aap $=$ Ateles ater .

Kwattabobi $=$ kwatabobi $=$ Chrysophyllum cuneifolium (boom, laurierkers?).

Lagosofoeta $=$ kodibiosiballi $=$ Pouteria soort (boom).

Lemmetje $=$ een klein soort citroen $=$ Citrus aurantifolia.

Locus = Hymenaea courbaril (boom).

Maïs $=$ koren $=$ karoe $=$ Guinee koren $=$ Indisch koren $=$ Indiaanse tarwe $=$ Turkse tarwe $=$ Zea mais.

Malobi $=$ bataballi $=$ batambali $=$ Ecclinusa guianensis (boom).

Mapa $=$ amapa $=$ pera $=$ Couma guianensis (vrucht).

Maripa $=$ Maximiliana maripa (palmvrucht). 
Matapi $=$ cassavepers $=$ een uit warimbo gevlochten, cylindervormige, 5 voet lange, elastische buis, waarin de geraspte bittere cassave wordt uitgeperst en aldus ontdaan van het blauwzuur bevattende sap.

Mauriti $=$ Mauritius-palm $=$ mauricie $=$ morisi $=$ Mauritia flexuosa .

Miereneter $=$ mierenbeer $=$ mirafroiti $=$ mangohosoe $=$ tamanoea $=$ Myrmecophaga tridactyla of Tamandua tetradactyla.

Mispel = Bellucia grossularioides (vruchtboom).

Mokomoko $=$ een rivieroeverplant $=$ Montrichardia arborescens.

Monki-monki $=$ kleine grijsgroene aap $=$ Saimiri sciureus .

Nappie $=$ napi $=$ Dioscorea sativa of D. trifida (aardvrucht).

Nekoe $=$ een visvergif $=$ Lonchocarpus chrysophyllus .

Obia $=$ amulet $=$ talisman $=$ bezweringsmiddel $=$ de magische $k r a c h t$ en wijsheid die alleen ten goede kunnen worden aangewend.

Pakira $=$ bosvarken $=$ Tagassu tajacu .

Palmboomwijn $=$ het gegiste sap uit een palmboomstam.

Palmboomworm $=$ zwarte korenworm $=$ groegroe $=$ de larve van de palmsnuittor $=$ Rhynchophorus palmarum .

Parasolmier $=$ bladsnijdende mier $=$ loopmier $=$ bladsnijdster; laaglandparasolmier = Atta cephalotes; hooglandparasolmier $=\mathrm{Atta}$ sexdens.

Pera $=$ amapa $=$ Couma guianensis (boom).

Pimbadotie $=$ heilige witte klei.

Pina $=$ prasara $=$ Euterpe oleracea $($ palm).

Pinda $=$ pistaches $=$ aardpistaches $=$ pienda $=$ Arachis hypogaea (aardnoot).

Pingo $=$ bosvarken $=$ Dicotyles pecari .

Pireng $=$ piren $=$ piranha $=$ zoetwaterhaai $=$ Pygocentrus piraya , Serrasalmus rhombeus of S. gymnogenys.

Plokoni $=$ prokoni $=$ Inga alba en soms andere boomsoorten.

Ponsen $=$ het beurs slaan van gifplanten om daarmede een kreek te vergiftigen.

Ponsoe $=$ grote visvangst met visvergif.

Riemhout $=$ Micropholis guyanensis.

Rijst $=$ alesi $=$ bergrijst $=$ bosnegerrijst $=$ droge rijst $=$ drooglandrijst = Oryza sativa.

Sali $=$ Tetragastris soorten (bomen).

Savanna kwarie = Byrsonima soort (boom).

Singrassi $=$ singrasi $=$ vezelsoort $=$ Bromelia karatas .

Sokosoko = Macoubea guianensis (boom).

Sterappel $=$ Chrysophyllum cainito.

Switibontji $=$ swit'bonki $=$ Inga soorten (vruchtbomen).

Tabak $=$ tabaka $=$ Nicotiana tabacum.

Tabbetje $=$ riviereilandje.

Tapioca $=$ zetmeel dat bezinkt uit het perssap van de bittere cassave. 
2IO VOEDINGSGEWOONTEN VAN DE BOSLANDCREOOL

Tapir $=$ wilde koe $=$ buffel $=$ bofroe $=$ Tapirus terrestris.

Tayer $=$ tajer $=$ taja $=$ Xanthosoma sagittifolium (aardvrucht).

Tayerblad $=$ tajawiri $=$ taja-wiwiri $=$ Xanthosoma soorten en Caladium bicolor.

Tingimoni $=$ hajawa $=$ Protium soorten (bomen).

Toekoemau $=$ toekoemauw $=$ Astrocaryum tucuma (palmsoort).

Tomtom $=$ afoefoe $=$ gestampte, gaargekookte groene banaan .

Tonkaboon $=$ Dipteryx odorata en $D$. punctata (palmsoorten).

Treef $=$ trefoe $=$ taboe $=$ onthouding $=$ spijsverbod $=$ verboden spijs of handeling $=$ een voedingsmiddel dat $\mathrm{bij}$ voortgezet gebruik aanleiding zou geven tot het ontstaan van lepra.

Vijzel $=$ mata $=$ houten vijzel $=$ vijzelblok.

Walaba $=$ Eperua falcata (boom).

Warimbo $=$ Ischnosiphon gracilis en I. obliquus (kruidachtige planten voor vlechtwerk).

Yams $=$ jams $=$ njamsie $=$ yamesi $=$ ignames $=$ Dioscorea alata (aardvrucht).

Zeephout $=$ sopohoedoe $=$ Caryocar microcarpum (palm).

Zoete cassave $=$ switie kasaba $=$ Manihot esculenta (aardvrucht). 


\section{CHRONOLOGISCH LITERATUUROVERZICHT}

HARTSINCK (1770) bespreekt de achtervolging van de weggelopen Slaven of Marrons. Zij zijn 5000-600o man sterk, wonen in de bossen en roven en moorden op de plantages.

Tijdens de tegen hen ondernomen veldtochten worden hun dorpen en kostgronden verbrand. Aangetroffen worden: banaan, hoenders, potten, pannen en zilveren eetgerei (van de plantages). Wild wordt verkregen door schieten met pijl en boog alsook door zetten van vallen en strikken.

$\mathrm{Bij}$ de onderhandelingen betreffende het vredesverdrag op Auca, in I760, worden de Europese gecommitteerden goed onthaald op wildbraad, vis, cassave, banaan, peper en een uit suikerriet bereide dram, die naar cider smaakt. Omgekeerd krijgen de Boslandcreolen van het Gouvernement voortaan jaarlijks: geweren, kruit, lood, bijlen, kapmessen, vuurstenen enz.

STEdman (1799, I800) vertelt in de beschrijving van zijn expedities tegen de weggelopen Slaven - van 1772 tot 1777 - het een en ander over hun voeding.

De vernuftigheid van de Neger wanneer hij zich in de bossen bevindt, is ongemeen groot. De bosbewoners beroemen er zich op dat het hun aan niets ontbreekt. $Z_{i j}$ zijn dik en vet. Door middel van strikken vangen zij in de moerassen wild en vis in overvloed, welke in rook worden gedroogd.

De uit Afrika aangevoerde Slaven waren deels rijst-, deels maïs- of gersteters. - De velden der Marrons zijn beplant met rijst, maniok (cassave), ignames (yams), plantain (banaan) en Indisch koren (maïs). Ook duivenof angolabonen worden gaarne gegeten.

Zout wordt uit de as van palmbomen gemaakt. Heel dikwijls wordt in de plaats van zout rode peper gebruikt. - Boter wordt bereid uit palmboomwormen. Boter uit pistaches (pinda) wordt in soep gebruikt. - De in het bos aanwezige wilde bijen leveren een uitmuntende honing.-Palmboomwijn wordt verkregen door het sap uit een insnijding van een vierkante voet uit de neergehouwen stam in een pot op te vangen en dit te doen gisten. De wijn is sterk genoeg om dronkenschap te veroorzaken.

Vee, pluimvee en honden worden er niet op na gehouden. Het geluid van deze dieren zou het verblijf van de 'muitelingen' kunnen verraden.

De kalebas wordt verwerkt tot flessen, schalen, schotels en drinkschalen, die worden versierd door 'misselijke' insnijdingen. Soms worden de groeven met krijt opgevuld hetgeen een fraaie indruk maakt. - Vuur wordt ontstoken door twee stukken hout tegen elkander te wrijven. - In warimbo's of manden worden tijdens de vlucht de gewassen vervoerd. Soms worden de plantages geplunderd, waarbij ook zilveren borden, messen en porselein worden meegenomen.

LAmmens (1805) vermeldt, dat het voedsel van de Aucaanse Boslandcreool bestaat uit: banaan, tayer, rijst, maïs, alsook verse aard- en peulvruchten; voorts uit hetgeen de jacht en de visserij opleveren. Zij zijn grote liefhebbers van sterke drank (dram of gegist suikerrietsap) en kweken wat rijst en pinda om te verkopen. 
VAN DEN Bosch (1818) beweert dat de weggelopen Slaaf aan de Coppename en Saramacca in overvloed leeft. - Uit een palmiet wordt boter, uit 'aard-pistaches' (pinda) olie, en uit de as van een palmboom zout bereid. - Door middel van vallen worden vis en wild in overvloed gevangen. Dit voedsel wordt geconserveerd door het te roken en te drogen. - De velden zijn overdekt met rijst, cassave en banaan. Ook wordt rode peper gebruikt. Er is een overvloed van palmboomwijn, terwijl de wilde bijen honing leveren.

VAN Eyck (1830) stelt vast dat de dorpen van de Saramaccaners I5-85 huizen tellen. Deze zijn gemaakt van hout met een dak van Mauritiuspalmbladeren. Ze worden naar verkiezing, zonder enige orde of regelmaat gebouwd. De woning bestaat meestal uit één vertrek, dat dienst doet als keuken, eetzaal, slaap- en rookkamer. Hierin wordt ook wild gebarbakot. De rook dient tevens om ongedierte te verdrijven.

De Boslandcreool bekommert zich niet over de toekomst. Bejaarden en gebrekkigen worden gevoed en onderhouden.

Veelwijverij is geoorloofd. Op huwbare leeftijd wordt de bruid door haar moeder zonder enige plechtigheid aan de man afgestaan. Heeft hij reeds één of meer vrouwen, dan bouwt hij voor haar een afzonderlijke woning. Bij zijn afwezigheid leven zijn echtgenoten in voortdurende twist. Buit wordt onder de vrouwen verdeeld. Overspel vindt meermalen plaats, wordt echter de vrouw hierop betrapt, dan mag de man haar kastijden. Bij menstruatie zondert de vrouw zich af in een hut buiten het dorp; zij mag dan geen huiswerk voor de man verrichten. De zich in deze hut bevindende vrouwen voorzien in haar behoeften door de hierbij aangelegde kostgronden.

Bij de geboorte van een kind wordt de moeder door verwanten geholpen. $\mathrm{Na}$ verloop van $5^{-6}$ dagen verricht $z$ ij weer huiswerk. Het kind wordt gedurende 2 jaar of langer gezoogd.

De dagelijkse werkzaamheden van de man bestaan onder meer uit; jagen, vissen, bearbeiden van de kostgrond, bewerken van hout, bouwen van de hut, ruilhandel drijven en opleiden van de zoon. De vrouw doet het huiswerk, bewerkt de kostgrond en bedient de man. Zodra het kind kan lopen, wordt het naar de kostgrond meegenomen. Het meisje helpt de moeder. Op de leeftijd van 7-8 jaar vergezelt de jongen de vader op de jacht en bij diens andere bezigheden.

Hoewel de Saramaccaner op zijn woning, kleding en spijs erg onzindelijk is, draagt hij goede zorg voor de reiniging van zijn lichaam.

De Boslandcreool verkoopt hout op de plantages of te Paramaribo. Dit geschiedt contant of tegen gedeeltelijke ruil met dranken. Ook worden verkocht: tonkaboon, rijst, pinda, vis, gevogelte en gebarbakot vlees. Ingeslagen worden: geweer, kruit, zout, dram, houwer en bijl. Van het Gouvernement krijgt men om de twee jaren geweer, kruit, sabel, bijl, zaag, ijzeren pot, dram enz. Met de indianen wordt geen handel gedreven. - De hulpmiddelen bij de jacht zijn: geweer, kruit en zelfvervaardigde pijl en boog. Bij de visvangst wordt gebruik gemaakt van: hoek, korf, pijl en boog alsmede stinkhout.

De rivieren en kreken verschaffen de beste vis. De bossen leveren veel wild, zoals: hert, haas, konijn, schildvarken, schildpad, miereneter, buffel, pingo, pakira, bosrat en stekelvarken. Ook bezit hij tam gevogelte 
waaraan echter veel schade wordt toegebracht door slangen, tijgers en trekmieren. Een teveel aan wild en overblijvende vis worden gebarbakot.

De kostgrond wordt boswaarts of langs de boorden van de rivier aangelegd en wel op een afstand van 2-3 uren van het dorp. De grond is zeer vruchtbaar. Geplant worden : rijst, banaan, pinda, cassave, tayer, koffie, suikerriet en tabak. - De waarzegger of loekoeman wordt geraadpleegd om te zeggen of er een goede of slechte oogst te verwachten is.

De Saramaccaner is over het algemeen goed gebouwd en zwaargespierd.

TeEnstra (1835) verhaalt dat de Boslandcreool geheel naakt gaat en armoedig leeft. Hij is zeer morsig met zijn spijzen en dranken, maar ongemeen zindelijk op het lichaam. - De veel twist veroorzakende veelwijverij is geoorloofd. De moeder zoogt het kind gelijk een Eva in het Paradijs. Het oudste knaapje gaat met de vader op jacht.

Maïs, rijst, banaan, pinda, cassave, tayer, nappie, koffie, tabak en suikerriet worden in de vruchtbare grond langs de bovenrivieren en kreken of op tabbetjes verbouwd. - Voor het overige leeft de Boslandcreool bijna uitsluitend van de jacht, waartoe de bossen veel wild opleveren.

Hij verruilt hout, vogels, schildpadden enz. tegen jenever, dram, wapens, kruit, lood, zout, messen, 'tondeldozen', bijlen, enz.

Bosch (1843) gelooft dat de zucht naar geld bij de Aucaanse Boslandcreool zeer groot is. Hij doet geen moeite goede kostgronden aan te leggen, maar verruilt liever houtwaren tegen levensmiddelen zonder te beseffen dat hij twintig bossen banaan bekomt voor hout dat hem veertig gulden zou opbrengen. - Hierbij moge worden aangetekend dat honderd bossen banaan in die tijd minder dan veertig gulden kostten.

Hostmann (1850) schat het aantal Boslandcreolen op 80oo. Hun verblijfplaatsen zijn op riviereilanden gelegen. $\mathrm{Zij}$ leiden een zwervend bestaan. In het algemeen zijn zij sterk van gestel. Mismaakten worden zeer zelden aangetroffen.

De hutten zijn wanordelijk geplaatst; nu eens zeer dicht op elkaar, dan weer door bospaadjes gescheiden. - Het geraamte van het gebouw bestaat uit rondhout, het dak uit het loof van verscheidene palmen. De woning telt twee vertrekken, heeft geen vloer, en is van binnen alleronzindelijkst. De grond om het huis wordt echter altijd schoongehouden.

De huiselijke omstandigheden zijn de armoedigste en ellendigste die men zich kan indenken. Het bestaan is wisselvallig. De Boslandcreool leeft nu eens in overvloed, dan weer sober; soms lijdt hij honger. Onder gewone omstandigheden is men echter rijkelijk van voedsel voorzien. In tijden van gebrek leeft de Boslandcreool ten koste van zijn buren, dat wil zeggen vooral van het geciviliseerde gedeelte van het land. Hij bedelt om levensbehoeften.

De arbeid bestaat uit het vangen van vis, jagen en aanleggen van kostgronden. Reeds vroeg vergezellen de kinderen hun ouders op de visvangst en de jacht. - Voor hout, schildpad en vis, op de plantages geleverd, ontvangt de Boslandcreool dram en hierdoor weet hij bij de Plantageneger en Indiaan aan de kost te komen. 
Op de jacht gebruikt hij: geweer (meestal defect), kruit, houwer, mes, val, jachthond (verkregen door ruil tegen ijzerwaren met de Bovenlandse Indiaan), pijl en boog, en houten lans. Met pijl en boog weet hij minder goed om te gaan dan de Indiaan. - Voor de visvangst zijn in gebruik: hoek, vruchten- en dierenaas, korf, nekoe en andere bedwelmende plantaardige vergiften. Door het visvergif worden soms meer vissen ineens gedood dan gebruikt kunnen worden.

De Boslandcreool geeft aan gezouten dierlijk voedsel de voorkeur, maar moet zich noodgedwongen wel eens met vers wild en verse vis voeden. De bossen leveren hem: buffel, hert, pakira en pingo (deze beide in kudden van 500-600), kwatta- en brulaap. Soms worden ook gegeten: marmot, luiaard, gordeldier, rat, hagedis en schildpad. Er worden ook nog hoenders gefokt. De bovenrivieren zijn ongemeen rijk aan smakelijke, deels zeer grote vissen. - Indien de jacht en visvangst met het nodige beleid zouden worden uitgeoefend, zou het gebrek aan dierlijk voedsel, dat dikwijls heerst, niet bestaan.

Aangezien het gebruikelijk is bij strafexpedities de kostgronden en levensvoorraad van de weglopers te vernietigen, is de Boslandcreool verplicht meer kostgronden op verschillende plaatsen aan te leggen. $\mathrm{Hij}$ is echter erg lui: hij legt of in het geheel geen kostgronden aan of onderhoudt deze slecht. De kostgrond is op het oeverland gelegen. De boorden van de Marowijne zijn zeer vruchtbaar. Het bos wordt met bijl en houwer geveld en dan verbrand, waardoor vele bestanddelen van de grond vernietigd worden. Het land omspitten is niet gebruikelijk. Geteeld worden: rijst, cassave, maïs, pinda, tabak, suikerriet, banaan en koffie. Ook naast de hut worden koffie en tabak geplant. - Het gewone voedsel uit het plantenrijk is cassave, soms ook rijst. In het wild wordt een rijstsoort met zwarte bolsters aangetroffen, maar de Boslandcreool gebruikt deze niet, omdat ze door boze geesten zou zijn gezaaid (jorka aleisi). - Andere voedingsmiddelen zijn palmpitten, melasse en zout (van de plantages verkregen of uit de pallisadenpalm bereid). - Er wordt zoet water gebruikt.

Misbruik van geestrijke drank is algemeen. Zonder deze zouden de meeste vermaken niet bestaan. De man is doorgaans een groot liefhebber van dram. Niet zelden deelt ook de vrouw in het genot van deze drank.

De Boni-neger heeft grote kostgronden en drinkt minder dram.

KAPPLER (1854) deelt onder de Boslandcreolen o.m. brandewijn uit en ontvangt in ruil cassavebrood, cassave, eieren, Spaanse peper, sinaasappels en schildpadden. - Op de dorpen ziet hij sinaasappelbomen, cocospalmen en koffieplanten.

Veelwijverij is hier gebruikelijk. De vrouw doet het huishouden, beplant de akker en houdt deze schoon. - In tegenstelling tot de Indiaanse is zij zeer zindelijk in haar huishouden. Na elke maaltijd worden de woning en de grond ervoor geveegd met de bloemtros der pinapalm. Potten en ander keukengereedschap worden met zand gepoetst en gewassen.

De Boslandcreool heeft veel meer behoeften dan de Indiaan. Om hierin te voorzien ruilt hij bij de Blanke allerlei handelsartikelen zoals tonkabonen, rijst, schildpadden, jachthonden en vooral hout in tegen dram, melasse, suiker en banaan. Bij een van de dorpen worden pas uit de stad teruggekomen en met dram beladen korjalen aangetroffen. 
VOEDINGSGEWOONTEN VAN DE BOSLANDCREOOL 215

De ontvluchte Slaaf legt zijn eigen dorp aan, waar hij van de opbrengst van zijn akker, van de jacht en visvangst leeft. Hij gaat ook wel op roof uit op naburige plantages. - De Boslandcreool beschouwt de landbouw als een vernederend bedrijf en oefent die daarom slechts dan uit, wanneer hem geen ander middel van bestaan overblijft. In ruil voor in één dag bewerkt hout kan hij wel voor drie tot vier weken levensmiddelen op de plantages krijgen. - Onder elkaar zijn de Boslandcreolen zeer gastvrij. Gaat er één naar een ander dorp, dan vindt hij overal vrije kost en inwoning. Nochtans bestelen zij elkaar bij elke gelegenheid.

VAN Sypesteyn (1854) zegt alleen maar dat de Aucaanse Boslandcreool hout verwerkt en rijst verbouwt, deze verkoopt en daardoor in staat is in zijn behoeften te voorzien.

VAN HoËVELL (I855) vermeldt de volgende aantallen: Boslandcreolen 8000 : Aucaners 3300, Saramaccaners 4300 en Bekoe's of Moesinga's 400. - In de dichte, bijna ontoegankelijke wildernissen leggen zij dorpen aan en bebouwen de omliggende gronden. De vruchten van deze landbouw, gevoegd bij hetgeen de jacht en visvangst opleveren, maken hun onderhoud uit. - De Minister van Koloniën vermeldt in het 'Verslag van het beheer van Suriname en van de staat, waarin de kolonie zich bevindt over I850, dat de Boslandcreool zich te Paramaribo voorziet van kruit lood, dram, zout, siroop en gereedschappen voor de visvangst. De kostgrond wordt bewerkt door zijn vrouwen, van wie het aantal soms twee, drie, ja vier is, en ook door zijn kinderen.

Cateau van Rosevelt \& van Lansberge, aangehaald door Menkman (I946), verklaren in 1873 het volgende over de Boslandcreool aan de Boven-Suriname (van Koffiekamp tot de samenvloeiing van de Gran en Pikien Rio).

Veelwijverij komt hier vrij algemeen voor. Er zijn mannen die 5 tot 6 vrouwen hebben welke meestal in verschillende dorpen wonen. Bij de gedoopten schijnt dit echter slechts bij uitzondering voor te komen.

Van de landbouwgereedschappen gebruikt hij alleen maar een bijl voor het vellen van bomen en een houwer. Spade en houweel zijn hier niet in zwang. - Indien de Boslandcreool een korjaal, geweer en jachthond bezit, wordt hij als een welgesteld man beschouwd. - Het huisraad bestaat onder andere uit een paar ijzeren potten, die te Paramaribo worden aangeschaft, alsmede schalen, kommen, lepels en schotels van kalebas, voorts een houten blok met stampers voor de rijst en tomtom (van het Afrikaanse toemtoem), en een aarden kruik of pul waarin de vrouw het water uit de rivier op het hoofd naar haar woning draagt.

De kostgronden liggen somtijds twee tot drie dagreizen te water van het dorp. - Cassave is een voornaam voedingsmiddel van de Indiaan van wiens levensgewoonten de Boslandcreool, ondanks alle vijandschap en wederzijdse antipathie, nogal wat heeft overgenomen. - Armoede en gebrek schijnen hier te heersen. Bij gemis aan wild of vis voedt de Boslandcreool zich met rijst en cassave, gedoopt in rivierwater, waarbij een weinig zout wordt gevoegd.

Het wild is door de voortdurende jacht van de meer bewoonde gebieden 
naar het diepe woud verdreven. Vis is door het ponsen of vergiftigen van het water bijna niet te verkrijgen. Aan het kweken van tam gevogelte wordt weinig gedaan. Er heerst dus gebrek aan dierlijk voedsel. - Bedelen doet de Boslandcreool overal op de meest onbeschaamde wijze. Daarentegen weigert hij zelfs de minste dienst te bewijzen zonder vooraf betaling daarvoor te eisen.

Prins Bonaparte (1884) betoogt dat de voeding van de Boslandcreool in hoofdzaak plantaardig is. Hij gaat echter vaak op jacht en uit vissen, om zich kleine hoeveelheden wild en vis te verschaffen die hij toevoegt aan zijn dagelijks menu, dat voornamelijk uit rijst en cassavebrood bestaat. - Het is de vrouw die belast is met het bewerken van de tuinen. Gedurende het gehele jaar cultiveert zij yams, bataat, tayer en cassave. Tijdens de droge tijd produceert de grond nog vanaf september tot november een zeer zetmeelrijke en smakelijke wortel, nappie genaamd. Van tijd tot tijd maakt de Boslandcreool een reis naar de meest nabije plantages om er boomstammen die hij heeft geveld, te ruilen tegen banaan waarop hij dol is.

Door cassave met water te vermengen wordt een brij verkregen die op een ijzeren plaat wordt gebakken. Dit brood heeft een zeer goede smaak en is lang houdbaar. - Bij het voedsel wordt steeds een grote hoeveelheid inheemse peper gevoegd. Zout is een zeer gewild artikel. - Een soort soep bereid uit wilde peulgewassen wordt zeer gewaardeerd. Hierbij wordt nog afoefoe, cassavebrood of rijst gevoegd. - De Boslandcreool is een groot liefhebber van pinda. Hiermede worden tal van lekkernijen bereid. Ook is hij dolgelukkig met spek. Telkens als hij naar de stad gaat, schaft hij zich hiervan vaten vol aan, hetzij gezouten, hetzij gerookt. - Er wordt geen meel gekocht, behalve wanneer de rijstoogst slecht is geweest.

De gewone drank is water uit de rivier of kreek. Heel vaak wordt inheemse rum, genaamd dram, gebruikt, door hemzelf bereid door suikerrietsap te doen gisten. Het suikerriet wordt van de plantages verkregen. Gedurende een feest worden aanmerkelijke hoeveelheden van deze dram geconsumeerd. - Op wijn is de Boslandcreool niet dol. De man geeft de voorkeur aan jenever en bier, terwijl de vrouw verzot is op likeur.

Coster (I886) schrijft dat het dagelijkse voedsel van de Boslandcreool meestal bestaat uit rijst, zoete cassave en uit cassavebrood, een smakelijk, lang houdbaar levensmiddel, dat op een ijzeren plaat wordt gebakken.

In de grote droge tijd levert de grond nappie. Het gehele jaar door worden yams, bataat, tayer en cassave verbouwd. Banaan wordt van tijd tot tijd tegen hout op de plantages ingeruild. Wild en vis weet de Boslandcreool zich door jacht en visvangst te verschaffen. De jongens worden reeds vroeg op de jacht en visserij meegenomen. Zout is een zeer gezocht artikel.

Het voedsel wordt steeds met veel inlandse peper toebereid. In soep of blaf worden bosgroenten (klaroen en tayer) gekookt. De soep wordt met afoefoe genuttigd, of anders wordt cassavebrood of rijst erin gedoopt. - De Boslandcreool is een groot liefhebber van pinda, waarvan verschillende lekkernijen worden gemaakt. - Gezouten en gerookt spek worden in de stad gekocht, dikwijls met vaten vol. - Blom of meel wordt alleen ingeslagen wanneer er een slechte rijstoogst is. 
Als drank gebruikt de Boslandcreool rum of dram. Soms maakt hij van het sap uit suikerriet, dat hij op de plantages verkrijgt, een soort van gegiste drank die hij vooral bij feesten gebruikt. Hij geeft aan jenever en bier de voorkeur boven wijn. De vrouw houdt veel van likeur. - Vele mannen en vrouwen roken Amerikaanse tabak uit korte Goudse pijpen. Het snuiven is bij sommigen een hartstochtelijke gewoonte.

Water, sterke dranken, suikerrietsap, rijst, zout e.d. worden in kalebassen of godo's bewaard. - Lepels worden van de kalebas gemaakt. - De vrouw is voorbeeldig zindelijk. Kommen en pannen worden altijd uitermate goed schoongehouden. Ook bij het koken van het eten wordt de meeste reinheid in acht genomen. De haard of vuurplaats bevindt zich in de hut.

Bij de maaltijd komen dikwijls vele mannen tezamen in één hut. De vrouwen verwijderen zich, na verschillende kalebassen of kommen met eten voor haar mannen in de kring waarin deze gezeten zijn, op zeer lage tafeltjes te hebben geplaatst, waarbij zij nimmer vergeten een grote kalebas met water te voegen om vóór en na het eten de handen te wassen. - De vrouwen komen later in een andere hut bijeen om hetgeen zij vooraf voor zich hebben achtergehouden en wat door de mannen is overgelaten te gebruiken. - Bevindt zich een grijsaard of hooggeplaatste in hun midden dan wordt deze de kalebas of kom met eten het eerst aangeboden opdat hij daaruit kan nemen wat hij verlangt, en dit van een gewoon bord nuttigen, terwijl de anderen uit de grote kom hun maaltijd verorberen. Over het algemeen wordt onder het eten met elkaar gepraat aan welk gesprek dan ook de hooggeplaatste deelneemt.

LICHTVELD \& VOORHOEVE (1958) voeren het een en ander aan uit het 'Boek der dromen' of 'Skrebiboekoe' van JoHANNES KING, geschreven in 1888 .

De naar het bos gevluchte Slaaf (Boslandcreool) nuttigt vele boszaden, wild, gevogelte en vis. Boszout wordt bereid uit de bast van verschillende bosboomsoorten. - De vrouw vervaardigt grote aarden potten en pannen. - Bij het plunderen van de plantages brengt de Boslandcreool zoveel hij dragen kan met zich mede naar het bos.

JoEst (1893) constateert dat de dorpen uit 50 en meer hutten bestaan. - Veelwijverij is toegestaan. Gedurende de zoogperiode mag een vrouw geen geslachtelijke omgang hebben. De zoogperiode zal dus niet al te lang duren. - Tot de taak van de vrouw worden gerekend: verzorgen van haar kinderen, zorgen voor de huishouding, bakken van het cassavebrood, zorgen voor de kostgrond en vervaardigen van aardewerk. - Lichaam en dorp worden zindelijk gehouden. Na de maaltijd worden de tanden met vinger en houtstaafje gepoetst en de mond uitgespoeld. Een en ander stamt uit Afrika, al speelt de invloed van de Hernhutters en de slavernij ook een rol.

Voedingsmiddelen worden verkregen door cultivering van voedingsgewassen, verzamelen van bosvruchten, jacht, visvangst, verzamelen van schildpad-eieren en schenkingen van het Gouvernement (bakkeljauw en spek).

Keukengerei en tuingereedschap worden zelf vervaardigd (schaal, 
schotel, waterkruik), verkregen door ruil met de Indiaan tegen brandewijn (aardewerk, schaal, waterkruik, korf, zeef), aangekocht in Paramaribo of Frans Guyana (bijl, bosmes, dure Boheemse glazen, zilveren koffieservies), dan wel door het Gouvernement geschonken (bijl en slijpsteen). Bij het keukengerei behoren ook nog: drinknap en lepel van kalebas die met insnijdingen worden versierd, vijzel en stamper. De Boslandcreool kan vuur maken zonder lucifer, brandglas, staal of vuursteen.

De jachtmiddelen zijn: pijl en boog (vogel, schildpad), geweer en val (grof wild). De Boslandcreool is bekwaam in het jagen, alhoewel hij hierin door de Indiaan wordt overtroffen. Jachthonden zijn niet waargenomen. De visvangst geschiedt met pijl en boog, hetgeen van de Indiaan is overgenomen.

Van de veldproducten moeten worden genoemd: cassave, maïs, yams, banaan, nappie en bataat. - De uitgeperste cassavewortel wordt in een plompe vijzel tot meel gestampt. Alle palmdaken zijn bedekt met witte versgebakken cassavebroden die in de zon drogen. Ze zijn ongeveer viermaal zo groot als pannekoeken. Het cassavebrood van de Boslandcreool is beter dan dat van de Indiaan, aangezien de eerstgenoemde het cassavemeel tweemaal zeeft.

Water wordt uit de handpalm of uit een kalebas gedronken. - De Boslandcreool drinkt heel gaarne een fles porter of bier en ook wel een glas brandewijn, vooral wanneer hij er niet voor hoeft te betalen. Hij mag zich weleens bedrinken, maar een dronkaard is hij niet. Hij bereidt noch koopt bedwelmende dranken.

De Boslandcreool is groot en krachtig gebouwd. Hij heeft een brede borstkas en gespierde armen. Minder ontwikkeld zijn echter de onderste ledematen. De benen zijn vaak dun en krom, kennelijk een gevolg van het steeds hokken in de smalle korjalen. De vrouw en het meisje zijn daarentegen onberispelijk ontwikkeld.

SCHNEIDER (I893) taxeert het aantal Boslandcreolen op 80oo-9ooo. Reeds in 1668 zijn er ontvluchte Slaven die wapens en werktuigen naar het bos meenemen. Geleidelijk breiden zij zich verder uit in de gebieden van de Indiaan. Soms komt het daarbij tot een bloedige oorlog. De wildernis vertoont grote overeenkomst met het Afrikaanse stamland. - De kampen, dorpen of nederzettingen zijn aan een rivier of beek gelegen en wel op een verscholen en moeilijk toegankelijke plaats. Zo'n kamp telt 3-4 of $40-50$ woningen. De hutten liggen niet aan een straat, maar zijn door elkaar gebouwd, op een kleine afstand van elkaar. - In het dorp zijn schaduwboom, palm, sinaasappel, oranje en koffie geplant.

De hut telt twee afdelingen. De ene dienende als keukenruimte, zwart door rook, is aan twee of drie zijden open. De andere is de slaapkamer die geheel of aan twee kanten door een vlechtwerk van palmbladeren is afgesloten. Het dak bestaat eveneens uit palmbladeren. Vaak zijn er twee hutten: keuken en woonruimte afzonderlijk. Soms rust de hut op 2-3 voet hoge palen. Overigens leeft en werkt de Boslandcreool onder de blote hemel. Soms is hij maandenlang van huis. Bij vele hutten behoort een voorraadschuur die aan alle kanten is afgesloten.

De Boslancreool huldigt het matrilineale stelsel. - Veelwijverij is meer uitzondering dan regel. Het zijn hoofdzakelijk gegoede en invloedrijke 
VOEDINGSGEWOONTEN VAN DE BOSLANDCREOOL 2 I9.

personen die twee tot drie vrouwen hebben. De broer, oom, tante of grootmoeder bezit de bevoegdheid het huwelijk te ontbinden, zelfs tegen de wil in van het echtpaar. Ook door weglopen van de vrouw vindt echtscheiding plaats. - 's Morgens en na terugkomst van de jacht of van de kostgrond wordt een bad genomen. Gewoonlijk wordt na elke maaltijd de mond uitgespoeld en het benijdenswaardig wit gebit goed onderhouden. Het keukengerei wordt na gebruik in de rivier met zand blankgepoetst. Het terrein wordt geregeld geveegd. Alleen de last die zij ondervinden van luizen, is in tegenspraak met deze reinheid.

Er wordt met een lepel gegeten. Keukengerei en dienblad worden in de keuken bewaard. - Het voedsel wordt bereid door koken, braden, bakken, en roosteren. - De voedingsmiddelen worden verkregen door het kweken van gewassen op de kostgronden en in de dorpen, door jacht, visvangst, kippenteelt, aankoop, ruilhandel en bedelarij. - Hout wordt in Paramaribo verkocht. Ingeslagen worden: werktuigen, jachtattributen en levensmiddelen zoals banaan, zout, rum, dram en melasse. Van het Gouvernement worden nog ontvangen: ijzerwaren, werktuigen, geweer, kruit en lood.

Vleeskost verschaft de Boslandcreool zich door jacht op leguaan, tapir, hert, haas, aap, watervarken en vogel. De enige huisdieren zijn jachthonden (die hij van de Indiaan koopt) en hoenders. Gevist wordt met pijl, haak en nekoe. Door dit visvergif worden ook de jonge vissen gedood. Er is een overvloed aan wild en vis in de wildernis.

Dezelfde kostgrond wordt zelden meer dan eens beplant en levert slechts één of twee oogsten op, omdat de bodem niet wordt bemest. - De man velt de woudreuzen en kapt er de hoofdtakken af. De vrouw verwijdert de kleinere twijgen, hoopt ze op en verbrandt ze. Hij nivelleert de grond en maakt de aarde los. $\mathrm{Zij}$ plant het zaad, wiedt, oogst en vervoert de producten naar huis. - Bij misoogst ontstaat hongersnood. Dan wordt aan de kust en bij het Gouvernement gebedeld.

Rijst en cassavewortel vormen het hoofdvoedsel. Daarnaast worden maïs en geroosterde pinda gebruikt. Yams en banaan worden zelden gegeten. Koffie wordt wel geplant, maar de bonen worden verkocht en niet verwerkt tot drank. - De Boslandcreool gebruikt weleens rum of dram, doch hij is een nuchter mens en verafschuwt dronkenschap.

Een obia zou onder meer geluk aanbrengen op de jacht. Zelfs de hond krijgt zo'n voorwerp om de hals opdat hij het wild goed kan opsporen. Vruchtbomen worden ermede behangen ten einde veel te dragen. De amuletten worden door de toverdokter en niet zelden door Joodse zakenlieden in Paramaribo te koop aangeboden. Een kandoe of beschermingsmiddel vóór de kostgrond geplaatst, zou onbevoegden weren.

Het bovenlichaam van de Boslandcreool is krachtig, met sterke nek, brede borst en gespierde armen. Het onderlichaam daarentegen laat te wensen over door zijn diepingebogen kruis, te sterk ontwikkeld zitvlak en onderlijf, en de te dunne, bijna kuitloze benen.

HERING (I9OI) toont aan dat cassavebrood het hoofdvoedsel is van de Boslandcreool. De cassaveteelt eist niet veel arbeid. Nadat de cassavewortel van alle aankleefsels van aarde of zand is afgewassen, wordt hij enige uren in zoet water gelaten, daarna van de rode schil ontdaan, vervolgens fijn geraspt, van het giftige sap bevrijd door uitpersen, 
in de zon gedroogd en tenslotte in ronde vormen op een ijzeren plaat boven een matig vuur gebakken en daarna wederom in de zon gedroogd. - Een tweede cassaveproduct is kwak, die de volksspijs is van de Boslandcreool aan de Marowijne. Na de voorbereiding als bij cassavebrood, wordt het meel met een stok op een hete ijzeren plaat omgeroerd totdat het korrelig en bruinrood wordt. Hierna wordt het in de zon gedroogd en tenslotte in zakken of kisten verpakt. Kwak kan worden gekookt en met suiker of vlees worden gebruikt. Op reis wordt de ruwe kwak in een kalebas gedaan met water vermengd, omgeroerd en genuttigd. - Ook worden nog rijst en pinda door de Boslandcreool geteeld.

VAN ColL (1903) geeft de volgende definitie voor het begrip Marrons: Afrikanen die al aanstonds of kort na hun overvaart naar West-Indië van de slavenschepen of van de plantages ontvluchtten en nu de Afrikaanse levenswijze in de bossen voortzetten.

De ontvluchte Slaven nemen zaairijst, suikerriet-, banaan-, bacove-, nappie- en tabaksplanten, alsmede huisraad, keukengerei, houwer, bijl en ander gereedschap van de plantages mee. In het holst van de nacht dringen zij tot de plantages door, plunderen, moorden en voeren Slaven met zich naar het bos. De patrouilles die hen achtervolgen, mogen woningen en kostgronden vernielen, potten en pannen verbrijzelen; het kan hen tijdelijk in verlegenheid brengen, maar niet vastzetten. $Z_{i j}$ weten zichzelf te behelpen met bosvruchten en zaden. Aan kennis om partij te trekken van de voortbrengselen van het bos ontbreekt het hen niet; kennis die zij ook reeds op de plantages hebben opgedaan.

Het aantal Boslandcreolen wordt op het einde der 18e eeuw op 26.000 geschat. - Meestal zijn de dorpen gelegen in de nabijheid van een rivier of beek op leem- of kleigrond.

De huizen staan niet op een rij, doch het ene is twee tot drie minuten, of althans ettelijke schreden van het andere verwijderd. De paden zijn in de regel hard. - De huizen zijn vierkant. Het dak bestaat uit het loof van de pinapalm. De ovaalvormige woningen aan de Surnaukreek hebben vier uitgangen, ten einde bij achtervolging het ontsnappen gemakkelijk te maken. - De paden, de lemen vloer van de woning, het meubilair, het keukengerei alsook het lichaam en de kleren worden onberispelijk zindelijk gehouden. Zo nodig wordt met zuur en zand geschuurd. De kommen worden steeds bedekt met een bord. Als zeepsurrogaat dienen: indjisopoblad, zeepboomvrucht en loog uit de as van de rijststengels.

De verloving geschiedt met een feestmaaltijd en eist de goedkeuring van het Opperhoofd. Bij het sluiten van hetgeen als echtelijke verhouding geldt, wordt enige eerbied in acht genomen jegens bloedverwanten, vooral wat betreft die van moederszijde. De eerste vrouw mag nooit worden verlaten. Wordt de echtgenote op overspel betrapt, dan wordt zij gekastijd.

Op de plantages worden de koks uit de slaven gekozen. Er zijn er die de kookkunst goed verstaan. In noodgeval kunnen zij alles, tot hun soep toe, doodeenvoudig in een gat in de grond koken. De brede bladeren van de paloeloe worden daartoe kruiselings over het gat uitgespreid en met de hand zo glad mogelijk ingedrukt. Daarop wordt water gegoten waardoor de bladeren beter sluiten. Vlees, zout enz. gaan er nu in. Dan worden . de bladeren van boven omgehaald en over elkaar gelegd zoals van onderen. 
Heel voorzichtig wordt vervolgens het gat in de grond met aarde of klei aangevuld waarna een vuur erboven wordt gestookt. - Bij het nuttigen van de maaltijden wordt geen gebruik gemaakt van de hiertoe te kleine tafels. Er wordt niet op vaste uren gegeten: de maag is de klok. Men eet niet gezamenlijk; ieder kiest een plaats voor zich afzonderlijk: binnensof buitenshuis, aan de deur, dan wel in een hoek. - Van het keukengerei moeten worden genoemd: vijzel, suikerrietpers, houten suikermolen, schuimvat om alcoholische drank te bereiden, kalebaskom, aarden pot, gevlochten koemboe-pers en mand, ketel, pan, mes, glas, porseleinen bord, fles en tondeldoos.

Onder de ontvluchte Slaven bevinden zich ook smeden, die uit oudijzer allerlei nuttige voorwerpen zoals messen vervaardigen. - Tondel groeit wel niet aan de bomen, maar toch wordt een surrogaat-tondel aan sommige planten gevonden. Ook obé levert aan de uitwassen een surrogaattondel. Vuursteen komt ook in overvloed voor, en waar die ontbreekt worden harde potscherven gebezigd. Een stuk ijzer, met wit slijm van het excrement van een hagedis bestreken, in een bepaald bad gestopt en daarna gegloeid, dient als vuurslag. - Kisten en alle verder gerief worden uit de opbrengst van hout te Paramaribo gekocht. Tafel, bankje, aarden pot, mand, korf, zak, bezem, schuimvat, mes, suikerpers, suikermolen en lans worden zelf vervaardigd.

Voor de jacht worden gebruikt geweer, ammunitie en opgesteld geweer. Op de buffeljacht wordt een lans gebruikt: een aan drie zijden snijdend plat stuk ijzer aan een steel die in een geweerloop past. - Gevist wordt met behulp van een houwer of mes in de avond bij fakkellicht, een korf, een schepnet aan een beugel en visvergif. Sommigen zijn behendig genoeg de vis met de hand te grijpen. Als visvergiften zijn bekend: koenami, koenapaloe, jawrokoenan, nekoe, ahobo of ruggegraatsliaan, oriri of jarithe voor kleine vis, en teteroeman karombanikoro of wane uit de savanna.

Om palmwormen te verkrijgen worden in de stengel van de gevelde palm, meestal de Mauritie-palm, insnijdingen tot op het merg gemaakt. Zekere insecten komen hierin hun eieren leggen. Zes weken later wordt de palm over zijn lengte gekloofd. In het merg worden dan vette wormvormige larven, zo dik als een vinger en twee duim lang, aangetroffen. $\mathrm{Ze}$ worden gebraden. Ook wordt er een soort boter uit bereid. Hiertoe worden ze gezuiverd, sterk uitgebraden en gezouten. Deze boter, calandra palmarum geheten, wordt in een fles bewaard.

Het plantaardig voedsel bestaat uit rijst, nappie, tayer, banaan, broodvrucht en palmkool of kabbes. - Eetbare paddestoel of kampernoelie, bij voorkeur verzameld aan de voet van de barklak en mierenboom, wordt in water gekookt en met peper en zout genuttigd. - Koemboekaas wordt bereid door de geweekte, olierijke pulp om de koemboepitten door stampen te verwijderen. Met peper en zout wordt dit deeg boven een smeulend vuur gedroogd en als kaas opgediend. - Spijsolie wordt uit maripa en koemboe verkregen. Om olie uit maripanoten te maken, worden deze bij het vuur of in de zon gedroogd, dan wel zo lang gekookt, totdat door schudden de kern loslaat. Vervolgens wordt deze er uitgehaald, opnieuw gedroogd, in de vijzel gestampt en gekookt tot alle olie eruit is. Verdikt lijkt de olie op kaas, maar smaakt naar teer. Koemboe-olie wordt bereid door de pitten zolang te koken tot de vetdelen zich beginnen af te scheiden. 
Het water wordt dan afgegoten. De pulp en kern worden in een grote vijzel gestampt en daarna onder aanhoudend roeren in een droge pot op het vuur verwarmd, waarbij zich de olie afscheidt die vervolgens wordt uitgeperst in een soort matapi. (Dit woord betekent slang in het Indiaans). De olie is lichtbruin en blijft steeds vloeibaar. Deze twee oliën worden als boter bij cassave gebruikt en ook bij het bakken van vis.

De volgende vruchten worden aangetroffen: ananas, bacove, casjoe, koemboe, locus, maripa, papaja, bosvruchten en -zaden. Tussen de woningen wordt wat papaja, casjoe, bacove en peper geplant. Met suiker vermengd, wordt het afgeweekte gelei-achtige vruchtvlees van de koemboe als brij gegeten.

Van het blad van de paloeloe wordt een zak vervaardigd om drinkwater over grote afstand te vervoeren. Water wordt ook verkregen uit de paloeloe en diverse lianen, zoals de kau- of watratetei. - Met warm water verdund, wordt suiken rietsap in plaats van koffie en thee gebruikt. - Uit koemboe wordt een soort chocoladedrank bereid, door de pitten met warm water te weken, dan de pulp er af te stampen en tenslotte met suiker te vermengen. - Een kostelijke drank is honing. Voorts worden ook nog ananassap en vers sap uit de stam van de Mauritiuspalm alsmede stroop daaruit bereid, gedronken. Uit deze palm wordt tot tien liter palmsap verkregen; door gisting wordt hieruit ook een alcoholische drank bereid. - Uit suikerrietsap maakt de Boslandcreool dram. Hij heeft zelfs een geïmproviseerd destilleerapparaat in gebruik, vervaardigd uit oude ketels of potten, holle bospapaja, geweerloop en katoenen breeuwwerk met hars. Door gisting van ananassap en uitgeperst vocht van casjoeperen worden eveneens alcoholische dranken verkregen. Verder is het ondenkbaar dat aan de Boslandcreool de Indiaanse tapana en casiri onbekend zouden zijn. - Het afkrabsel van de kalebasboombast, een tijdlang in de mond gehouden, dient als middel tegen dronkenschap.

Uit de maripapalm wordt door verassing boszout bereid. Na twee dagen te zijn afgekoeld, wordt de as in fijne mandjes opgevangen. Dan moet zuiver water er twee tot driemaal doorsijpelen. Na koken en verdampen van dit water blijft het boszout achter.

De Boslandcreool nuttigt een berg eten. De hoofdschotel is rijst. Nochtans worden tayer, nappie, banaan en vooral cassave niet versmaad. Bij de rijst en de cassave wordt gevoegd hetgeen jacht en visvangst levert. Is deze opbrengst van weinig belang, dan worden vetten en oliën van eigen fabrikaat gebruikt. Honing wordt tweemaal daags aan de kleinen toegediend, en wel des morgens en des avonds tot zij hun bekomst hebben.

VerSTEEG (1905) noemt de Djoeka een aartsbedelaar. Geen voorwerp, geen stuk kleren van de Blanke waar niet ten minste driemaal om gevraagd wordt. Vooral om tabak, sterke drank en medicijn wordt onophoudelijk verzocht. - De kostgrondjes zijn slordig en meestal klein. Er wordt o.m. rijst verbouwd. - Herhaaldelijk komt het voor dat de grond niet genoeg voedsel oplevert en de Djoeka zich daarom genoodzaakt ziet voedingsmiddelen op Albina in te slaan. - Op Drietabbetje worden de Blanken likeur en dram aangeboden.

Meestal heeft de Boslandcreool meer dan één vrouw, soms in één dorp, maar vaker in verschillende nederzettingen. De kinderen behoren de 
VOEDINGSGEWOONTEN VAN DE BOSLANDCREOOL 223

vrouw en haar familie toe. Misschien is dit een Afrikaanse gewoonte. Waarschijnlijker echter is het een overblijfsel uit de slaventijd, toen moeder en kind bij elkaar hoorden en niet gescheiden mochten worden verkocht.

Een obia zou o.m. geluk brengen op de jacht. Zelfs de hond krijgt zo'n voorwerp om de hals opdat hij het wild goed zal opsporen. Vruchtbomen worden ermee behangen ten einde veel te dragen.

Wijmans geeft in het werk van EILerTs de HaAN (I9ro) een samenvatting over de rijstbouw bij de Boslandcreool. - De man maakt een stuk van het bos geschikt ('koti gron') voor de 'prenasie' of kostgrond, doch de land- en tuinbouw worden door de vrouw uitgeoefend.

De rijst wordt in het begin van de grote regentijd (ongeveer in april) geplant en in het begin van de grote droge tijd (juli-augustus) geoogst. Op rotsen aan de oever of in de rivier worden de rijsthalmen gedroogd. In de 'mata' of vijzel wordt de rijst met de 'tatie' of stamper ontbolsterd en hierna op een 'patoe' of plat houten bord gezuiverd.

In het Koloniaal Verslag Suriname I911 wordt het aantal Aucaners geschat op 3700-4200, dat van de Paramaccaners op Ioo, Saramaccaners 2500, Bekoe's en Moesinga's of Matuari's 8oo.

Op de kostgrond worden rijst, aardvruchten en suikerriet (ter verkrijging van stroop) geteeld, terwijl jacht en visvangst het nodige voedsel van dierlijke aard opleveren. - Daar de aardvruchten niet lang op dezelfde grond gedijen, wordt bijna elk jaar een nieuw stuk land in gebruik genomen. Het vellen van het bos in de droge tijd (augustus tot november), het branden en voor zoveel doenlijk opruimen van het gevelde hout, kortom, het plantklaar maken van het land geschiedt door de man. Het eigenlijke planten is hoofdzakelijk het werk van de vrouw, die daarbij slechts nu en dan door de man wordt bijgestaan.

FLU (I9I2) beschrijft de woning van de Boslandcreool, welke 8-12 m lang, 5-8 m breed en enkele meters hoog is, en geheel uit hout en palmbladeren is opgetrokken. Alle vier opstaande zijden zijn totaal afgesloten op een lage deur na, aan elk van de smalle gevels. Ramen ontbreken. Een tussenschot verdeelt de hut in twee vertrekken, waarvan één wordt gebruikt als ziteetkamer en keuken, en het ander als slaapkamer. Bij het koken baant de rook zich een weg naar buiten door de spleten tussen de palmbladeren. Van binnen zijn de wanden dan ook roetzwart. De hut en het terrein eromheen worden zeer zindelijk gehouden. - Drinkwater wordt midden in de rivier geschept. De afwas wordt aan de oever gedaan. - De voorouders van de Boslandcreool, de vroegere Slaven, hebben veel van de hygiënische gebruiken en rituele voorschriften van hun meester, de Israëliet, overgenomen. - De kinderen nemen een kolossale hoeveelheid voedsel tot zich.

De Boslandcreool geeft aan vlekkenlepra de naam van 'trefoe'. Een treef zou elk voedingsmiddel zijn dat bij het voortgezet gebruik aanleiding zou geven tot het ontstaan van lepra. - Mijnwormziekte komt vooral onder de vrouwen voor, die zich met de landbouw bezighouden. 
Voullaire (1916) komt tot een aantal van I0.000-13.000 Boslandcreolen. Hun nederzettingen of dorpen tellen $200-400$ en meer inwoners. Zonder regelmaat breiden de palmbladhutten zich groepsgewijs in lange rijen uit. Tussen de huisjes staan palm- en vruchtbomen. - In de woningen is het opvallend schoon en zindelijk. Het voorvertrek wordt als woon- en eetkamer gebruikt. - De erfopvolging geschiedt in de vrouwelijke linie. De vader heeft niets te zeggen over de kinderen, wel echter de broeder van de moeder of van de grootmoeder. - Al de oude Afrikaanse gebruiken en voorstellingen herleven in de dorpen. Er zijn evenwel ook voorwerpen afkomstig van de beschaving, die zelfs tot diep in het binnenland hun weg vinden.

De levensbehoeften, voor zover de eigen geringe landbouw daarin niet voorziet, moeten door middel van lange, bezwaarlijke en dure boottochten uit Paramaribo worden aangevoerd. Daarbij kan er veel bederven, ja ook verloren gaan, vooral in de zo gevaarlijke stroomversnellingen. - De vrouwen en grotere kinderen werken in de tuinen. De mannen en oudere jongens vellen bomen, bewerken het hout, bouwen boten, jagen en vissen. - Als het dagwerk is volbracht, wordt er overal gekookt, gebraden en gegeten. In elk dorp wemelt het van kinderen die zich te goed doen aan hun met rijst gevulde kalebas. - Op een pijp zijn allen verzot; de oude vrouwen het allermeest. Ook wordt er gesnoven.

JUNKER (1944) haalt de volgende dagboekaantekeningen aan over een reis naar de Boven-Suriname in 1923.

In het begin van 1923 brengen de dagbladen weer eens berichten omtrent de hongersnood welke in het binnenland zou heersen. Tegelijkertijd komen van enige hoofden van de Boslandcreolen bij het Bestuur verzoeken binnen om verstrekking van levensmiddelen. De Gouverneur gevoelt evenwel niets voor een dergelijke steunverlening aan de bewoners van een vruchtbare landstreek, die bij minder zorgeloosheid best in hun eigen voeding hadden kunnen voorzien en die bovendien slechts een derde deel hebben afgelost van de schuld die in 1918 is ontstaan, toen het Gouvernement hun voor 25.000 gulden aan rijst had verschaft. Daarom wordt hem opgedragen na te gaan in hoeverre de geruchten omtrent hongersnood op waarheid berusten, en met het Groot-Opperhoofd van de Saramaccaners aan de Boven-Suriname de maatregelen te bespreken, welke in de toekomst het ontstaan van dergelijke situaties zouden kunnen voorkomen.

Hij constateert dat in de dorpen aan de beneden- en middenloop van de Suriname geen voorraden van voedsel aanwezig zijn en dat de kostgronden geheel uitgeplunderd zijn. In het zuidelijk gedeelte is de toestand wat beter: de kostgronden zijn er nog niet geheel geoogst en er is heel wat rijst aangeplant die op sommige plaatsen begint te rijpen. - Anderzijds leveren de awarrapalm en de koemboe gelukkig vele vruchten. De eerste bevat veel vet en wordt gewoon uit de hand gegeten of eerst tot een brij gestampt. Uit de tweede wordt een drank bereid die veel van cacao weg heeft.

Als hoofdoorzaken van het gebrek aan voedsel worden opgegeven: het slechte weer in de tweede helft van 1921 , de te vroeg ingevallen regens waardoor de afgekapte planten op de kostgronden niet in brand konden 
worden gestoken en de afwezigheid van een groot aantal mannen die in Frans Guyana zijn gaan werken.

In het dorp Voetoe-na-Kaba is de samenleving op communistische grondslag gebaseerd. Niemand bezit er enig eigendom. In een groot magazijn worden alle voor levensonderhoud benodigde artikelen opgeslagen. Voor het aankopen hiervan dienen de gezamenlijke inkomsten. Niemand mag zelf wat bezitten. Ook de kostakkers worden gemeenschappelijk aangelegd, beplant en geoogst. - Hij krijgt hier een kip en, uit de schildpaddenstal, een schildpad.

VANDERCOOK (1926) brengt over de Boslandcreool het volgende naar voren.

De vrouw bezit een keuken, dit is een grote hut zonder wanden. Hier zit zij de ganse dag haar kind te zogen, rijst te stampen en meel te bereiden. - De jongen wordt door zijn vader in de geheimen van de rivier en het bos ingewijd. - Het meisje wordt door haar moeder, tante en grootmoeder in de kunst van het koken, de huishouding enz. opgeleid.

Het dieet van de Boslandcreool is zeer beperkt. Van de geboorte af tot de dood makkt cassave $90 \%$ van zijn voedsel uit. Gelukkig groeit deze plant er snel en overvloedig. De cassavewortel wordt geschild en tot een meelachtige brij geraspt op de ruwe binnenvlakte van een uitgehold blok. De Saramaccaner perst deze brij uit in een lange uit riet gevlochten buis, die een sterke lus aan beide uiteinden heeft. De toplus wordt aan een boomtak gehangen. Door de bodemlus wordt een sterke stok gestoken waarop een robuuste man gaat zitten. Het giftige sap, dat bij innemen binnen een uur kan doden, wordt in een kom opgevangen. Het neerslag van het sap, tapioca, wordt door de Boslandcreool niet gebruikt. Op een ronde ijzeren plaat, die zich bevindt boven een vuur dat in een gat in de grond is gemaakt, worden uit het cassavemeel grote, ronde, dunne pannekoeken gebakken. Deze worden gedurende enige uren op een rieten dak in de zon te drogen gelegd, zijn dan houdbaar, en kunnen worden vervoerd. In water geweekt is de smaak ietwat wrang en melig. - Een tweede cassaverecept betreft een taaie brij met vlees, rijst, vis of wat verder ter beschikking staat. - Op het dorp groeien nog banaan en broodvrucht.

Glibberige riviervis wordt in fuiken gevangen. Een incidenteel met geweer of pijl neergeschoten hert of bosvarken met in Paramaribo aangeschafte rijst completeren het menu. Het is droevig gesteld met zulk een kost, maar omgekeerd heeft nog geen enkele boslandbewoner van de vloek van de weelde te lijden gehad.

De Surinaamse Boslandcreolen kunnen geen jagersvolk worden genoemd. Landbouw is steeds hun voornaamste bron van bestaan geweest. - De Boslandcreool heeft geleerd niet al te kieskeurig te zijn ten aanzien van zijn voeding en kan het een tijdje zonder eten stellen. Heeft hij op een korte reis geen voedsel bij zich, dan houden een paar bananen of snige cocosnoten hem wel verscheidene dagen op de been. Als hij te ig is haalt hij echter zijn schade in. - De Boslandcreool transpireert st $\mathrm{k}$ en drinkt ongelooflijk veel ongekookt water, afkomstig uit de zwarte zwamp, de gele rivier of de rode kreek. Thuis koelt hij het water in een aarden kruik.

De essentiële bezittingen van de Boslandcreool zijn: korjaal, pagaai, bank, roerspatel, cassavetrog, houten rijstvijzel enz. Zijn enige werk- 
tuigen om een roerspatel te maken zijn een zware bijl en een goedkoop zakmes. - Voor het vervaardigen van schep- en eetlepels en schalen uit kalebas wordt de rijpe vrucht voorzichtig in de zon gedroogd, opengemaakt, schoongekrabd en vervolgens in de verlangde vorm gesneden. Met een heet mes worden er dan figuren ingebrand. - Het enige voorwerp uit klei is de aarden koelkruik. - Uit gemak worden potten en messen van de Blanke gekocht. - De visval is een van de weinige artikelen die worden gevlochten.

Iedere Boslandcreool heeft een eigenaardig taboe, welk als een levenslang, algemeen offer wordt beschouwd, gewijd aan de boze geesten die zijn pad mochten kruisen, ten einde deze gunstig te stemmen. Dit wordt treef (een soort onthouding) genoemd en betreft een speciale handeling of een bepaald voedingsmiddel. Het laatstgenoemde, meestal vleesgebruik, komt het vaakst voor. Kort na de geboorte van een kind droomt een buur of familielid, meestentijds van het vrouwelijke geslacht, van een vreemde correlatie tussen het kind en zijn treef. De moeder wordt hiervan op de hoogte gesteld. Van dit moment af tot zijn dood toe mag de betrokkene de verboden spijs niet proeven, aanraken, ruiken, en, indien mogelijk, zelfs niet zien. Het offer is des te groter naarmate het ongemak en het verlangen sterker zijn. Een treefhandeling betreft b.v. het verbod gedurende een boottocht aan de wal te eten of tijdens het drinken te worden gezien. Dergelijke taboe's worden in bijna alle delen van Afrika eveneens aangetroffen. - Om de zeven dagen zal geen Djoeka of Aucaner op warmbloedig wild jagen. Op een andere dag mag hij niet vissen. Des zaterdags of zondags zal de Aucaner geen voedingsmiddel met bloed nuttigen. - De Boslandcreool drinkt geen water uit een reservoir. Hij giet het uit een kalebas of glas in ziin handpalm en drinkt het hieruit. - Hij zal niet eten uit een kookpot die niet door de medicijnman is gezegend.

StaAl (1928) bericht dat de Boslandcreool in zijn dagelijkse behoefte voorziet door jacht, visserij en landbouw. - Het is de vrouw die de kostgrond bewerkt. De man zorgt alleen voor het opruimen van het bos om de wisselgronden plantklaar te maken.

De verbouwde gewassen zijn gelijk aan die van de Indiaan, met dien verstande, dat bij de Boslandcreool de rijstbouw van oudsher bekend is. - Bij de visvangst wordt veelal gebruik gemaakt van een bedwelmend gif (nekoe) in een afgedamde kreek. Grotere vissen worden meestal met pijlen geschoten.

KAHN (193I) stelt onder meer een onderzoek in naar de voeding in het binnenland.

De Boslandcreolen vermaken zich over zijn tafelmanieren en maken opmerkingen over zijn voeding, waar zij hun neus voor ophalen als zij aan de lege blikjes ruiken. $\mathrm{Zij}$ geven de voorkeur aan hun eigen voeding, welke in de hut wordt bereid. - Zij zijn polygaam en matriarchaal. De sociale eenheid is de hut waarin de moeder met haar kinderen woont. - ' man bezit zoveel vrouwen hij maar verkiest. Deze vrouwen ge n vrij vriendelijk met elkaar om. Echtelijke jaloezie doet $z \quad h$ zelden voor. - Iedere vrouw woont afzonderlijk in een hut, die door haar man is gebouwd. Vaak staat deze in een ander dorp. Eveneens bezit iedere echtgenote haar eigen kostgrond, aangelegd door haar man, waar zij rijst en cassave verbouwt. 
Promiscuiteit komt zowel vóór als na het huwelijk algemeen voor. Overspel is iets gewoons. Het huwelijk is voor de Boslandcreool een zuiver economisch instituut. Het is bedoeld de man te voorzien van een kokkin en de vrouw van kinderen. Het gaat met weinig ceremonie gepaard. Niemand verzet zich ertegen, aangezien scheiding gemakkelijk is en dadelijk kan plaats vinden. - Echtscheiding geschiedt meestal op initiatief van de vrouw. De redenen hiertoe zijn: impotentie, die bij de man na het 35 e levensjaar vrij algemeen schijnt op te treden, onbekwaamheid in het jagen en vissen, tegenzin voor de man en liefde voor een andere. - Bij menstruatie zondert de vrouw zich af in een hut buiten het dorp. Pas drie dagen erna mag zij terugkomen. Tijdens deze periode begeeft zij zich niet naar het veld. - Een baby wordt gedurende drie maanden alleen maar gezoogd. Hierna krijgt hij cassave, waaraan gaandeweg rijst, vlees, ei en veel vruchten worden toegevoegd. Vaak wordt dit voedsel door de moeder voorgekauwd. Toch wordt daarbij de borstvoeding soms tot na het tweede levensjaar voortgezet.

De kunst van jagen, vissen en handwerk wordt de jongen gewoonlijk bijgebracht door zijn oom of een ander mannelijk familielid van moederszijde, en minder dikwijs door zijn eigen vader.

Op een afstand van een halve tot acht kilometer achter het dorp bevindt zich de kostgrond. Deze wordt door de vrouwen bewerkt en bestaat uit kavels van 0.2 hectare, aan het oerbos ontrukt door wekenlange harde arbeid met bijl en houwer. De bomen worden in stukken gehakt en verbrand of weggebracht. - De vrouwen worden bij de landarbeid slechts dan bijgestaan door de mannen, wanneer de gewassen worden bedreigd. - Als een bladsnijdende mier, de parasolmier, het op de cassavevelden heeft gemunt, rukken zij in twee parallelle colonnes op, éen naar het veld gaand en de andere hiervan terugkerend met stukjes bladeren. Ze leven van een schimmel die op het stukje blad groeit en zijn in staat een heel cassaveveld in betrekkelijk korte tijd te ontbladeren. - De kostgrond is niet erg vruchtbaar, omdat de aanhoudende stortbuien de humus uitlogen, terwijl het omzetten van de stikstofhoudende substanties in vruchtbaar materiaal meer tijd eist dan beschikbaar is. Vanwege de armoede van de grond en de constante bedreiging door insecten en vogels, is het cultiveren van voedingsgewassen moeilijk en zwaar, en moet de kostgrond telkens ergens anders worden aangelegd.

Het voornaamste landbouwproduct is de maniok of bittere cassave. De wortels bevatten blauwzuur dat met zorg moet worden verwijderd. De wortels worden voorzichtig geschild en tot een brij geraspt over het ruwe oppervlak van een hellende plank. Deze brij wordt dan in een cylindervormig, 5 voet lang, buigzaam vlechtwerk gedaan, matapi genoemd. Het boveneinde wordt aan een boomtak bevestigd; aan het ondereinde wordt een zware steen vastgemaakt waardoor de cylinder wordt uitgerekt en het giftige sap uit de inhoud wordt geperst. Men kan ook een stok door de lus aan het ondereinde steken, en er dan op gaan zitten. Van de gedroogde en gebakken pulp kunnen grote ronde koeken worden gemaakt, die zeer voedzaam zijn. Men weekt ze in rivierwater, of stooft ze met vis of vlees. - De techniek van het bereiden van cassavekoeken is overgenomen van de Indiaan. Matapi is een Indiaans woord.

In menig dorp komt koren voor, dat, wanneer het rijp is, wordt geroosterd totdat de maïskorrels zo hard als steen zijn. Als de Blanke vraagt 
om een onrijpe kolf, wordt hem gezegd dat deze niet goed is om te eten. - Een ander hoofdproduct is rijst, waarvan de hoogland-variëteit op droge grond wordt geplant. Deze rijst wordt gepeld in een houten vijzel waaromheen drie jongens staan, die beurtelings stampen. - Wanneer de rijst rijp is doen er zich vogels aan te goed, vooral parkieten en papegaaien. In één nacht kunnen deze wel een geheel veld vernietigen. Soms zijn de Boslandcreolen genoodzaakt de ganse nacht bij het veld te waken om de vogels met geweerschoten af te schrikken.-Plantenziekten komen er algemeen voor.

De Boslandcreool beschikt over bataat, bekend als yams. Koren, oker en pinda spelen een ondergeschikte rol in het diëet. Hij eet ook nu en dan banaan en cocos, alsmede ananas en de vrucht van de broodboom. Suikerriet wordt in menig dorp gezien. Enige noten en vruchten worden bovendien door het bos geleverd. - Palmolie, waarop de Boslandcreool dol is, wordt uit de maripanoot geperst. Geen reis wordt ondernomen zonder een ruime hoeveelheid van deze 'soft drink'.

Gejaagd wordt met een goedkoop geweer. Het in de winkel gekochte kruit heeft een te heftige uitwerking op het geweer, en wordt daarom vermengd met houtskool waaraan wat pimbadotie en wat droge nekoebladeren van de medicijnman worden toegevoegd. Het geweer wordt met wijn besprenkeld. Om de hals hangt de jager verscheidene amuletten: één om hem het wild te doen vinden, een andere om hem tegen verdwalen te behoeden en een derde om hem goed te laten mikken. Een hond vergezelt de Boslandcreool op de jacht. Bij het schieten rust de geweerkolf niet tegen de schouder, maar in de linker handpalm, op een armlengte van de jager. - Aan pijl en boog, die even algemeen zijn als het geweer, wordt door menigeen de voorkeur gegeven, omdat het gebruik ervan geen lawaai maakt. - De boog wordt uit letterhout of purperhart gemaakt en is bijna zes voet lang. De pees is van singrassi. De pijlen worden van hol riet vervaardigd en hebben een lengte van vijf voet. In een van de uiteinden wordt een houten of metalen punt geplaatst. Voor het jagen op vogels worden stompe pijlen gebezigd. - In noodgevallen wordt op de jacht soms van een houwer gebruik gemaakt. - Om het konijn te lokken wordt zijn roep nagebootst op een fluitje, gemaakt van klei of van een schelp. De imitatie is dermate natuurgetrouw dat soms een jaguar erop afkomt en de jager verrast. Voorts worden verschillende soorten vallen uitgezet die van Westafrikaanse oorsprong zijn. - De eenzaam dolende jager bouwt een schuurtje om er de nacht door te brengen en onderhoudt een vuurtje daarvoor.

Genuttigd worden onder andere: boskalkoen, boshen, rode brulaap, kwatta, tapir, pingo, pakira, miereneter, capasi enz. De boa en kaaiman worden niet gedood. Kop en staart van een gedode aap worden samengebonden, waarna de buit als een bastrompet over de schouder wordt geslagen. De aap wordt niet gevild; wel worden de haren afgekrabd. De huid is namelijk een lekkernij voor de Boslandcreool. De helft van het vlees gaat de pot in; de rest wordt gerookt.

De enige coöperatieve jacht is die op een tapir en een kudde pingo's (bosvarkens). Wanneer deze de rivier overzwemmen, achtervolgen de Boslandcreolen ze in korjalen, snijden ze de keel door, slaan ze op de kop, houden ze onder water enz. Het resultaat is een feest. De buit wordt verdeeld en het overtollige vlees gerookt. - Pluimvee wordt in menig dorp gehouden, maar men houdt geen runderen of varkens. 
VOEDINGSGEWOONTEN VAN DE BOSLANDCREOOL 229

Gevist wordt met pijl en boog. De punt van de pijl is door een touw aan de schacht verbonden, zodat hij, mocht hij afbreken, niet verloren gaat. - Een bepaalde vis, koemaroe, voedt zich met het zaad van de walaba die aan de oever groeit. De rijpe vrucht explodeert met een luide knal. Voor de vis is dit geluid geassocieerd met het vallen van het zaad in het water. Om de koemaroe te misleiden bootst de Boslandcreool de knal na met een klap van de hand, en wacht dan af met pijl en boog. - De vrouw legt soms een fles, waarvan de bodem is weggeslagen, met wat cassavekruimels in de hals op een ondiepe plek in het water bij de oever. Zodra er een vis inkomt pakt zij de fles uit het water. - Korven worden gemaakt van bamboe of riet. Ze hebben meestal een valdeurtje, maar er bestaan ook kegelvormige fuiken met borstels die gemakkelijk opzij schuiven bij het naar binnen zwemmen, maar de weg blokkeren bij het teruggaan. - De vraatzuchtige pireng komt vaak de vangst verstoren. Daarom wordt de lijn waaraan een haak zit, aan een mokomoko-plant bevestigd. De stengel wordt gebogen en zodanig onder water vastgemaakt, dat zodra een vis aan de haak trekt, de stengel zich opricht en de vis daardoor boven het water komt te hangen. - De pireng wordt door middel van een lijn met haak gevangen waarbij een stuk vlees als aas dient.

Als visvergif wordt nekoe gebruikt. Stukken van deze plant worden tot pulp geslagen en in het water geworpen, en de buit met een schepnet opgevist. - In de droge tijd gebeurt het dikwijls dat vissen worden geïsoleerd tussen zandbarrières, waar ze heel gemakkelijk met een schepnet kunnen worden opgehaald.

Het vissen geschiedt zowel door mannen, vrouwen, als kinderen. De vis wordt met peper gekookt en dan gegeten gelijk mais-aan-de-kolf. Vis. is een belangrijk onderdeel van het dieet.

De Boslandcreool snuift liever dan dat hij rookt. De tabaksbladeren worden geweekt in water, waaraan een beetje houtas wordt toegevoegd, en dan in een kalebasje of blikje bewaard. Het met de vingers uitgeknepen sap wordt in de handpalm opgevangen en vervolgens opgesnoven.

In Paramaribo schaft de Boslandcreool zich aan: kruit, lege hulzen, hagel, slaghoedjes, ijzeren gereedschap, een zigeuner-kookpot, tabak en zout. - Uit hout wordt allerlei keukengerei vervaardigd: dienblad, roerspatel, plank om pinda fijn te stampen enz. Borden en lepels worden uit kalebas gemaakt.

Steinberg (\& StaAL) (1933) tekenen aan dat het bos en de rivier vruchten wortels, wild en vissen opleveren. - De kostgiond (pranasie) die meestal niet vlak bij het dorp ligt en elk jaar weer elders wordt aangelegd, brengt rijst (z.g. bergrijst), pinda, suikerriet en aardvruchten, zoals cassave, nappie, yams en tayer voort. - Om in de overige behoeften te voorzien, moet de Boslandcreool werkzaamheden verrichten zoals: handel in hout, verzamelen van balata, en vervoer van personen en vracht over de rivieren. $\mathrm{Al}$ deze werkzaamheden noodzaken de man meestal maandenlang van huis te zijn.

De vrouw beschikt voor de keuken over ijzeren pannen, uit hout gesneden stampers en roerlepels, uit kalebas vervaardigde eetschalen en eetlepels, en voorts over Indiaanse kruiken. Tot de inventaris behoren verder nog: bosmes, houwer, bijl, geweer (voor de man), alsmede bogen en pijlen (voor de zoon). 
Het dorp wordt op de hoge oever van een rivier of op een eiland aangelegd. In tegenstelling tot het Indianendorp dat steeds op een zandgrond ligt, bevindt het dorp van de Boslandcreool zich vaak op kleigrond.

Goslings (1934) deelt mede dat de Boslandcreool leeft van jacht en visserij en van hetgeen zijn kostgrond hem oplevert. De hierop verbouwde gewassen zijn dezelfde als bij de Indiaan. Bovendien plant hij nog rijst, die met de cassave tot zijn hoofdvoedingsmiddelen behoort. - Zijn dorp is gebouwd op een opengekapt stuk bosterrein waarop evenwel een paar schaduw gevende bomen zijn gelaten en later nog enkele vruchtbomen worden bijgeplant. - Zijn drankzucht is even groot als die van de Indiaan. Tot zijn geluk kan hij echter lang niet zo gemakkelijk in het bezit van geestrijke dranken komen als de Benedenlandse Indiaan.

De LeEuW (1937) is de mening toegedaan dat de maatschappelijke eenheid de hut is, de geboorteplek van het gezin, waar de vrouw met haar kinderen huist. De leden van deze gezinnen behoren tot een béré; een aantal béré's vormen een lo.

Gewoonlijk liggen de dorpen niet ver van de rivieroever, soms wat meer het land in. - De woningen tellen meestal twee afdelingen; niet zelden bestaan zij echter slechts uit één kamer. Het dak bestaat uit riet. - Gekookt wordt in de hut. Soms is er een gemeenschappelijke keuken.

Bij de Boslandcreool wordt het matrilineale stelsel aangetroffen. De vader is slechts verantwoordelijk voor de ziel van zijn kinderen, terwijl de moeder het lichaam bijdraagt. De kinderen behoren tot de familie van de moeder. - De Boslandcreool is polygaam. Hij neemt zoveel vrouwen als hij kan bekostigen, dat wil zeggen dit aantal is even groot als het aantal hutten dat hij kan bouwen en inrichten. Iedere echtgenote woont in een afzonderlijke hut. Dikwijls heeft de man een eega in elk dorp. Een huwelijk wordt enkel gesloten om economische redenen. De vrouw heeft geen duidelijk begrip van huwelijkstrouw. $\mathrm{Zij}$ heeft het recht een scheiding aan te vragen. Reeds lang vóór het huwelijk heeft er geslachtelijke gemeenschap plaats, terwijl het vrije geslachtelijke verkeer na het huwelijk intensiever wordt. Wordt een vrouw op heterdaad op ontrouw betrapt, dan kan zij een danig pak ransel krijgen waaraan het gehele dorp deelneemt. Ook kan de zaak worden geregeld door de beledigde echtgenoot een schadevergoeding te geven. - Gedurende de menstruatie moet de vrouw zich in een hut buiten de grenzen van de béré afzonderen.

Tot de taken van de man behoren: vervaardigen van houten gebruiksvoorwerpen, jagen, vissen en opleiden van de jongen. Tot die van de vrouw : werken op het veld, bereiden van het voedsel, schoonmaken van het dorp en vissen. De jongen jaagt op vogels, vist en is behulpzaam bij het vervaardigen van houten gebruiksvoorwerpen. Het meisje stampt rijst, vist en helpt in de huishouding. - Het is de plicht van de vrouw toe te zien dat het dorp en het huis in een toestand verkeren overeenkomstig de sanitaire standaard van de Boslandcreool, die, tussen twee haakjes, uitstekend is. Er is geen spoor van vuil, afval of puin in het dorp te vinden. De grond wordt aangeveegd met bosjes twijgen. De tanden worden goed gereinigd. Overgebleven voedsel wordt aan de kippen gegeven. Vuilnis wordt buiten het dorp verbrand. Faeces wordt in kleine huisjes van bladeren buiten het dorp gedeponeerd. $\mathrm{Er}$ is geen meubilair om rommel te veroorzaken. 
VOEDINGSGEWOONTEN VAN DE BOSLANDCREOOL 23 I

De vrouw van de basja vervult de rol van ambtenares van de gezondheidsdienst.

De Boslandcreolen gevoelen zich volkomen thuis in de Surinaamse rimboe, daar deze hen sterk aan het Afrikaanse stamland herinnert. $\mathrm{Zij}$ keren geredelijk terug tot hun natuurlijke Afrikaanse gewoonten. Zij zijn stoer, gespierd en hebben een prachtig gebit.

In de hoofdstad wordt hout verkocht en kruit, zout en ijzeren werktuigen ingeslagen. - Aan geschenken ontvangen de Boslandcreolen tabak, alcoholische drank en chocolade. De kinderen bedelen om méér hiervan.

Het voedsel wordt bereid door: bakken, koken, braden, stoven en barbakotten van vlees en vis. - De gebruiksvoorwerpen van hout zijn: vijzel, waarin door vrouwen of meisjes rijst, koren of cassaveperskoeken worden gestampt, cassaverasp, versierde houten lepel en stok voor de cassavepers. Dan heeft men nog: eetschaal en houder van kalebas, cassavepers van bamboe, mand, zeef en ijzeren of stenen cassavebakplaat.

De hulpmiddelen bij de jacht zijn: geweer, kruit, pijl en boog, volgen van het spoor en het verdrinken van pingo's. Die bij de visvangst zijn: pijl en boog (bij de stroomversnellingen), harpoen, schepnet, lokgeluid, visvergif, knots (om nekoe te kneuzen), en korjaal (om de gekneusde nekoe in te vervoeren). Als de peul van de walaba met een luide plof openspringt, komt de koemaroe erop af om de zaden op te peuzelen. De listige Djoeka bootst dit geluid na door in de handen te klappen. De vis wordt dan opgeschept of geharpoeneerd.

$\mathrm{Bij}$ een grote visvangst wordt de gehele mannelijke bevolking uitgezonden om nekoe te verzamelen. De omliggende dorpen worden opgeroepen om hulp te komen verlenen. Aan deze vispartij nemen mannen, vrouwen en kinderen actief deel. - De nekoe wordt met stokken geslagen, met water aangelengd en gestampt tot een melkachtig sap dat sterk alkalische eigenschappen bezit, en daarna in korjalen gegoten die langzaam naar diep water worden geroeid. Dan wordt de boot omgekeerd. Spoedig kan dan de vis, die met de buik naar boven komt drijven, worden opgeschept met vaardig geweven visnetten. Aldus worden gedurende enige uren duizenden vissen gevangen en naar de wal gebracht waar men ze braadt of rookt.

$\mathrm{Er}$ is een grote afwisseling van vleessoorten, zoals pingo, pakira, tapir, wild konijn, boskalkoen en van allerlei vissoorten. Apenhuid is een grote traktatie. De slang daarentegen is heilig, terwijl ook de kaaiman niet mag worden gekwetst. - Vis vormt een belangrijk onderdeel van het voedsel van de Djoeka. Het dier wordt in zijn geheel gekookt en dan van de kop tot de staart gegeten, zo ongeveer als een Hollandse visser zijn bokking of zoute haring eet, of een Amerikaan zijn maïskolf. - Soms worden ook schildpadeieren verzameld. Hieruit wordt olie bereid, die bij het koken wordt gebruikt of wordt opgediend in plaats van boter. De olie wordt in kalebassen bewaard.

De bosgrond is niet vruchtbaar, aangezien de voortdurende tropische regens de humusvorming belemmeren. In hoofdzaak gedijen er slechts knolachtige gewassen. - Het hoofdproduct van de Djoeka is cassave. Het tweede hoofdproduct is rijst, een variëteit uit het hoogland, die op de droge bodem wordt geplant. Voorts worden gebruikt: koren, bataat, banaan, broodvrucht, pinda, cocos, ananas, suikerriet en kouseband. Het allervoornaamste is maripapalmolie. 
De cassavewortel wordt, na geschild te zijn, op scherpkantige planken tot pap gestampt. Dan wordt de massa in een matapi gedaan en uitgeperst zodat het giftige sap, dat Pruisisch zuur bevat, er uitzweet. Het uitpersen wordt bewerkstelligd door de matapi aan een lage balk te hangen en een stok door de onderste lus te steken waarop een paar zware vrouwen gaan zitten. Het sap wordt in een kalebas opgevangen. De harde cylindervormige kern wordt in een houten vijzel gestampt en dan door een tenen zeef gezift. Het aldus verkregen fijne meel wordt vervolgens met water bevochtigd en geplet tot een deeg, dat op een warme steen of ijzeren plaat boven een vuur wordt gebakken. De harde, ronde broden worden op een raam van stokken in de zon gedroogd. Voordat men de taaie korst ervan eet, bevochtigt men deze eerst met rivierwater. - Bij koken verdampt het Pruisisch gif uit het uitgeperste cassavesap. De nu onschuldige vloeistof wordt in kalebassen bewaard en vormt een uitstekende drank. Ook wordt hieruit een ragout, de beroemde peperpot van Guyana bereid. Deze saus maakt niet alleen het vlees mals, maar is ook bederfwerend.

$\mathrm{Bij}$ het maken van een korjaal wordt een rondje rum gegeven. - De vrouwen zijn verwoede rooksters, terwijl de mannen aan het pruimen van tabak de voorkeur geven.

VAN DER KUYP (1939) vindt dat de voeding van de Boslandcreool in de omgeving van Koffiekamp, Kabel en Ganzee eenzijdig is en een overmaat van koolhydraten bevat. Het voedsel bestaat hoofdzakelijk uit rijst en cassavebrood. Soms wordt hieraan vis of wild toegevoegd. Af en toe worden gebruikt: kip, nappie, yams, bataat, banaan, tayer, tayerblad, suikerriet, pinda, bacove, sinaasappel, maripa, awarra, koemboe en cocosnoot. Vet wordt uit palmpitten bereid. - De Boslancreool plant juist voldoende voor zichzelf en zijn gezin. Kort tevoren is de rijstoogst op Ganzee mislukt. Er heeft dan ook pas hongersnood plaats gevonden. - Zieken, of personen op reis die een week onvoldoende eten, vertonen

Gemiddelde haemoglobinegehalte, Boslandcreolen, Boven-Suriname; juli, resp. nov. 1939

\begin{tabular}{|c|c|c|c|}
\hline \multirow[t]{2}{*}{ Leeftijdsgroep } & \multirow{2}{*}{$\begin{array}{c}\text { Aantal } \\
\text { onderzocht }\end{array}$} & \multicolumn{2}{|c|}{ Haemoglobinegehalte } \\
\hline & & gemiddeld & variatiebreedte \\
\hline o & 29 & 45 & $25-60$ \\
\hline$I-5$ & 167 & 51 & $40-60$ \\
\hline 6-10 & 131 & 53 & $40-70$ \\
\hline II $-I_{4}$ & II5 & 55 & $50-70$ \\
\hline $1_{5}+$ (mannelijk) & I5 & 54 & $45-60$ \\
\hline$I_{5}+$ (vrouwelijk) & 93 & 54 & $45-60$ \\
\hline o & I7 & 44 & $30-55$ \\
\hline $\mathbf{I}-5$ & 66 & 51 & $35-60$ \\
\hline $6-10$ & 108 & 55 & $45-60$ \\
\hline II-I4 & 91 & 56 & $40-65$ \\
\hline $\mathbf{I}_{5}+$ (mannelijk) & III & $5^{8}$ & $45-90$ \\
\hline $\mathbf{r}_{5}+$ (vrouwelijk) & 107 & 55 & $30-80$ \\
\hline
\end{tabular}


VOEDINGSGEWOONTEN VAN DE BOSLANDCREOOL 233

beri-beri. - Als genotmiddelen worden dram en tabak gebruikt. De tabak wordt gerookt of in water gestopt en het uitgeperste sap kort vóor het slapen gaan, opgesnoven.

De woningen bestaan meestal uit twee kamers en tellen twee deuren, maar geen vensters. In deze slecht geventileerde huizen wordt het voedsel op een houtvuur bereid.

In Ganzee worden ${ }^{156}$ schoolkinderen van 6-I4 jaar onderzocht. $\mathrm{Bij}$ rog $(70 \%)$ wordt avitaminose vastgesteld en bij $39(25 \%)$ opvallende magerte. In Koffiekamp komen onder 50 schoolkinderen van 4-15 jaar voor: 50 gevallen van avitaminose (100\%) en 24 van opvallende magerte $(48 \%)$. De avitaminose betreft overwegend het B-complex. - De hierbij afgedrukte tabel vermeldt het gemiddelde haemoglobine-gehalte volgens de methode van Tallquist bij $55^{\circ}$ en 500 Boslandcreolen in juli resp. november 1939 onderzocht.

VAN Lynden (1939) krijgt van Boslandcreolen aan de Tapanahoni: eieren, bataat, ananas, banaan en bacove.

Hiss (1943) meldt dat er soms een stookplaats in een hoek van de voorkamer van de twee vertrekken tellende hut van de Boslandcreool wordt aangelegd. Er is evenwel geen opening in het dak waar de rook kan ontsnappen. Soms wordt gekookt in een gemeenschappelijke hut die als keuken dient.

De Boslandcreool leeft van de jacht, visserij en landbouw. Hij jaagt met pijl en boog en wanneer mogelijk met een geweer. Hij vist met behulp van pijl en boog, een lijn, een gif (nekoe) of een fuik. - Landbouw in het binnenland is moeilijk. De grond is daar niet erg vruchtbaar, aangezien het regenwater er de mineralen uitloogt. De Boslandcreool kweekt yams, bittere cassave, pinda, maïs, droge rijst en een beetje suikerriet. - De producten op de kostgrond worden vaak aangetast door de parasolmier. Dit komt omdat de Boslandcreool zijn nieuwe kostgrond naast de oude aanlegt, in tegenstelling met de Indiaan die een nieuwe plek ver van de oude kiest. Door de roofbouw komen de gronden steeds verder van het dorp te liggen (ro-15 $\mathrm{km}$ ).

MALMBerg \& LABAdie (I944) rapporteren dat de zoogperiode bij de Boslandcreool aan de Boven-Marowijne twee jaren duurt. Hoe verkeerd zulk een gewoonte ook moge zijn, deze heeft toch praktisch nut, want het aantal beschikbare gerechten geschikt als zuigelingenvoedsel, is gering en onvolwaardig. Na deze twee jaren volgt een korte periode van zachte voeding met onder meer cassavemeelpap, kwak met suiker en water, alsook soep. Reeds op drie- tot vierjarige leeftijd nuttigen de kinderen het menu van de volwassene.

$\mathrm{Zij}$ delen op de volgende wijze (iets veranderd door de schrijver) de levensmiddelen van de Boslandcreool aan de Boven-Marowijne in. 1. Hoofdvoedsel. - Rijst. Cassave: zoete, domi (meel van bittere). Andere aardvruchten: dasjien, nappie, bataat. Rijpe banaan. 2. Toespijs. - Vlees : vers, gedroogd, gezouten. Vis: vers, gedroogd of gezouten. Groente (oker) 3. Andere spijzen. - Vruchten. Vetten: cocosolie, maripa-olie. Suiker en suikerriet. Zout.

Rijst, aan de kust ingeslagen of tegen de heuvels op de kostgronden 
door de vrouw verbouwd, wordt zolang de voorraad strekt driemaal 's daags in enorme hoeveelheid gebruikt. - Zoete cassave, gekookt of in soep verwerkt, wordt weinig genuttigd. - Van bittere cassave wordt cassavemeel of domi gemaakt, dat dient voor de bereiding van diverse voedingsmiddelen zoals: cassavebrood, kwak (genuttigd met water en veel suiker), domiballetjes in soep, pannekoeken, en domipap als kindervoedsel. - Bij gebrek aan rijst nemen cassavebrood en kwak (twee koude gerechten) de plaats daarvan in, of anders dasjien (een tayersoort die meestal in soep wordt verwerkt en zelden gewoon gekookt). - Nappie wordt minder vaak gebruikt; bataat en rijpe banaan een enkele maal. - Peulvruchten worden niet geconsumeerd.

Beschikt de Boslandcreool over geld, dan kan hij gezouten vlees, gedroogde vis en bakkeljauw in een van de talrijke Chinese winkels langs de Marowijne kopen. Gewoonlijk heeft hij evenwel geen geld. Dan moet hij zijn eiwitbehoefte door jacht en visvangst dekken. - Door gebrek aan goed afgerichte jachthonden is de jacht erg achteruitgegaan. De Boslandcreool koopt namelijk zijn jachthonden van de Trio Indiaan die deze weer verkrijgt van de Saloema, een Braziliaanse Indiaan. Deze twee stammen leven echter al jaren in onmin.

De visvangst geschiedt door: hengelen door de vrouw; duiken door de vrouw (de man doet dit ook tijdens de vrachtvaart); schieten met pijl en boog in de vallen; massaal vergiftigen met de wortels van nekoe; vergiftigen met bogo (koenami).

Nekoe is een liaan, die door het stelselmatig afkappen aan de Marowijne vrij zeldzaam is geworden. De stukken wortel worden fijngeslagen. Het melkachtige sap dat vrijkomt wordt in de rivier over de gehele breedte of in een gedeelte tussen twee eilanden gedaan (z.g. ponsen). De vissen raken bedwelmd en komen dan aan de oppervlakte. Op deze wijze worden op één dag soms duizenden vissen gevangen. - Bogo is een zwartgroene, aromatisch riekende, stopverfachtige massa, bereid door koenamibladeren met in water geweekt cassavebrood tot een homogeen geheel te kneden. Stukjes hiervan in water gegooid bedwelmen de vissen die ervan eten, waarop ze aan de oppervlakte komen. - Overgebleven vis en vlees worden op houten stellages gedurende enige dagen in de zon gedroogd, waardoor ze al gauw gaan stinken.

De enige groentesoort die wordt gebruikt is de oker. Elke lepel rijst wordt even in okersoep gedompeld, zodat alleen het nat van de soep, maar niet de oker zelf wordt genuttigd. Volgens zeggen zou de Boslandcreool ook tayerblad gebruiken. - Bacove wordt vrij veel gegeten, cocosnoot wat minder. Manje, casjoe, awarra, maripa, sterappel en gujave worden soms genuttigd.

Het vetgebruik is zeer gering: cocosolie en minder vaak maripaolie worden alleen gebruikt bij het bakken van pannekoek en vis. - Het suikergebruik is zeer hoog. Suiker wordt in grote hoeveelheid met kwak verorberd. Op suikerriet is de Boslandcreool zeer gesteld. Het zoutgebruik is matig.

De eerstvolgende tabel geeft een overzicht over de voedingstoestand van de kinderen. Slechts van ro kinderen tussen 2-15 jaar zou kunnen worden gezegd dat zij echt ondervoed zijn. Vier van hen lijden aan framboesia tropica. - De avitaminosen worden vastgesteld op grond van de volgende verschijnselen die soms aanvechtbaar zijn. Avitaminose A: 
VOEDINGSGEWOONTEN VAN DE BOSLANDCREOOL 235

keratosis pilaris, hypertrofische papillen, nachtblindheid, bruine sclera, vlekken van Bitot (zeldzaam). Avitaminose $\mathbf{B}_{2}$ : perlèche, gladde tong, circumcorneale vaatinjectie, scrotale dermatitis, perlèche van de penis. Avitaminose $B_{6}$ : huid- en tongverschijnselen, diarrhoea. Avitaminose $C$ : tandvleesbloeding. Avitaminose D: voelbare rozenkrans. - Van 615 onderzochte personen die zich op het spreekuur melden lijden 5,5\% aan avitaminose A, 6,8\% aan avitaminose $B_{1}$ en $r_{5}, 5 \%$ aan avitaminose $B_{2}$.

De volgende twee tabellen geven het haemoglobinegehalte (onderzocht volgens de methode van Tallquist) weer.

Onder 379 volwassenen die zich op het spreekuur aanmelden hebben 304 een te laag haemoglobinegehalte. Van I67 vrouwen hebben 6 minder dan $60 \%$, 6 minder dan $40 \%$ en één minder dan $20 \%$. - Alhoewel onvolwaardige voeding en ancylostomiasis een rol spelen, moet de malaria toch als belangrijkst aetiologisch moment van de anaemie worden beschouwd.

Voedingstoestand, Boslandcreoolse kinderen, Boven-Marowijne (gemodificeerd)

\begin{tabular}{lrr}
\hline \multicolumn{1}{c}{ Aantal } & Beneden 2 jaar & 2-15 jaar \\
\hline onderzocht & 22 & \multicolumn{1}{c}{396} \\
met ondergewicht & $2=9 \%$ & $22=6 \%$. \\
met onvoldoende turgor & $2=9 \%$ & $49=12 \%$ \\
met droge huid & $3=14 \%$ & $\mathbf{1 1 3}=\mathbf{2 9} \%$ \\
met avitaminose A & $\mathbf{1}=5 \%$ & $\mathbf{1 2 1}=3 \mathbf{1} \%$ \\
met avitaminose $\mathrm{B}_{2}$ & $2=9 \%$ & $\mathbf{1 2 4}=3 \mathbf{1} \%$ \\
met avitaminose $\mathrm{B}_{6}$ & & $2=0.5 \%$ \\
met avitaminose C & & $\mathbf{1}=0.3 \%$ \\
met avitaminose D & $7=32 \%$ & $50=13 \%$ \\
\hline
\end{tabular}

Haemoglobinegehalte, Boslandcreolen, Boven-Marowijne (gemodificeerd)

\begin{tabular}{|c|c|c|c|c|c|}
\hline \multirow[t]{2}{*}{ Leeftijdsgroep } & \multirow[b]{2}{*}{$<40$} & \multicolumn{3}{|c|}{ Haemoglobinegehalte } & \multirow[t]{2}{*}{ Totaal } \\
\hline & & $4^{0}-59$ & $60-84$ & $85-100$ & \\
\hline o & & 6 & 5 & & II \\
\hline$I-I 4$ & 12 & 207 & 172 & 4 & 395 \\
\hline $1_{5}+$ (mannen) & & 36 & II9 & 2 & I57 \\
\hline $\mathbf{r}_{5}+$ (vrouwen) & 2 & 63 & 152 & 2 & 219 \\
\hline grijsaards & & 2 & 4 & & 6 \\
\hline
\end{tabular}


Haemoglobinegehalte, malaria en ancylostomiasis, Boslandcreolen, Boven-Marowijne (gemodificeerd)

\begin{tabular}{lccc}
\hline Leeftijdsgroep & $\begin{array}{c}\text { Gemiddeld } \\
\text { haemoglobinegehalte }\end{array}$ & $\begin{array}{c}\text { Miltindex } \\
(\%)\end{array}$ & $\begin{array}{c}\text { Ancylos- } \\
\text { tomiasis }\end{array}$ \\
\hline o & 57 & $7 \mathbf{1}$ & \\
I-4 & 53 & 77 & \\
$5-9$ & 55 & 52 & \\
10-14 & 60 & 22 & \\
15 + & 62 & 1.6 & + \\
2-14 & 57 & & + \\
15 & 64 & & - \\
I5 & 63 & & \\
\hline
\end{tabular}

Stahel (1944) somt de nuttige planten op die de Boslandcreolen gebruiken en noemt ze bij hun wetenschappelijke namen.

Gogomango is een sappige groente die bij voorkeur op vers opengekapte lichte, binnenlandse gronden groeit, soms in zeer grote hoeveelheden. De Boslandcreool eet evenwel weinig of geen groente. Vandaar dat hij dikwijls aan vitaminegebrek lijdt. - Gobogobo of bosnegerpinda lijkt op pinda, maar bevat veel zetmeel en weinig olie. De peulen worden volgens Afrikaanse gewoonten gebakken, soms ook gekookt als bonen. - Algemeen wordt maiis als eerste gewas op pas aangelegde bosgrond geplant. - Rijst wordi door de Boslandcreool op vers opengekapte bosgronden gecultiveerd. Het zijn meestal viermaandse soorten (bosnegerrijst, witte wanica en bruinmissie) en de vijfmaandse rexora. - De zaden van wanja, een soort sesam of abongra, worden in okersoep gedaan of in fijngestampte vorm in cassavepap. - Cassave is het belangrijkste zetmeel bevattende voedselgewas voor de bewoners van het binnenland. De grote cassaveknollen bevatten onder meer een glucoside dat gemakkelijk het giftige blauwzuur afsplitst. Er worden twee soorten cassave onderscheiden: de bittere en de zoete. De eerste bevat zoveel van het gif dat het gebruik ervan dodelijk is. In zoete cassave is dit gif slechts in geringe hoeveelheid aanwezig en wel voornamelijk in de schil. Ten einde de bittere cassave voor consumptie geschikt te maken worden de knollen geraspt en in een matapi uitgeperst. Met het wegstromende sap wordt het overgrote deel van het gif verwijderd. De cassave-perskoeken worden fijngewreven en op een hete ijzeren bakplaat gestrooid. Tijdens het bakken wordt het brood met behulp van een vuurwaaier enkele keren omgedraaid om het gelijkmatig te laten doorbakken. Deze platte, slechts één $\mathrm{cm}$ dikke en ${ }^{30-40}$ $\mathrm{cm}$ brede broden worden meestal nog gedurende enkele dagen op het strodak in de zon geplaatst om ze grondig te laten uitluchten en drogen waarna ze vele maanden houdbaar zijn. Om een alcoholische drank (tapana van de Boslandcreool) te bereiden, worden stukjes cassavebrood met weinig water gedurende drie dagen gegist. Deze gistende massa wordt in een grote hoeveelheid suikerrietsap gebracht. Het cassavebrood dient -dus slechts om de gisting van het suikerrietsap op gang te brengen. - 
Amana is een soort awarra in de Boven-Suriname. Deze palm met grote ronde oranje vruchten, is uit Frans Guyana afkomstig.

De volgende bosvruchten worden door de Boslandcreool gegeten: bosmarmeldoos, bosmispel, mispel, locus, switibontji of plokoni, balatavrucht, koemboe, pina, maripa, awarra, mauritius, bambamaka, keskesimaka, kaumaka, doeka, pera of amapa, sokosoko, tingimoni of hajawa, sali, basterd bolletrie of bakabé, savanna kwarie, boroma, kwattabobi of laurierskers, kimboto of kodibiosi, lagosofoeta of kodibiosiballi, malobi of bataballi, riemhout, en Jan Snijder.

De Boslandcreool heeft van de Indiaan, maar ook van de kwatta-aap geleerd welke bosvruchten eetbaar zijn. - Hij heeft meestal een busje met natte tabak bij zich. De uitgeknepen vloeistof wordt opgesnoven. De oude vrouw rookt daarentegen gaarne de tabak, meestal uit een pijp met korte steel die zij zelf uit klei heeft vervaardigd. - Van bladeren van granjaba maakt hij een soort thee klaar.

Uit verscheidene palmpitten wordt olie bereid: maripa, Afrikaanse obé (op Santigron) en toekoemau. De noten worden in de zon gedroogd en dan gekraakt. De pitten worden in een vijzel tot moes gestampt. Dit moes wordt in water gekookt waarna de drijvende olie wordt afgeschept.

Wanneer de Boslandcreolen van plan zijn een ponsoe, dat wil zeggen een grote visvangst te ondernemen, dan wordt door de bewoners een grote hoeveelheid nekoewortels bijeengebracht. Met een knots worden de wortels op een rots in de rivier fijngeslagen. De gekneusde massa wordt in water, in een pot of korjaal, grondig uitgeloogd. Het melkachtige vocht wordt ineens in de kreek of rivier gedeponeerd. De vissen worden dan bedwelmd en komen aan de oppervlakte, waar ze gemakkelijk kunnen worden gevangen. Vanwege het gebruik van nekoe op grote schaal is de visrijkdom in de rivieren waarlangs Boslandcreolen wonen, sterk afgenomen.

De hooglandparasolmier kan, in groepsverband, in één nacht een grote boom kaal maken. Op de stukken blad, die naar de onderaardse kamers van het nest worden gebracht, groeit een schimmel, waarvan de vruchtlichaampjes het enige voedsel van deze mier uitmaken. Deze hooglandparasolmier komt alleen daar voor, waar de grondwaterspiegel enkele meters beneden de oppervlakte ligt.

Uit de vrucht van de kalebas maakt de Boslandcreool waterkruiken, kommen en lepels. Met een mes worden versieringen erop aangebracht. Ook van de fleskalebas worden waterkruiken vervaardigd.

De pees van de boog bestaat uit vezels van de singrassi. - De binnenbast van zeephout, die saponine bevat, dient als zeep. - Met warimbomerg pleegt de vrouw potten en pannen te schuren. Soms worden ook de afgedorste rijstaren hiervoor gebruikt. - Als bezem wordt de prasara (de vrucht- of bloemtros van de pinapalm) gebruikt, nadat alle vruchten of bloemen verwijderd zijn. Andere bezems bestaan uit rijststro, mandoendoegras en kaminarepen. Reeds vroeg in de morgen is de vrouw bezig haar erf schoon te vegen.

Arkieman (1945) ziet een groep vrouwen rijst stampen en anderen cassavemeel in biezen manden zeven, terwijl een derde groep platte cassavebroden bakt. Mannen dragen een tapir aan een boomtak het dorp binnen. - Voor een feest worden rijst, tapirs, pingo's, apen en gevogelte bestemd. 
Ook wordt daartoe een grote hoeveelheid bier gebrouwen in uitgeholde boomstammen. - Door een oude Boslandcreoolse wordt aan een verdwaalde Blanke cocossap, cassavekoek en bosvruchten aangeboden.

SAUSSE (195I) maakt van 1948-1949 een tocht naar de Boven-Marowijne. Zijn bevindingen over de Boni luiden als volgt:

Er zijn verscheidene Franse Boni-dorpen en éen Surinaamse Boni-nederzetting, Cottica genaamd. - De samenleving berust op het principe van de hiërarchie. - De sociale eenheid wordt gevormd door de moeder en haar kinderen. De vader is geen lid van de familie. Hij bemoeit zich niet met de opvoeding van zijn kroost. Hiermede is de broer van de moeder belast. De naaste bloedverwanten van een man zijn dus zijn moeder, broer en zuster, alsook de kinderen van laatstgenoemde. De Boni huldigt derhalve het matrilineale stelsel. - Het huwelijk is niet gekenmerkt door ceremonieel. Het heeft het karakter van een associatie. Man en vrouw wonen afzonderlijk. De man ontgint voor de vrouw een stuk land in het bos; zij zorgt voor het beplanten en oogsten. Hij maakt houten voorwerpen; zij bereidt het eten. - De vrouw is geen slavin van de man. $\mathrm{Zij}$ is niet gekocht of tegen haar zin in getrouwd.

Polygamie is iets gewoons en natuurlijks. Als een man daartoe de middelen bezit, belet niets hem méér vrouwen te hebben. $\mathrm{Er}$ is natuurlijk een beperking; de man is namelijk verplicht verschillende velden aan te leggen en zijn gezinnen te voorzien, want iedere vrouw woont in haar eigen huis. Daarom kan de Boni het zich niet veroorloven meer dan drie vrouwen te onderhouden. Dit systeem bevordert een excessief individualisme. Scheiding is eveneens gewoon. Wanneer de man en vrouw het niet langer met elkaar eens zijn, wordt de verbintenis verbroken zonder enige schadeloosstelling. De kinderen blijven het eigendom van de moeder en haar familie.

De Boni cultiveert de gewassen in wanorde en zonder bijzondere zorg. Hij pleegt roofbouw. De bomen worden geveld, gedroogd en verbrand. Het veld wordt beplant. $\mathrm{Na}$ een jaar keert de vrouw terug om te oogsten. Het daaropvolgende jaar wordt de kostgrond elders aangelegd. De gronden liggen hierna gedurende vijftien jaren braak. - De essentiële voedingsmiddelen zijn cassave, yams, rijst en banaan. Soms worden ook pinda en gember geteeld. In het dorp zijn er nog wat vruchtbomen: cacao, cocos en citroen. De laatstgenoemde wordt alleen gebruikt voor het schoonmaken van het keukengerei.

Het voedsel is over het algemeen gezond en in overvloed aanwezig. Maniok, in de vorm van kwak en cassave, maakt meer dan de helft, soms zelfs tweederde deel uit van het voedsel. Dan volgen yams en dasjien, vervolgens rijst. Banaan, hoofdzakelijk gebakken, dient als bescheiden aanvulling. Van koemboepitten wordt een brij gemaakt die zeer in de smaak valt. - Het dierlijk voedsel varieert zeer al naar gelang het seizoen. $\mathrm{Er}$ is steeds een beetje vis, dat de vrouw met de lijn of fuik vangt, maar zelden vlees. Af en toe wordt een kudde pingo's op de rivier afgeslacht. Het gehele dorp smult er dan dagenlang van. - De vis wordt volgens de Indiaanse methode met peper toebereid of gerookt. Vlees wordt gekookt of gerookt. - Zout, olie, suiker alsook tafia en soms meel, cacao en zelfs 'corned beef' worden geïmporteerd.

De Boni heeft de povere voeding van zijn voorouders gehandhaafd. 
VOEDINGSGEWOONTEN VAN DE BOSLANDCREOOL 239

Hij geeft de voorkeur aan een gekookte brij, of een compacte, eenvoudig gekruide kost. Er is slechts één woord in zijn taal om de spijs aan te duiden, namelijk 'boilli' (gekookt). - De voeding is zeer voldoende wat betreft de energie, maar weinig gevarieerd en slecht verteerbaar. Daarenboven is er een tekort aan mineralen en vitamine $C$.

De Boni eet niet begerig, zelfs niet wanneer er veel voedsel is. Hij vermorst geen eten, en is verplicht wat opzij te leggen. - Hij bezit ingevoerde ijzeren potten en lepels, maar toch zijn de traditionele, kleine, van binnen versierde kalebassen en kalebaslepels algemeen in gebruik.

De meeste Boni's, en vooral de jongeren, zijn zonder meer onderworpen aan de naleving van bepaalde taboe's, waarvan de betekenis hun niet wordt uiteengezet. - Er zijn drie soorten taboe's, die, welke gelden voor het individu, de gehele familie, en de gehele stam. Het taboe voor de gehele familie berust meestal op een voorval. Heeft bijv. een voorzaat een avontuur beleefd met een bepaald dier, dan mag dit dier noch worden gedood, noch gegeten door de nazaten. Een voedingsmiddel dat een grootouder heeft ziek gemaakt, wordt voor de familie taboe.

DE Groot (1953) wijst erop, dat de bereiding van voedsel op zorgzame en zindelijke wijze door de vrouw geschiedt. $\mathrm{Zij}$ staat bekend als een voortreffelijk kokkin. - Op een groot houten bord worden de lepels alsmede de verschillende met spijzen gevulde schalen, kommen en kalebassen gerangschikt. - Met zand en een bosje rijststro worden potten en pannen geschuurd. Ook de kalebassen en lepels worden met zorg schoongemaakt. - Na de maaltijd worden de tanden met een vinger schoongepoetst en de mond goed uitgespoeld. De etiquette brengt mee dat bij het eten luid wordt gesmakt en erna geboerd. De vrouw eet met haar kleine kinderen apart. Wordt de zoon groter, dan zit hij met zijn vader aan. De dochter nuttigt de maaltijd altijd samen met de moeder.

Als wapens zijn in gebruik: geweer, houwer, pijl en boog. De hartstocht voor de jacht is de Boslandcreool aangeboren. Handig wordt met een houwer de buit gestroopt en ontleed, en de bouten in palmbladeren gewikkeld. - Het vissen geschiedt onder andere met pijl en boog. Aan de Marowijne wordt de koemaroe die zeer smakelijk is, door middel van walaba-palmpitten gelokt. Deze pitten worden in stukjes gehakt en zonder met de hand te zijn aangeraakt in een gevlochten palmbladkorfje geplaatst. Een liaan die aan het korfje is gebonden, wordt aan een takje bevestigd. Door met de hand op de dij te klappen wordt het kletsend geluid van de openspringende walabanoot geïmiteerd en tegelijk werpt men het korfje in het water. Met pijl en boog wordt dan de toeschietende vis verschalkt.

De bodem is in het algemeen niet zo geschikt voor de landbouw, al schijnt die stroomopwaarts beter te worden. Mede door droogte en parasolmieren, die te velde staande rijst in éen nacht tijds kunnen vernietigen, is hongersnood een veelvuldig rondwarend spook in het binnenland. Individuele ondervoeding en beri-beri doen zich nogal eens voor. Aan de Marowijne is de voedingstoestand beter dan aan de Boven-Suriname. - De samenstelling van het voedsel (met veel suiker, weinig vet en een groot gebrek aan eiwit en vitaminen) is geheel onvoldoende. Groene groenten worden weinig gebruikt, vruchten evenmin.

Het hoofdvoedsel bestaat uit rijst en cassave of maniok. Aan de Marowijne worden kwak en domi graag gegeten. Aan de Boven-Surinamerivier 
heet domi: tokoe. Dit product wordt er evenwel zelden opgediend. Domi wordt meestal in vissoep gedoopt en samen met rijst verorberd. - Banaan wordt in mindere mate gebruikt dan vroeger het geval was. - Als toespijs worden vis en wild genuttigd. De Boslandcreool is verzot op pakira. Uit de oliehoudende vruchten der cocos-, maripa- en awarrapalm worden vetten gehaald. - Rijst wordt in een zwaar vijzelblok met houten stampers door twee vrouwen in snelle regelmaat gestampt. - Over een zacht brandend houtvuur wordt op een ijzeren plaat cassavekoek gebakken. Met twee vingers worden cirkelvormige figuren door het rulle meel getrokken. Een meisje helpt het vuur met een waaier aanwakkeren. - Ook worden rijst met visjes en oker, rijst met bruine bonen en gezouten vlees, alsmede suikerriet gegeten. - Peper en zout worden bij de bereiding van het eten in ruime mate gebruikt.

Sterke drank, de eigen gebrouwen dram, wordt matig gedronken. Alcoholisme is eerder een euvel bij de Indiaan dan bij de Boslandcreool. Het opsnuiven van tabakssap is alom geliefd, terwijl oude vrouwen een pijpje allerminst versmaden.

Door het roeien zijn arm- en rugspieren krachtig ontwikkeld in tegenstelling tot de beenspieren. Hierdoor wekt de Boslandcreool soms een spillebenige indruk. Een dikke vrouw wordt als ideale schoonheid beschouwd. De voeding brengt evenwel mee dat vetlijvigheid weinig vóórkomt. Lepra wordt door de Boslandcreool gehouden voor een ziekte welke door treefoverschrijding (dus door het gebruik van een voor de betrokkene schadelijke spijs) is ontstaan.

GeijSKes (1954 a) geeft een uitvoerige beschrijving van de landbouw bij de Paramaccaners en Aucaners aan de Marowiine en Tapanahoni.

Een voornaam onderdeel van de voedselvoorziening vormt de landbouw. Daarnaast voorzien enkele bosproducten in de behoefte wat betreft spijsvetten, terwijl jacht en visvangst de dierlijke eiwitten moeten opbrengen. Gedurende honderden jaren heeft de Boslandcreool in de verre binnenlanden op dezelfde wijze gewerkt, onafhankelijk van het leven in het geciviliseerde kustgebied en vrijwel geheel buiten de belangensfeer van het Gouvernement.

Voor het planten van landbouwgewassen legt de Boslandcreool voor ieder van zijn vrouwen zogenaamde kostgrondjes aan, dat zijn opengekapte stukken land in het oerwoud waarop de gewassen worden geteeld. De kostgrondjes liggen langs de rivieren op hogere vlakke terreinen of op hellingen van heuvels. Ze zijn min of meer cirkelvormig en hebben een oppervlakte van een halve tot anderhalve hectare. - De man velt de bomen en verbrandt het gevelde bos, daarbij geholpen door familieleden en vrienden tegen verstrekking van mondkost. - De grond wordt niet bewerkt. De vrouw plant er allerlei gewassen tegelijkertijd op. - Voor ieder van de vrouwen worden twee grondjes per jaar opengekapt. De man en vrouw maken ieder afzonderlijk aanspraak op de opbrengst van één grondje. De grondjes worden in groter familieverband aangelegd en niet in gezinsverband. Iedere familie heeft een bepaald gebied waar zij het recht heeft de grondjes aan te leggen. Het grondje van de vrouw wordt in het areaal van haar familie gekapt en dat van de man in zijn familiecomplex. Eveneens heeft elk dorp zijn areaal waarbinnen de families uit dat dorp de grondjes aanleggen. De Boslandcreool is dus gebonden aan het gewoonte- 
recht van het familiebezit. - Elk jaar moeten nieuwe grondjes worden aangelegd. Aangezien er zowel een- als meerjarige gewassen worden geteeld zijn er voor een gezin steeds verscheidene grondjes in gebruik. Na drie jaren wordt het grondje weer prijsgegeven aan het opschietende secundaire bos. Deze roofbouw vordert veel land. - Door het agrarisch gewoonterecht, de uitputting van de grond en de mierenplaag is het meestal niet mogelijk langer dan twee tot drie jaar achtereen verlengstukken aan de bestaande grondjes te kappen. De kostgrondjes liggen dan ook uren en soms dagen varen van de dorpen.

Op de kostgronden wordt onder andere bittere cassave geteeld, waarvan cassavebrood, kwak en afringi worden gemaakt. Er zijn twee variëteiten van de bittere cassave: gele en witte, beide met subvariëteiten. Kwak bestaat uit droge gele korrels. De cassave wordt hiertoe in water gelegd, geraspt, verzuurd, uitgeperst en tenslotte onder omroeren gebakken. Kwak is langer houdbaar dan cassavebrood. Het wordt met water opgeweekt en met wat suiker, indien aanwezig, gegeten. Ten einde afringi te bereiden wordt vers geschilde cassave geraspt, geperst, gedroogd op het vuur of in de zon, gestampt, met water gekneed tot balletjes en tezamen met vis of vlees tot een soep gekookt. - Zoete cassave, waarvan de knollen gekookt worden, wordt weinig geplant.

Rijst is na cassave het hoofdvoedsel. Alleen 'drooglandrijst' wordt verbouwd in talrijke variëteiten. Met vlees of vis gekookt, wordt de ongeslepen zilvervliesrijst gegeten, dat wil zeggen, bij een goede oogst. Dikwijls is de hoeveelheid slechts voor enkele maanden toereikend. Dan wordt geslepen rijst uit de winkels langs de Marowijne gekocht.

Banaan wordt steeds geplant, maar toch in mindere mate dan cassave. Er zijn diverse variëteiten in gebruik. Dit product wordt genuttigd als gekookte groene banaan, als gestampte gekookte rijpe banaan (tomtom) of als 'koekoe', dat is gestampte rauwe rijpe banaan, gemengd met cassavemeel en dan gebakken. - Bacove, in verschillende variëteiten, wordt alleen vers gegeten en is zeer gewild.

Tayer wordt op alle grondjes in groepjes verspreid aangetroffen. De knol wordt met vis of vlees en olie tot een soep gekookt. Men kent hiervan een viertal variëteiten. - Bataat wordt hier en daar met slechts enkele planten bij elkaar gepoot. Er zijn drie soorten: witte, rode en gele. De knollen worden als aardappel gekookt, meestal met olie toebereid of in kleine stukken gesneden tot soep verwerkt. - Nappie ontbreekt op geen enkel grondje. Van de rode en witte soorten zijn verschillende variëteiten bekend. Nappie wordt gekookt gegeten, meestal slechts geschild, wanneer de knol tezamen met vlees wordt bereid. - Yams komt algemeen voor en wordt verspreid aangeplant. De twee soorten worden gekookt na in brokken te zijn gehakt.

Maïs wordt in de volgende vormen genuttigd: gekookte of geroosterde jonge maïs, pap van gestampte maïs, alsook asogri, dat is fijngestampte geroosterde droge korrels met suiker.

Watermeloen, in twee variëteiten, wordt overal pleksgewijs op de grondjes aangeplant en vers gegeten. - Pompoen, voorkomend op vele plaatsen, maar nooit talrijk, wordt in stukken gesneden en gekookt.

Oker, algemeen geteeld, wordt in drie soorten onderscheiden. De jonge groene vruchten worden in stukken gesneden en tot een soep gekookt, meestal tezamen met tayer, vlees enz. - Pinda en djoekapinda (agobo) 
worden plaatselijk op de grondjes en niet zelden ook in de dorpen aangeplant. De hoeveelheden die worden geoogst zijn gering. De pinda wordt gebruikt in soep of als pindakaas (geroosterd en dan gestampt). Agobo is waarschijnlijk uit Afrika geïmporteerd. - Bongila, verwant aan sesam en vermoedelijk uit Afrika afkomstig, wordt vrij veel tussen andere planten gezaaid. De rijpe zaadjes worden gedroogd in een pan op het vuur, fijngestampt en vermengd met zout. Dit product wordt als pindakaas op cassavebrood gebruikt. Soms worden de zaadjes met cassavemeel samengebakken. - Kouseband wordt weinig gebruikt.

Suikerriet ontbreekt echter nergens op de grondjes en wordt ook in twee soorten in de dorpen geplant. Men kauwt het of makkt er een stroop van, of laat het sap gisten tot een alcoholische drank (djojo). - Ananas wordt geregeld geplant. De twee soorten worden vers gegeten. - Papaja groeit langs de randen van de dorpen. De twee soorten worden vers gegeten en soms ook groen gekookt.

Cocos komt vrijwel overal in de oudere dorpen voor, maar staat gewoonlijk schraal. Het sap wordt gedronken en het vruchtvlees vers gegeten. - Koemboe, een palmsoort, wordt met enkele exemplaren in en langs de dorpen en in het bos aangetroffen. De pitten worden met warm water geweekt en gestampt tot koemboedrank. - Maripa, eveneens een palmsoort, ontbreekt in geen enkel dorp. Het witte, vettige vruchtvlees wordt vers gegeten. Uit de kernen van de pit wordt spijsolie bereid. Awarra staat in groepjes in elk dorp. De oranje vrucht wordt vers gegeten. Vaker nog wordt het tot moes gestampte vruchtvlees met suiker of suikerstroop geconsumeerd. - Pina groeit in groepen bijeen op zwampige plaatsen en wordt tot koemboe-drank verwerkt.

Manja groeit op alle dorpen en wordt vooral door de jeugd gaarne gegeten. - Lemmetje, zure oranje, sinaasappel en citroen komen verspreid voor. De eerste twee worden veelal gebruikt om er vlees en huishoudartikelen mee te wassen. - Gujave staat verspreid en wordt vooral door de jeugd geconsumeerd. - Zuurzak, hier en daar vóórkomend, wordt vers gegeten. - Kastanjebroodboom is in vele dorpen te vinden. De pit wordt geroosterd of gekookt genuttigd. - Kasjoe komt hier en daar voor en levert gewoonlijk niet veel vruchten. De vruchten worden vers gegeten, terwijl de pit soms geroosterd wordt als pinda. - Mapa wordt vers gegeten. In mei wordt deze gele peervormige vrucht door de vrouw in het bos verzameld. - Peper groeit bij de huizen of langs de rand van het dorp. De vrucht wordt in vleessoep verwerkt. - Koffie wordt hier en daar in het bos bij de dorpen gevonden.

GeIJSKES (r954 b) levert een belangrijke bijdrage over het dierlijk voedsel van de Boslandcreool aan de Marowijne.

Over het algemeen eet de Boslandcreool te veel zetmeel en te weinig eiwit. Vooral het gebruik van dierlijke eiwitten laat veel te wensen over. Gebrek aan vitaminen komt algemeen voor. - De gehele voedselvoorziening bij deze in halfwilde staat levende mens is précair. Alleen van de opbrengst van de kostgrondjes is hij verzekerd, alhoewel soms wilde dieren zich te goed doen aan zijn producten. De kostgrondjes leveren in hoofdzaak zetmeelhoudende producten op, terwijl eiwitrijke bonen en pinda alsook vitaminenrijke vruchten veel te weinig in het dagelijks menu voorkomen. 
De behoefte aan dierlijk eiwit moet worden gedekt door de opbrengst van visvangst en jacht. De weinig ontwikkelde pluimveeteelt speelt een nog veel te geringe rol. - De schaarste aan vis en wild is evenwel een opvallend verschijnsel. Er is een ernstige inbreuk gemaakt op de natuurlijke voorraden door de sedert honderden jaren ongelimiteerde jacht en visvangst, onder andere met visvergif. Wanneer na daling van het natuurlijk evenwicht de fauna niet voldoende met rust wordt gelaten, blijft dit lage niveau lange tijd bestaan. Ook de natuurlijke rijkdom aan wild en vis in de Surinaamse binnenlanden is dus aantastbaar. Een verbetering door reglementering wordt belemmerd wegens de beperkte mogelijkheid van contrôle en het ontbreken van inzicht in deze materie bij de Boslandcreool zelf.

$\mathrm{Bij}$ de visvangst wordt gebruik gemaakt van: visvallen met lokaas en valdeurtje, pijl en boog, visvergiften (zoals nekoe, boembie en koenami), hengel, kapmes (vooral in de avond bij lantaarnlicht) en afdamming van rivier of kreek.

De jacht vindt plaats met geweren. Doorgaans worden enkelloops hagelgeweren kaliber 16 gebruikt. Daarbij wordt de Boslandcreool geholpen door de afgerichte jachthonden afkomstig van Bovenlandse Indianen. Ook wordt er nog 's nachts gebruik gemaakt van een 'setigon', een op een looppad van wild gericht en tussen stokken opgesteld geweer, waarbij een bostouw aan de trekker vastgemaakt over het pad is gespannen. Niet zelden bootst de Boslandcreool geluiden na om het wild te lokken. De dieren trekken soms rond in kudden, solitair of in kleiner familieverband. Ze leven in bomen of op struiken, op of in de grond, dan wel in het water. Niet alles wat eetbaar is, wordt geschoten, want het schot moet zichzelf betalen.

De verschillende soorten dieren welke tot voeding dienen zijn: een 50-tal vissen, 2 krabben, I garnaal, 27 zoogdieren ( 7 apen, 2 luiaards, I buffel, 2 bosvarkens, I boomstekelvarken, 3 herten, 3 konijnen, 2 hazen, I stekelrat, 3 gordeldieren en 2 miereneters), 24 vogels, 3 schildpadden, 2 hagedissen, en 2 insecten. - De insecten welke worden genuttigd zijn draagmieren en larven van de palmsnuittor welke in olie worden gebakken.

De rivieren en boskreken in de bewoonde streken zijn wel rijk aan vissoorten, maar arm aan individuën, omdat ze 'uitgevist' zijn. De Boslandcreool beschikt dan ook niet over een grote keus van vis. Daarbij komt nog, dat hij niet zo'n bekwaam visser is als de Indiaan. In goede seizoenen gaat de Boslandcreool naar onbewoonde streken om er te vissen. Surplus wordt gebarbakot. - Gladvis is een treef (verboden spijs) voor de Boslandcreool. Ook mogen tweelingen noch hun moeder monki-monki (een kleine grijsgroene aap) gebruiken. - Ten einde het tekort aan dierlijke eiwitten aan te vullen zullen de pluimveeteelt en de invoer van melkvee en varkens moeten worden bevorderd.

In zijn getypt rapport brengt LEERDAM (I957) ons veel kennis bij omtrent de Boslandcreool.

De gevluchte Slaven vestigen zich langs de rivieren op strategisch gelegen plaatsen waar zij beschermd worden door de vallen. - De voorouders van de Paramaccaners moeten van paramaka aan de Paramaccarivier leven. - De rooftochten waarbij vrouwen, gereedschap, geweren, munitie en proviand worden meegenomen, zijn voor de plantage-eigenaars aan- 
leiding hulp van het Gouvernement in te roepen. Een langdurige oorlog is hiervan het gevolg. Alhoewel de troepen er vaak in slagen de dorpen te vernietigen, is het enige resultaat dat de ontvluchte Slaven verder het binnenland in worden gedreven. Tenslotte zijn de Blanken genoodzaakt vrede te sluiten. - De Boslandcreolen komen vrij en ontvangen voortaan jaarlijks geschenken van het Gouvernement. - Zij blijven echter geïsoleerd, waardoor de tradities worden gehandhaafd met uitsluiting van alle vooruitgang en civilisatie. Oppervlakkig contact met mijn- en houtmaatschappijen brengt nauwelijks verandering; geestelijken hebben meer contact, maar de levensgewoonten blijven vrijwel ongewijzigd.

Het leven van de Boslandcreool wordt voor $90 \%$ beheerst door angst. Op een verstandige wijze gehanteerd heeft die altijd succes. Hij vreest alles wat voor hem onbekend en mysterieus is. Het gemeenschapsleven wordt door drie elementen gedomineerd: list, compromis en vrees. - De Boslandcreolen denken collectief. Een functie wordt dus niet toegekend aan één individu, maar aan een béré. Alle functies worden langs de matrilineale weg toegewezen. De persoon die in aanmerking komt is de oudste zoon van de oudste zuster. Alles wordt beslist volgens het gewoonterecht. - Alle belangrijke gebeurtenissen worden teruggebracht tot de verhouding tussen de Granman en de geesten. Hij is de vader, leider, beschermer en rechter van zijn volk. - De Kapitein is detective, rechter en priester. Hij kan er zeker van zijn een goede maaltijd te krijgen waar hij ook komt. - De Bastiaan kondigt de beslissingen en orders van de Granman en Kapitein aan en ziet toe dat ze worden uitgevoerd. Hij is ook belast met de dorpshygiëne.

Een stam bestaat uit lo's, ook onderstammen of clans genoemd, en deze weer uit bérés.s. - Een béré of familie is samengesteld uit een moeder en haar kinderen. Kinderen in de vrouwelijke lijn zijn altijd familie van elkaar; die van de man niet, omdat een man er nooit zeker van is dat een kind van zijn vrouw ook het zijne is. - Gron-pikin (kinderen van de plaats) zijn afstammelingen van de oorspronkelijke vluchtelingen in de vrouwelijke linie. Wakaman (zwervers) zijn vreemdelingen behorende tot andere lo's, dan wel afstammelingen van laatkomers of van de eerste mannelijke vluchtelingen. $\mathrm{Zij}$ moeten de anderen toestemming vragen een stuk land in cultuur te mogen brengen.

In het binnenland waant de Boslandcreool zich heer en meester. Hij beschouwt regelmatig werk als een vernedering. Indien hij een stuk land, een geweer, hond, boog en pijl bezit, voelt hij zich als een koning. Hij behoeft geen betaalmiddel om te leven. In de stad is het anders. Hier heeft hij wel geld nodig voor zijn behuizing en voeding. Hij voelt zich daar dan ook een vreemdeling.

In mei is het dorp grotendeels verlaten. Alleen oude vrouwen, kinderen en invaliden blijven dan achter. - Wanneer een man een hut wil bouwen, wordt hem een stukje grond door het hoofd van de familie toebedeeld. Dit zal steeds dicht bij zijn moeders hut zijn, althans in het gebied van de béré. Indien de hut aan zijn vrouw zal toebehoren, zal de grond door de familie van de vrouw op het domein van haar béré worden toegewezen. Dit is de reden waarom in sommige gedeelten van het dorp de hutten zo dicht bij elkaar staan. - De grond wordt voorbereid en een kandoe (beschermingsmiddel voor het eigendom) geplaatst om te voorkomen dat er vuilnis wordt gestort en om de geesten te beletten op zulk een 
schoon stuk land te huizen. - Het verplaatsen van een dorp gebeurt slechts wanneer het afgebrand is of wanneer zich vele sterfgevallen voordoen. - De vrouw moet haar erf schoonhouden. Alleen tijdens een begrafenis is dit verboden. - In het dorp is diefstal onbekend.

De bouwstijl van de woningen is verschillend bij de diverse stammen. Bij sommige is de hut alleen maar een dak dat dadelijk op de blote grond staat. Bij andere zijn er twee zijwanden van ongeveer vier voet hoogte. $\mathrm{Er}$ is steeds een deur aan de voorzijde aangebracht, vaak als enige ingang. Soms is er nog een tweede deur aan de achterzijde. Een scheiding is facultatief. Er zijn geen ramen. Het dak en de wanden bestaan uit bladeren van pina, koemboe, paloeloe, tas of soms bambamaka. - Een woonhut is meestal 25 bij ro tot 12 voet en wordt bewoond door man, vrouw en kinderen. Oudere jongens verblijven bij oudere leden van de familie of in het huis van de vrijgezellen. In vele gevallen bouwt de man nog een hut voor de kinderen. - Een Aucaner hut dient tevens als keuken. Vele Saramaccaners hebben hiervoor een afzonderlijk gebouw. - In vele woningen van Saramaccaners maakt de vloer de indruk gemetseld te zijn. - Naast de gewone woning zijn er nog: de schatkamer, waarin waardevolle zaken worden bewaard, de privé-hut voor de man met hoge wanden en slechts één deur, een open keuken voor de vrouw en een rijstschuur op hoge palen.

Een meisje wordt met veel meer zorg omringd dan een jongen, omdat zij van belang is voor de instandhouding en groei van de béré en omdat zij wordt voorbereid voor het huwelijk. Ongehuwd is een vrouw verloren in deze primitieve samenleving. $\mathrm{Zij}$ kan geen geld verdienen, geen huis bouwen of huren, geen kostgrond aanleggen. - Een vrouw is het eigendom van de familie. Zij wordt als een minderwaardig schepsel behandeld. $\mathrm{Z}_{\mathrm{ij}}$ mag zelfstandig geen beslissingen nemen, dit doet haar oom of broer. Als zij besluiten dat zij moet trouwen of echtscheiden, heeft zij zich daarbij neer te leggen. En toch helpen zij haar niet met zelfs de eerste levensbehoeften.

Tijdens de verloving moet de man zijn bekwaamheid als jager tonen. Gevangen vis of wild moet hij aan zijn verloofde en haar moeder zenden. Als het meisje twaalf jaar oud is dient de verloofde een kostgrond voor haar aan te leggen. De bruidschat bestaat uit een keukenmes, een kop met zout, de benodigde dranken enz. - Het huwelijk is niet duurzaam onder deze mensen. Het wordt beschouwd als een vorm van vriendschap. - De man is het hoofd van het gezin en is verantwoordelijk voor het sociale welzijn van moeder en kind. Beslissingen over vrouw en kinderen worden evenwel genomen door de béré van de vrouw, en wel door haar oom en broer. De kinderen behoren tot haar béré. - Man en vrouw leiden hun eigen leven. Als regel bezit elk zijn eigen huis in het kwartier van zijn béré, welk om de beurt wordt bewoond. Het bezit van een eigen woning is een veiligheidsmaatregel in geval van scheiding. - De broer van een overledene is verplicht de weduwe te huwen.

Polygamie wordt niet alleen toegelaten, maar zelfs aangemoedigd. Niet zelden heeft een man drie tot vijf vrouwen. Dit heeft allerlei consequenties: r. Iedere vrouw moet haar eigen woning, boot, kostgrond en meubilair hebben. 2. De man kan allerlei met elkaar tegenstrijdige opdrachten van de verschillende families krijgen. 3. De betrekking tussen de vrouwen kan onaangenaam zijn door twist en jaloezie; de vrouwen 
noemen elkaar concurrent of vijand. 4. Bij elke maaltijd ontvangt de man voedsel van iedere vrouw, verwacht wordt dat hij van elke schotel eet. 5. Alhoewel de vrouw door dit systeem wordt beschermd tegen honger en prostitutie - er bestaat een vrouwenoverschot vooral onder de Saramaccaners - wordt zij vernederd. Het kan gebeuren dat wanneer zij de man het meest nodig heeft, hij bij een andere vrouw in een verafgelegen dorp is. - Polyandrie daarentegen wordt als een groot kwaad beschouwd. - Echtscheiding wordt aangevoeld als iets abnormaals. Door de betrokken families wordt alles in het werk gesteld om dit te voorkomen. Als het geval hopeloos is wordt een vergadering van de dorpsraad en de twee béré's belegd. - Tot echtscheiding wordt overgegaan bij overspel, mishandeling en verwaarlozing van vrouw en kinderen, onbeleefdheid tegenover de schoonouders en bij wederzijds goedvinden.

Het eten neemt in het familieleven een belangrijke plaats in. De voornaamste maaltijd wordt om ongeveer zeven uur des namiddags gebruikt en bestaat uit cassavebrood of rijst met soep van vis of wild, afgewisseld met afringi, d.i. cassavesoep met zout en gogomango.

Nadat de vrouwen het eten hebben bereid, wordt alles naar de woning van het oudste mannelijk lid van de familie gebracht. Alle andere mannelijke leden van deze familie komen daar bijeen. Dit heeft het karakter van een familiebijeenkomst en leerschool en dient o.m. om het contact en de harmonie te onderhouden.

Nadat het sein is gegeven op de lage banken te gaan zitten, duurt het soms nog een half uur voordat een ieder aanwezig is. Intussen wordt gepraat. Als allen er zijn wordt plaats genomen in volgorde naar de leeftijd rondom de schotels die op de vloer gereed staan. - Niemand durft te beginnen voor het oudste lid. Hij doopt zijn ijzeren lepel in het voedsel, waarna de anderen volgens leeftijd dit nadoen.

Tijdens de maaltijd worden vele belangrijke problemen besproken, zoals het werk, moeilijkheden, andere dorpen en toekomst. Eigendomsen erfelijk recht worden de jongeren onderwezen. Deze luisteren aandachtig, wachten op hun beurt, vullen dan hun lepel en brengen die langzaam naar de mond. Zolang het oudste lid zijn lepel niet neerlegt is het niemand toegestaan weg te gaan of met eten op te houden. - Als iemand zijn bekomst heeft dan is het enige wat hij kan doen, een kleinere portie nemen als het zijn beurt is. Zondigen tegen deze regel wordt gestraft met de hand die de lepel vasthoudt op de grond te wrijven tot die ontvelt. - De vrouwen, die afzonderlijk eten, volgen dezelfde regels. $\mathrm{Zij}$ en de kinderen gebruiken evenwel kalebaslepels.

De andere maaltijden worden in eigen huis gebruikt. Ontbijt en middageten worden eveneens door de vrouw bereid. Het ontbijt bestaat als regel uit cassavebrood of kwak met geroosterd vlees, vis of anders water. Het middageten wordt gekookt of is hetzelfde als het ontbijt.

De wijze waarop het eten wordt opgediend, kan een speciale betekenis hebben. De gewone manier is de schotels in een driehoek te plaatsen. Indien ze echter op een rij staan, met het water bij de deur, wil de vrouw hiermee zeggen: Eet en kom niet terug. - De vrouw zal de man niet uit jagen of vissen zenden. Want indien hem een ongeluk overkomt, zal zij er de schuld voor krijgen. Als hij sterven mocht zal de gehele béré lijden. $\mathrm{Zij}$ zal alleen maar aankondigen dat er geen voedsel is. Dit doet zij door het eten in één schaal te doen met de vis of het vlees op de bodem en de 
rijst daar boven op. - Alleen eten, zou de geesten uitnodigen mede aan te zitten, hetgeen een ramp zou kunnen veroorzaken. Indien een persoon geen metgezel heeft zal een kind gevraagd worden van de partij te zijn. $\mathrm{Bij}$ rouw is het niet geoorloofd gezelschap te hebben. Het voedsel wordt in een andere hut gebracht en een beetje ervan op de grond geplaatst voor de geest van de overledene. - Terugkerend zal de Boslandcreool met het dorp in zicht, eten in plaats van zich naar huis te spoeden. De reden daarvan is dat van alles kan zijn gebeurd, terwijl hij weg was: een familielid kan zijn overleden, of er kan een gevecht gaande zijn. - Wanneer de Boslandcreool in de balata-industrie werkt, neemt hij voedsel mee van huis en vult dit aan met de opbrengst van jacht en visvangst.

In de eerste levensweken wordt het kind door de moeder gezoogd en krijgt lauw water. - Een kind van één jaar krijgt des morgens een warm bad en dan wat warm water, of wordt volgepropt met cassavepap zonder suiker. Dit geschiedt door het kind tussen de benen te houden met het hoofd omlaag, de neus dicht te knijpen en de pap in de mond te gieten. Het gebeurt dan niet zelden dat het kind bijna stikt. Des namiddags geschiedt hetzelfde. Tussendoor krijgt het kind ook pap, terwijl het vrijwel voortdurend wordt gezoogd. - In het tweede jaar wordt het langzamerhand vrijgelaten wat voeding betreft.

Oudere kinderen moeten op het veld helpen. Des morgens vissen ze met een hengel of een fles waarvan de bodem is weggeslagen. De gevangen vissen geven zij aan hun moeder of koken die voor zichzelf. Op de dagen waarop zij niet naar het veld hoeven, gaan ze er met een korjaal op uit om de vis met pijl en boog te schieten. - Meisjes helpen met het huiswerk. De jongens vlechten manden en doen aan houtsnijwerk. - Een kind wordt niet bevolen iets te doen, maar vriendelijk verzocht. Het mag weigeren. Het kind straffen zou mishandeling betekenen van de geest van een voorvader die terug is gekomen in het kind.

De man jaagt, vist, legt de kostgrond aan, plant en bouwt de rijstschuur. De vrouw bereidt het voedsel en doet het overige huishoudelijke werk, zorgt voor het kind, vist, plant en oogst.

Voedsel wordt bereid door koken, bakken, roosteren en barbakotten. - Het keukengerei bestaat uit: pot, bijl, keukenmes, waterkruik, godo, kalebas, bord, houten dienblad, kop, alsmede ijzeren en kalebaslepel - De Saramaccaner is meester in het versieren van voorwerpen uit hout en kalebas. Dit doet hij door insnijdingen erin te maken. De Aucaner en Paramaccaner beschilderen gaarne hun gebruiksartikelen met figuren in heldere kleuren.

De hulpmiddelen bij de jacht zijn: geweer, opgesteld geweer, kruit, houwer, jachthond en val. Voorheen werd kruit op de plantages gestolen; thans wordt het gekocht. Ook een jachthond wordt veel gebruikt. Een val bestaat uit een zwaar blok dat op het dier valt en het verplettert.

Indien een buffalo is gedood, kan de jager het grote beest niet alleen transporteren. Hij snijdt een oor af en toont dit aan zijn dorpsgenoten, hetgeen voldoende is om de nodige hulp te verkrijgen. Het lichaam van het beest wordt in stukken gesneden welke naar het dorp worden overgebracht. - Bij de Aucaner wordt het vlees onder alle dorpsgenoten verdeeld, bij de Paramaccaner onder familieleden en vrienden. De kop wordt in een grote pot of petroleumblik gekookt. De volgende avond vindt een groot buffalofeest plaats, waarbij het vlees met cassavebrood wordt ge- 
nuttigd. - In grote dorpen als Ganzee is éen buffalo niet voldoende voor allen. Het grootste deel wordt verwerkt tot een soep. Een ieder wordt dan door de Bastiaan uitgenodigd om daarvan te genieten.

Wanneer een kudde pingo's - meestal een 200-tal - de rivier overtrekt, worden vele gedood. Tijdens het grote diner dat dan in het dorp volgt, eten velen zich ziek. $Z_{i j}$ zeggen daarbij: Beter dat de buik barst, dan dat het voedsel bederft. - Bij het verbranden van het gevelde hout op de kostgrond wordt soms verstrikt wild aangetroffen.

Aangezien in de kaaiman en boa geesten huizen, mogen ze niet worden gedood. Tweelingen mogen geen bouillon gebruiken. Wanneer een vrouw zwanger is, mag de man geen buffalo of hert doden; de geest van het beest zou zich tijdens de bevalling op de vrouw wreken.

Bij de visvangst bedient de Boslandcreool zich van: pijl en boog, hengel met haak, houwer, fuik, fles waarvan de bodem is weggeslagen, fakkellicht, lokgeluid, nekoe en vrucht als aas. - Zodra een mopévrucht in het water valt, schiet de koemaroe erop af. De Boslandcreool krijgt deze vis te pakken met behulp van een hengel met een mopévrucht of door een pijl af te schieten na een zaad of ander drijvend voorwerp in het water te hebben geworpen. - Wanneer in augustus de waterstand laag is en de rotsen bedekt zijn met mos en andere waterplanten, staat de man op een plaats waar de stroom sterk is en loert op de koemaroe die tegen de stroom in zwemt. - Bij laag getij begeven man en vrouw zich met fakkels op de rotsen en hakken op de slapende vissen die zich op de zandbanken bevinden. - Een slechte gewoonte is vis te vangen door vergiftiging van het water met nekoe. Deze vlezige liaan wordt gekneusd met stampers en dan in de kreek gedeponeerd. - Ook is een fuik in gebruik waarin aas wordt geplaatst.

Het dierlijk voedsel bestaat uit: vers en gerookt wild, kip, verse en gerookte vis, schildpad, konijn, pakira, pingo, hert en buffalo.

De slaven konden bij het wegvluchten van de plantages niet veel medenemen naar het binnenland, behalve wat tuingereedschap en zaaiplanten. Landbouw was in die tijd nog primitief en werd bedreven met houwer, bijl en hak (tjap). Tot op heden vindt onder de Boslandcreolen de landbouw met dit gereedschap plaats. - Het voornaamste gewas is cassave. Dan volgt rijst. Voorts worden geteeld: nappie, yams, banaan en pinda. Deze producten worden alleen genuttigd wanneer er een tekort is aan cassave en rijst. Ook wordt watermeloen geplant.

$\mathrm{Er}$ is onbeperkt veel grond in het binnenland, maar niet overal kan de Boslandcreool terecht.

I. Er bestaat eigendomsrecht. Wie het eerst op een stuk land de voet gezet heeft, of een kreek heeft bevaren, is de eigenaar ervan. De grond wordt onder de béré's van eenzelfde lo verdeeld.

2. Aangezien cassave het belangrijkste gewas is en geen natte grond kan hebben, moet een hooggelegen stuk land worden gekozen.

3. Op sommige plaatsen waar goden en geesten zouden huizen, mag niet worden geplant.

4. Indien de plaatselijke god van de grond het niet goedkeurt, mag er geen kostgrond worden aangelegd.

5. Er mag geen kankantrie in de buurt zijn, want een letsel aan deze heilige boom of zijn lange, boven de grond uitstekende wortels zou een ramp voor de familie teweegbrengen. 
6. Een kantamasoe (dit is een termietennest waarin een gistingsproces plaats heeft en dat bewoond zou zijn door een van de meest gevreesde geesten) wordt meestal pas ontdekt nadat het struikgewas is weggekapt; de plaats wordt dan verlaten met groot verlies aan tijd en energie.

7. De parasolmier kan de gewassen in één nacht geheel vernietigen.

8 . Een veld moet steeds dicht bij een kreek zijn voor de watervoorziening.

9. Er moet ook rekening worden gehouden met het kwade oog en de kwade mond.

Io. Rampzalig zou het zijn wanneer na het verbranden het lijk van een god, een tapijtslang zou worden ontdekt; ook dan wordt het nieuwe veld ongebruikt achtergelaten.

Om deze redenen zijn de velden zeer verspreid en ver. Er wordt veel tijd en energie verspild aan reizen naar en van de velden. De geïsoleerde ligging maakt het gemakkelijk voor wilde dieren, b.v. de pingo, zich te goed te doen aan de gewassen.

De periode van de aanleg van een kostgrond is tussen augustus en oktober. De toekomstige eigenaar van het veld gaat naar de plaats toe en bakent de grond af. De volgende dag nodigt hij een tiental anderen uit hem te helpen. Nadat het kreupelhout van het eerste veld is weggekapt, volgt nummer twee enz. Voordat daarop de grote bomen in dezelfde volgorde worden geveld, wordt de hulp van de geesten ingeroepen en wordt gejaagd, want tijdens het zware werk zijn goede maaltijden vereist. De vrouwen bereiden het voedsel. - Drie tot vier weken hierna wordt het droge hout, nadat de geesten om hulp is gevraagd, verbrand (waarbij soms grote bosbranden ontstaan). De volgende dag wordt het veld geinspecteerd om na te gaan of alles wel is verbrand en of er wild is gestrikt.

Elk jaar maakt de Boslandcreool een nieuw stuk land schoon, beplant het en laat de natuur er verder voor zorgen. Het veld wordt nooit gewied. Soms worden de gewassen overwoekerd door onkruid. - De velden tegen de berghelling worden in oktober verbrand en tot maart zo gelaten. - Als regel wordt een klein reserve-veld klaargemaakt dat in november en december wordt beplant, met de bedoeling een tekort in het voorjaar met wat rijst te kunnen overlappen.

Aangezien de humus op de berghellingen wordt weggespoeld, is het onmogelijk hetzelfde veld voortdurend te gebruiken. - Irrigatie wordt niet toegepast, men gelooft dat het delven van trenzen aanleiding zou geven tot sterfgevallen in de familie. Mest wordt niet gebruikt. Wel wordt een offer gebracht aan de 'moeder van de grond' om veel te produceren. Ook zijn er planten bekend die de grond vruchtbaar maken.

Cassave wordt geoogst in het begin van het jaar of in juni. - In maart wordt schoongemaakt en geplant. Op de plantdag komen vele mannen, vrouwen en kinderen opdagen. De padi wordt gezaaid, waarna de grond oppervlakkig wordt omgespit. De volgende dag worden cassave en andere aardvruchten geplant. - Aan de rechteroever van de Surinamerivier is het verboden op gransaba, dat is op donderdag, hard te werken. Voor de linkeroever geldt dit voor de pikiensaba of woensdag. - Oogsten is het werk van de vrouw. Terwijl de rijst rijpt, bouwt de man een schuur op of bij het veld. - Het maaien van de rijst van augustus tot oktober geschiedt coöperatief door vier of vijf vrouwen. Dit wordt met behulp van 
een mes gedaan. Het product wordt in een mand vervoerd. Voor de kleine oogst in maart en april zorgt de eigenares alleen.

Als het werk op het veld is verricht, wordt de rijst overgebracht naar de eigenlijke schuur bij de rivier. Deze hut is op palen gebouwd die voorzien zijn van een stuk blik tegen de ratten. - Bij de Saramaccaners wordt de oogst gelijkelijk verdeeld tussen man en vrouw die hun aandeel apart opbergen. Als regel hebben zij elk een afzonderlijke kostgrond. - Na de oogst vindt een feest plaats waarbij voedsel wordt geofferd aan de god.

Van het plantaardig voedsel worden nog genoemd: cassavebrood, cassavepap, kwak, gogomango, suikerriet, pindasaus, alsmede olie uit maripa en boegroemaka. Het cassavesap bevat cyaanzuur. - Als drank worden water en dram gebruikt.

De Hoog (1958) ziet in de cultuur van de Boslandcreool een duidelijke verwantschap met de Afrikaanse, doch hiernaast heeft de Boslandcreool in sterke mate de invloed van de Indiaanse en de Europese levenswijze ondergaan.

De voeding is ongeveer gelijk aan die van de Indiaan, met dien verstande dat vogels welke voor de Indiaan taboe zijn, door de Boslandcreool wel worden gegeten, terwijl hij andere beesten, zoals het gordeldier, niet nuttigt.

De Boslandcreool is een uitstekend jager en visser. Zijn jachtattributen zijn gelijk aan die van de Indiaan en grotendeels van deze overgenomen, zoals pijl en boog. Slechts de harpoenen met hun van weerhaken voorziene punten welke door middel van een koord aan de schacht zijn verbonden, wijzen op herkomst uit Afrika. - De landarbeid wordt door man en vrouw gezamenlijk gedaan, waarbij de man het zware werk op zich neemt.

Houten gebruiksvoorwerpen zoals spatels, stampers, borden en schalen, zijn versierd met snijwerk. De roerspatels vertonen de grondvorm van een peddel en zijn evenals deze sterk onderhevig aan Indiaanse invloeden. - Kalebassen worden verwerkt tot drinknap, waterkan, lepel, schep enz. $\mathrm{Bij}$ de door de man vervaardigde kalebassen zijn de decoraties aan de buitenzijde aangebracht; bij de bij de vrouw in gebruik zijnde, aan de binnenkant. - In tegenstelling tot het aardewerk van de Indiaan is dat van de Boslandcreool zeer primitief van opbouw en versiering.

VAN DER KUyP (I958) zet uiteen dat de voeding van de primitieve mens in Afrika over het algemeen niet slecht is, omdat hem een grote verscheidenheid van levensmiddelen ter beschikking staat, verkregen van primitieve tuinbouw, bosflora, jacht en visserij. Maar nauwelijks is hij het eigendom van een plantagehouder in Suriname geworden, en is hij in contact gekomen met de civilisatie, of het loopt mis met zijn voedingstoestand. De Slaaf wordt over het algemeen met plantaardige, koolhydraatrijke voedingsmiddelen (brandstof) volgestopt. Dierlijk voedsel, vet, fruit en groente worden hem onthouden of in geringe hoeveelheden verschaft. - Worden de in Nederland geldende normen voor een man die zware lichamelijke arbeid verricht als standaard aangenomen, dan heeft de volwassen mannelijke Slaaf vóór I 85 I gemiddeld gehad aan: calorieën $42 \%$, koolhydraten $63 \%$, dierlijk eiwit $27 \%$, plantaardig eiwit $32 \%$, vet $7 \%$, calcium I $3 \%$, fosfor $46 \%$, ijzer $80 \%$, vitamine A $34 \%$, vitamine $\mathrm{B}_{1} 45 \%$, riboflavine $4 \mathrm{I} \%$, niacine $63 \%$ en vitamine $\mathrm{C}_{340} \%$. (Hij $\mathrm{kreeg}$ 
VOEDINGSGEWOONTEN VAN DE BOSLANDCREOOL 25 I

toevallig heel veel vitamine $C$, onder meer afkomstig van de groene banaan.) - De eenzijdige voeding is dus geen erfenis van Afrika. - Tot heden ten dage wreken zich de op de plantages ontstane en ingewortelde verkeerde voedingsgewoonten bij de nakomeling van de naar het binnenland gevluchte Slaaf.

De Boslandcreool oefent niet gaarne de land- en tuinbouw uit. Dit is begrijpelijk. Op de plantages zijn immers zijn voorouders menigmaal op een mensonterende wijze mishandeld geworden. De landbouw wekt dus onaangename associaties bij hem op. - Het feit dat er in het gedeelte van Afrika waar hij vandaan komt weinig of niet aan veeteelt wordt gedaan, is één van de redenen waarom de Boslandcreool geen vee fokt en ook geen melk gebruikt.

Zijn zeer eenzijdige voeding bestaat hoofdzakelijk uit cassave, die weliswaar veel zetmeel bevat $(34 \%)$, maar weinig eiwit $(0.9 \%)$, alsook zeer weinig vet $(0.3 \%)$ en slechts geringe hoeveelheden van sommige mineralen en vitaminen. Om toch de benodigde hoeveelheid eiwit naar binnen te krijgen, wordt instinctmatig een stapel cassave genuttigd, zo hoog als de 'toren van Babel'. Dit is dus geen kwestie van gulzigheid, maar een behoefte.

Voor de verwerking van zo'n massa zetmeel is weer een grotere hoeveelheid vitamine $B_{1}$ en niacine nodig. Aangezien de toevoer hiervan klein is en de behoefte groot, lijden de meeste volwassen Boslandcreolen aan vitamine B-complex deficiëntie. De leek betitelt deze aandoening met goutoemanmoffo of gouddelversmond. - Voorts hebben, onder meer door het overmatig gebruik van koolhydraat, zo goed als alle kinderen een dikke buik (koolhydraat- of cassavebuik).

Het personeel van het Bureau voor Openbare Gezondheidszorg en de Landbouwvoorlichtingsdienst tracht de Boslandcreool bij te brengen groente, vruchten, melk, vlees en vis te gebruiken. Er wordt 'dried skim milk' van het Kinderfonds der Verenigde Naties, daar waar het hygiënisch verantwoord is, onder de Boslandcreoolse kinderen gedistribueerd. Doch het is geen gemakkelijke zaak tegen de traditie die indertijd op de plantages gegroeid is, te kampen.

Lichtveld (1958) komt tot de conclusie dat de Boslandcreool in zijn isolement Westafrikaanse cultuurresten heeft bewaard, maar dat hij nu meer en meer in contact komt met de bruikbare dingen uit het leven van de westerse mens. - Hij pleegt roofbouw in het binnenland. $\mathrm{Na}$ een paar jaar lang de akkers, die vaak ver van zijn dorp verwijderd liggen, te hebben uitgeput, kan hij eenvoudig een eindje verder een nieuwe kostgrond aanleggen. - Er wordt een strikte arbeidsverdeling op na gehouden. Planten, wieden, oogsten, koken, schoonhouden van huis en dorp doet de vrouw. Jagen, vissen, boten maken, vellen van bomen, en maken van de hut, is mannenwerk.

Poindexter ( $195^{8}$ ) beschouwt de Boslandcreolen als de genetisch zuiverste en sociaal-cultureel minst veranderde overplanting van Afrikanen op het Westelijk Halfrond. - Een stam bestaat uit lo's of clans, deze uit béré's of families (van matrilineale zijde) en deze op hun beurt uit hoso's of individuele families (man, vrouw en kinderen).

Tussen de huizen zijn er straten noch rechte paden. - De woning be- 
staat in het algemeen uit een enkele kamer zonder, of op zijn hoogst met één enkel venster. Een gordijn of tussenschot scheidt soms een voorkamer af. De muren en deuren zijn van hout. Het rieten dak heeft sparren van hout of bamboe. De vloer bestaat uit aangestampte klei. - In vele woningen wordt het eten gekookt in dezelfde kamer als waar men woont en slaapt. Wel wordt in de laatste tijd een begin gemaakt met buiten te koken. - De Boslandcreolen hebben veel van hun Westafrikaans karakter behouden, ook wat de voeding betreft.

De onmiddellijke omgeving van de huizen wordt goed schoongehouden, maar de onhygiënische toestanden om de dorpen waar ontlasting op de grond wordt gedeponeerd, bevordert de verbreiding van ancylostomiasis en dergelijke. De Boslandcreolen baden, wassen kleren en keukengerei, maken vis, gevogelte en groente schoon op dezelfde plaats in de rivier, die dus schromelijk verontreinigd moet zijn.

Een man kan zoveel vrouwen tot zich nemen als hij kan onderhouden. Toch is polygamie snel aan het afnemen. Iedere vrouw bezit haar eigen woning, vaak in een ander dorp. - Bij de verloving moet de jongeman zijn bekwaamheid tonen in onder meer jagen, vissen en bomen vellen. - De man is verantwoordelijk voor het sociale welzijn van het gezin, maar de vrouw domineert in de woning.

Wettige gronden voor echtscheiding zijn: I. Overspel, waaronder niet wordt gerekend de omgang met een vrouw die een andere man niet toebehoort. 2. Verwaarlozing van vrouw en kinderen. 3. Onbeleefdheid tegenover de schoonouders en -broers. 4. Impotentie. - In de laatste jaren wordt, bij sommige stammen, bij het huwelijk op ceremoniële wijze bepaald, dat degene die eenzijdig het huwelijk verbreekt zonder reden, goedgekeurd door de ouders of de vergadering, in zijn verder leven door het ongeluk achtervolgd zal worden. Hetzelfde geldt voor de man die een andere vrouw neemt zonder toestemming van zijn eerste echtgenote. En deze geeft daartoe niet gauw vergunning. De volgende vrouwen worden kambosa's genoemd, dat wil zeggen ruziemaaksters. Om al deze redenen komen echtscheiding en polygamie niet meer zo veelvuldig voor. - Meisjes behoren tot het familiebezit; zij zijn belangrijk voor het huwelijk en de bruidschat. - Tijdens de menstruatie trekt de vrouw zich in een speciale hut terug.

Een kind wordt niet mishandeld aangezien de geest van een voorzaat in hem zou zetelen. - Zodra het in staat is een paar pond te dragen, wordt het naar het veld meegenomen om de moeder bij het planten en oogsten bij te staan. - Wanneer het groter is, wordt het geleerd te vissen met haak, lijn of hand en te jagen met pijl en boog. De jongen wordt opgeleid vogels, hagedissen en kleine dieren in strikken en netten te vangen, en de hond op de jacht te leiden. Het meisje leert onder meer koken en de huishouding doen.

Het keukengerei is zeer eenvoudig. Op de meeste plaatsen wordt een ijzeren pot aangetroffen, door de man aangeschaft in een winkel in de stad wanneer hij daarheen gaat om hout te verkopen. Vele componenten van het menu worden in dezelfde pot gekookt. Dan zijn er nog een cassavezeef en -pers, alsook een mand voor landbouwproducten of vis. - In vele woningen zijn ook aanwezig een jachtgeweer, een bijl voor het vellen van de bomen en een houwer. - Bij de visvangst bezigt de Boslandcreool pijl, fuik, haak, lijn, houwer, gekneusde nekoe of de hand om de modder af te tasten. 
De vrouw etst de binnenzijde van de kalebas; de man de buitenkant. - Bij praktisch elk werk, zoals ontbossing van de kostgrond, jacht, visvangst, en bouw van een huis, is er een bepaalde ceremonie voorgeschreven. - De kostgronden worden groepsgewijs buiten het dorp aangelegd. Door de man wordt het land ontbost en worden gras en kreupelhout verbrand. De vrouw plant, past op het veld en oogst. Geteeld worden: cassave, rijst, yams, maïs en oker.

Er wordt landconservering, kunstmatige bemesting noch oogstwisseling toegepast, zodat de grond spoedig uitgeput raakt. Dan wordt een ander veld ontbost. En zo komen de kostgronden steeds verder van het dorp af te liggen, soms uren ver. In zulk een geval gaat de vrouw met haar kinderen tijdens het plant- en oogstseizoen op de kostgrond wonen. - De oogst wordt in het bovenste deel van het huis op een stellage opgestapeld of, als het koren of gedroogde bonen betreft, aan de daksparren opgehangen.

De koema-koema-mier of termiet kan de gewassen ernstige schade toebrengen. Alleen de cassave is ertegen bestand. De dorpelingen moeten daarom dag en nacht klaarstaan de mier te lijf te kunnen gaan. Ook zit de vrouw zonodig aan een touwtje te trekken dat verbonden is an een beweegbaar voorwerp om de vogels van de rijstvelden te verjagen.

Het menu bestaat hoofdzakelijk uit cassave, maĩs, yams, bataat en bonen. Hieraan worden toegevoegd: peper, zout en, wanneer beschikbaar, vis, wild of ei. Bij de meer welvarende families worden nog de volgende voedingsmiddelen opgemerkt: palmolie als vet, een verscheidenheid van gerookt vlees en vis als voornaamste eiwitbron, en ook citrus, rijst, gujave, banaan en watermeloen als bron van koolhydraat en vitamine. Drinkwater wordt uit de rivier verkregen. - Om tabak wordt gebedeld. - Bij het oproepen van geesten met de trom worden de toeschouwers en de danser door middel van alcoholische dranken voorbereid. - De gast wordt op cocossap, ei, suikerriet en gember onthaald, terwijl hij van zijn kant tabak schenkt.

Vanwege zijn hypoproteïnose en avitaminose is de Boslandcreool ontvankelijker voor pyogene infecties. - Op reis eet hij driemaal per dag cassave, geweekt in rivierwater. Vis wordt slechts genuttigd indien beschikbaar; groenten noch vruchten worden gebruikt. Wil hij dan al in staat zijn zwaar werk te verrichten, dan moet het lichaam zich biologisch aangepast hebben aan een verschillende verhouding koolhydraat-eiwit. Zijn eiwitten worden zoveel mogelijk ontzien of gesubstitueerd.

Het geloof aan taboe's en het bijgeloof bemoeilijken de normale voeding van zuigelingen en andere kinderen, de aanleg van kostgronden en de verbetering van de landbouw. - De Boslandcreool heeft diverse taboe's: I. Hij mag niet op de grond zitten; daarom gebruikt hij een bankje wanneer hij eet. 2. Hij mag geen kaaiman, slang, tijger of buizerd kwaad doen. 3. Het voedseltaboe of treef is ongelimiteerd en wisselt al naar de stam, de familie of het individu. Sommige zijn traditioneel door overerving van de vader. Andere worden verkregen door een droom. Sommigen eten geen gladvis, omdat de Bijbel dit verbiedt. De vroegere Joodse meester hield de geschubde vis voor zichzelf en gaf de Slaaf de gladvis. Aangezien groente voor de Boslandcreool gelijkstaat aan gras en onkruid en het rund deze opvreet, zijn vele groene groentesoorten eveneens taboe voor hem.

JozEFzooN (1959) maakt melding van het volgende over zijn eigen volk, de 
Saramaccaners. - Deze stam bevindt zich aan de Boven-Suriname. Alhoewel de Saramaccaner de oorspronkelijke Afrikaanse cultuur heeft weten te bewaren, is de invloed van de kustvlakte door het groeiende contact ook duidelijk te onderkennen.

Een stam vormt niet alleen een politieke, maar ook een culturele eenheid en bestaat uit lo's. Bij de Saramaccaners zijn er nu nog I2 lo's. Een lo is onderverdeeld in een aantal béré's, die op hun beurt weer zijn samengesteld uit kernfamilies (man, vrouw en kinderen). - De Saramaccaner huldigt het matrilineale stelsel. Echter geldt bij treef of spijsverbod het patrilineale principe: het verbod een bepaald soort voedsel te nuttigen erft iemand van zijn vader.

Iedere lo beschikt over verscheidene complexen gronden langs de rivier. De leden hebben daarop gebruiksrechten. Omtrent het openkappen van het bos geeft het dorpshoofd (kapitein) aanwijzingen. - In de droge tijd (september en oktober) wordt de kostgrond voor het komende jaar aangelegd door een stuk bos open te kappen, te laten drogen en af te branden. Is een jongeman ongehuwd, dan helpt hij daarbij zijn vader. - Na opruiming worden de eerste producten geplant: meloen, oker, tayerblad enz. In maart wordt het grondje schoongemaakt en wordt rijst verbouwd. - Kort daarna trekt de man weg om balata te tappen of hout te kappen. Gedurende zijn afwezigheid moet de vrouw verder voor het land zorgen. Zij oogst tegen augustus, voordat hij terug is.

De jongen houdt zich bezig met pijl en boog waarmee hij op hagedissen, vogels en visjes schiet. - Omstreeks het twaalfde levensjaar is het kind zelfstandig. Het meisje helpt nu in de huishouding. De jongen assisteert zijn vader op de jacht en visvangst. Hij wordt overal meegenomen om te wennen aan de ontberingen van het bos. - Op zeventienjarige leeftijd wordt de jongen volwassen verklaard en ontvangt van zijn vader dan meestal een nieuw geweer. - Iedere jonge man moet kunnen jagen, vissen, timmeren en de houtsnijkunst beheersen.

Het meisje leert van de moeder cassave poten, bereiden en bakken. $\mathrm{Zij}$ moet lepels en drinkschalen uit kalebas kunnen vervaardigen. Als zij niet netjes kan werken, zal ze niet gauw een goed huwelijk sluiten. Er worden wel lepels en glazen in de stad gekocht, maar deze dienen meer tot verfraaiing van het interieur dan als gebruiksvoorwerpen. - Versierd worden de cassaverasp, kalebasschaal en roerlepel. De vrouw snijdt reliëffiguren in de oppervlakte van de kalebas. Aldus maakt zij de kalebas met deksel om zout te bewaren, de drinkschaal en de lepel. Het vlechten heeft de Saramaccaner van de Indiaan geleerd. - Tijdens het bakken van cassavekoeken worden met drie vingers mooie figuren in de nog niet hard geworden oppervlakte gemaakt.

Voor de bereiding van spijsolie zorgt de vrouw. De maripapalmpitten worden tussen maart en juni geoogst. De pitten worden gedroogd, opengebroken, in een grote pan gebakken, vervolgens in een vijzel gestampt en tenslotte in grote potten ongeveer vijf uren lang gekookt. De bovendrijvende olie wordt afgeschept.

De jonge vrouw moet eten sturen voor haar verloofde. Zonder een stuk wild of een paar vissen mogen de borden niet worden teruggezonden. Midden in de week wordt hierop niet zo nauw gelet, maar op zaterdag gaan groot en klein het bos in of de rivier op om op zondag vers wild of verse vis te kunnen hebben. - Als het veel regent wordt er niet in het bos 
gejaagd, doch wel op de rivier met pijl en boog. De ervaring heeft geleerd dat de bosdieren dan liever in hun schuilplaats blijven, terwijl de vissen juist voor de dag komen, althans bij niet abnormaal hoge waterstand.

De Saramaccaners zijn over het algemeen nogal vechtlustig. Vooral overspel geeft veel reden tot ruzie.

De familieleden van een overledene moeten ervoor zorgen dat een ieder die zijn deelneming komt betuigen, gedurende acht dagen voldoende te eten krijgt. Hiertoe worden cassave, nappie en dergelijke ingezameld. Daarna wordt de weduwe of weduwnaar door de familie van de overledene drie tot vier maanden verzorgd, waarna deze zelf weer op voedsel uitgaat.

LUYKEN \& LUYKEN-KONING (1960-1962) verrichten in 1958-1959 een voedingsfysiologisch onderzoek bij verschillende rasgroeperingen in Suriname, onder meer bij de Boslandcreolen aan de Surinamerivier in de omgeving van Kabel, en aan de Cottica.

Er wordt roofbouw uitgeoefend. De kostgrondjes brengen voornamelijk cassave op waarvan platte broden worden gebakken. Verder worden andere knolgewassen verbouwd, zoals tayer (yautia), nappie, yams, bataat en tenslotte banaan, wat pinda en enkele andere gewassen. Groente wordt praktisch niet gebruikt. - De jacht en visvangst voorzien deze mensen van dierlijke producten. Het aandeel ervan in de voeding is echter niet groot. De rivieren zijn veelal leeggevist.

Een korte enquête naar de gebruikte voeding in Ganzee en Lombé toont aan dat een groot deel van de ondervraagde gezinnen uitsluitend of bijna uitsluitend cassave eet. Uit de winkels in de dorpen worden meer gebruiksartikelen dan voedingsmiddelen betrokken.

De kinderen lijden aan malaria, ancylostomiasis en ascariasis.

Serumeiwit-analyses geven de volgende uitkomsten (grammen per Ioo milliliters): totaal eiwit $7.4 \pm 0.6$, albumine $4.2 \pm 0.4$, alpha ${ }^{-}$ globuline $0.3 \pm 0.07$, alpha 2 -globuline $0.5 \pm 0.1$, beta -globuline $^{-} 0.4 \pm$ 0.11 , beta 2 -globuline $0.3 \pm 0.09$, gamma-globuline $1.7 \pm 0.4$.

De Boslandcreolen hebben een hoger totaal eiwitgehalte dan de gelijktijdig onderzochte Europeanen. Ten opzichte van de Indianen en Indonesiërs is dit evenwel lager. Het gamma-globulinegehalte is hoger, het albuminegehalte daarentegen lager dan bij de Indianen, Indonesiërs en Europeanen. Wanneer wordt aangenomen dat het albuminegehalte in de eerste plaats afhankelijk is van het eiwit in de voeding, dan volgt hieruit dat het dieet van de Boslandcreool niet voldoende eiwit bevat. Het hogere gamma-globulinegehalte is het beste te verklaren door de vele doorgemaakte infectieziekten. Het hoge totale eiwitgehalte is teweeggebracht door het hoge gamma-globulinegehalte. - Als criterium voor de eiwitvoorziening worden ook gebruikt, in een enkele portie urine bij schoolkinderen van 6-Io jaar, de verhoudingen: ureumstikstof-totaal stikstof, ureum-kreatinine en ureum-soortelijk gewicht. Op grond hiervan blijkt bij de onderzochte Boslandcreolen de eiwitvoorziening duidelijk slechter te zijn dan bij de Indianen, Indonesiërs en Europeanen.

De hoeveelheid stikstof die het lichaam werkelijk ten goede komt, kan worden bepaald uit stikstofbalansstudies. Bij 7 Boslandcreoolse kinderen worden deze proeven uitgevoerd. Zij krijgen een kost die hun eigen voeding zoveel mogelijk benadert. De totale hoeveelheid eiwit en het percentage dierlijk eiwit zijn veel lager dan de Nederlandse normen. - De gemiddelde 
stikstofopneming is 4.7 gram, waarvan $0.6 \mathrm{~g}$ uit dierlijk eiwit. In de urine wordt gemiddeld $2.7 \mathrm{~g}$ uitgescheiden en in de faeces $1.1 \mathrm{~g}(23 \%$ van wat werd opgenomen). Gemiddeld wordt $0.82 \mathrm{~g}$ geretineerd, dat is $17.5 \%$ van de opgenomen hoeveelheid. Dit percentage schijnt voldoende te zijn. Doch bij Indonesiërs en een Hindustaans kind was dit veel hoger.

Bij eiwittekort zouden de amylase-, lipase- en cholineësterase activiteit van het bloedserum sterk verminderd zijn. De amylase-activiteit van het serum van Boslandcreolen, Indianen en Indonesiërs is hoger dan die van Europeanen. De lipase- en cholineësterase-activiteit zijn bij de Boslandcreolen lager dan bij de andere rassen. - Het cholesterolgehalte van het bloedserum is bij mannelijke Boslandcreolen $\mathbf{I}_{42} \pm 31 \mathrm{mg}$ per $100 \mathrm{ml}$, bij vrouwelijke $\mathbf{r}_{55} \pm 35$, bij mannelijke + vrouwelijke Indianen ${ }_{5} \mathbf{I} \pm$ 27, bij mannelijke Indonesiërs $164 \pm 34$, bij vrouwelijke $202 \pm 39$, bij mannelijke Europeanen $221 \pm 46$ en bij vrouwelijke $220 \pm 22$. - De Boslandcreolen gebruiken zeer weinig vet. Dit is dan nog voornamelijk uit palmvruchten.

Het gemiddelde haemoglobinegehalte is $12.4 \mathrm{~g}$ per $100 \mathrm{ml}$. - Het nuchter serumijzergehalte is bij de Boslandcreolen lager dan bij de Indonesiërs en Europeanen (resp. 62, I I0 en Ir6 gamma per roo ml.) - De 2-uursstijging na orale belasting met ijzer, is bij de Boslandcreolen hoger dan bij de Indonesiërs en Europeanen (resp. r66, 65 en $83 \%$ ). De latente ijzerbindingscapaciteit is resp. 213,180 en 230 gamma per 100 $\mathrm{ml}$. De totale ijzerbindingscapaciteit bedraagt resp. 275,283 en 346 gamma per roo $\mathrm{ml}$. - Het lage nuchter serumijzergehalte kan op ijzergebrek in de voeding wijzen, maar het kan ook het gevolg zijn van parasitaire ziekten. Ook de relatief hoge 2-uursstijging kan op ijzertekort duiden. - De lage ijzerbindingscapaciteit kan worden toegeschreven aan de aanwezigheid van infecties.

Vergeleken met Amerikaanse kinderen zijn Boslandcreoolse achter in skeletleeftijd: bij de jongens op Kabel 9, in Moengo 5 en in Albina 13 maanden; bij de meisjes op Kabel II en in Albina I3 maanden. Gezien de kleine aantallen is het moeilijk waarde te hechten aan de regionale verschillen. Bovendien is de kalenderleeftijd niet nauwkeurig bekend. Bij Indianen en Indonesiërs is de achterstand nog groter. En toch is de voeding van de Boslandcreolen beslist slechter. Misschien spelen daarbij ook andere factoren een rol. - Transverse lijnen in de radiale metaphyse worden bij $27 \%$ van de jongens en $50 \%$ van de meisjes gevonden. Deze lijnen wijzen op doorgemaakte perioden van groeistilstand.

Het calciumgehalte van zog van Boslandcreoolse vrouwen bedraagt gemiddeld $22.8 \mathrm{mg}$ per roo ml, van Europese 28.0. - Bij 17 Boslandcreolen worden calciumbelastingsproeven genomen: $29.6 \%$ van het intraveneus toegediende calcium wordt in de eerstvolgende 9 uren uitgescheiden; bij Indonesiërs is dit $4 \mathrm{r} .8 \%$. Aangezien de normale waarden tussen 25 en $45 \%$ liggen, zijn de calciumvoorraden in het skelet dus normaal. - Uit calciumbalansstudies blijkt dat de gemiddelde dagelijkse opneming van calcium bij Boslandcreoolse kinderen van 4-II jaar, 207 mg bedraagt. Hiervan retineren zij $36 \mathrm{mg}$. De faeces bevat gemiddeld r29, de urine $\mathbf{4 2} \mathrm{mg}$ per dag. - Een deel van de onderzochte kinderen retineren voldoende calcium voor de groei, een ander deel echter niet. De gemiddelde retentie van de hele groep is te laag. - De absorptie door het darmkanaal $(40 \%)$ is hoger dan bij Amerikaanse kinderen (3r\%), maar lager dan bij 
Indonesiërs $(62 \%)$. De retentie $(18 \%)$ is ongeveer gelijk aan die bij Amerikaanse kinderen (19\%), maar lager dan bij Indonesische $(28 \%)$.

Somatometrische onderzoekingen worden bij 655 Boslandcreolen verricht. Ten einde daaruit conclusies over de voedingstoestand te kunnen trekken, worden de maten vergeleken met die van dezelfde raciale groepering uit de Nederlandse Antillen. De Boslandcreolen blijken veel korter te zijn dan de Antillianen. Voorbeelden: jongens van $61 / 2$ jaar resp. 108.4 en $117.7 \mathrm{~cm}, 9^{1 / 2}$ jaar 123.8 en $133.5 \mathrm{~cm}$, mannen 162.4 en $175.8 \mathrm{~cm}$, vrouwen 152.6 en $164.8 \mathrm{~cm}$. Daarentegen zijn de breedtematen (borstomvang, schouder-, borst- en bekkenbreedte), berekend per $100 \mathrm{~cm}$ lichaamslengte, groter dan die van de Antillen, met uitzondering van de bekkenbreedte bij vrouwen. De Boslandcreolen zijn dus 'breder' gebouwd.

$\mathrm{Bij}$ de zoveel kortere Boslandcreolen is het gewicht natuurlijk kleiner dan bij de Antillianen. Voorbeelden: jongens van $6^{1 / 2}$ jaar resp. I 8 . I en $20.5 \mathrm{~kg}, 9^{1 / 2}$ jaar 24.6 en $27.9 \mathrm{~kg}$, mannen 57.5 en $69.0 \mathrm{~kg}$, vrouwen 51.9 en $70.4 \mathrm{~kg}$. - De gewichtscoëfficiënt is bij de Boslandcreolen eveneens minder. Ook is het gewicht minder dan het theoretisch gemiddelde van Pryor, berekend naar de lengte, borst- en bekkenbreedte.

Het verschil in lengte en gewicht tussen de twee groeperingen kan slechts door uitwendige factoren zijn veroorzaakt. Deze kunnen direct van invloed erop zijn geweest of via selectie. Een van de meest voor de hand liggende factoren is de (vooral vroeger) slechtere voeding in het Bosland. Momenteel kan niet (meer) van een beslist slechte voedingstoestand of ondervoeding bij de onderzochte groep worden gesproken. - Uit de gegevens betreffende de jongere kinderen blijkt dat de groei in het tweede levensjaar vertraagd is. Dit zou kunnen wijzen op een onvoldoende eiwitvoorziening.

De gemiddelde ABC-index (armomtrek in procenten van de lichaamslengte) is steeds groter dan bij de Antillianen. Deze maat wordt voornamelijk bepaald door de spiermassa. Door het hanteren van pagaai en koelastok bij het varen, zijn de armspieren van de Boslandcreool goed ontwikkeld. Maar reeds bij de kinderen is deze index hoog. - De gemiddelde buikomtrek is telkens groter dan bij de Antillianen. Over het algemeen wordt die door de hoeveelheid vet beïnvloed. Doch aangezien de overige vetmaten bij de Boslandcreool in een andere richting wijzen, zou de grotere buikomvang zijn oorzaak kunnen vinden in een andere houding, in chronische worminfestaties, meteorismus (opgeblazenheid) en/of miltvergroting.

Het onderhuidse vet bij de kinderen is op alle gemeten plaatsen minder dan bij de Antillianen. Hierdoor is voor een groot deel de lagere gewichtscoëfficiënt te verklaren. - Alhoewel de vrouw en het oudere meisje meer onderhuids vet bezitten dan de overeenkomstige mannelijke Boslandcreolen, hebben zij daarvan toch minder dan de Europese en Amerikaanse. - De densiteit bij mannen van 18-25 jaar bedraagt I.ogr (bij de jonge Amerikaan 1.07o, bij de Europese Nederlander 1.088). Deze maat komt overeen met een lichaamsvetgehalte van $3.7 \%$. Elders wordt bij de gezonde jongeman $13.9 \%$ en na hongeren $5.2 \%$ gevonden. De absolute hoeveelheid vet bij de Boslandcreool is $2.1 \mathrm{~kg}$. Het vetvrij gewicht is dus $55.4 \mathrm{~kg}$ of $34 . \mathrm{rg}$ per $100 \mathrm{~cm}$. Bij de gezonde Amerikaan bedraagt dit resp. 59.7 en 38.8 , na 23 weken hongeren 50.8 en $28.5 \mathrm{~kg}$; en bij de inactieve gezonde Amerikaan van ongeveer 50 jaar $32.2 \mathrm{~kg}$ per $100 \mathrm{~cm}$. 


\section{AAN DIT CHRONOLOGISCHE LITERATUUROVERZICHT ZOU DE}

SCHRIJVER NOG HET VOLGENDE WILLEN TOEVOEGEN

De dorpen van de Boslandcreolen liggen aan de rivieroever en wel op een hoog gedeelte met zanderige klei. In r939 telt Ganzee, het grootste Boslandcreolendorp, 829 zielen en 38I woningen, dat is gemiddeld 2,2 persoon per woning. In I959 bedragen deze cijfers achtereenvolgens I2I5, 668 en I,8.

In tegenstelling tot het Indianendorp waar de woningen groepsgewijs staan en er tussen de groepen min of meer lange paden zijn, zijn de Boslandcreolenwoningen opeengepakt en zonder enige regelmaat geplaatst. Er ontbreken dan ook straten. Wel zijn de woningen van eenzelfde familie bij elkaar. De haard of stookplaats bevindt zich soms in de voorkamer van de slecht geventileerde hut, maar meestal in een afzonderlijke keuken.

De middelen van bestaan zijn: land- en tuinbouw, jacht, visvangst, kippenteelt, verzameling van bosproducten, ruilhandel, verkoop van hout, balata en houtsnijwerk, vervoer van personen en vracht, begeleiding van expedities, veldarbeid voor Gouvernement en ondernemingen, enz. Vele van deze werkzaamheden nopen de man maandenlang van huis te zijn.

De Boslandcreool huldigt het matrilineale stelsel. Zijn levenswijze berust hoofdzakelijk op traditie en religie. Bijgeloof speelt een grote rol in zijn voedingsgewoonten. Vanwege de voortdurende, harde strijd om het bestaan is deze primitieve mens egocentrisch. In Voetoe-na-Kaba aan de Boven-Suriname was de samenleving op communistische grondslag gebaseerd, maar sinds het overlijden van het betrokken dorpshoofd in 1949 is dat niet meer zo.

Polygamie is gebruikelijk. Aangezien in deze primitieve samenleving slechts het moederschap zeker is, behoren de kinderen de moeder en haar familie toe. Toch heeft bij de gedoopten de vader thans meer zeggenschap over zijn kinderen. Bij menstruatie betrekt de vrouw een hut buiten het dorp. Deze afzondering vindt niet meer plaats in de Christendorpen.

Tot de taken van de man behoren onder meer het plantklaar maken van de kostgrond, vervaardigen van houten gebruiksvoorwerpen, jagen, vissen en opleiden van de jongen. De vrouw verzorgt haar kind, bereidt het voedsel en verricht andere werkzaamheden in de huishouding, plant, oogst en houdt de kostgrond schoon, leidt het meisje op, vist en vervaardigt gebruiksvoorwerpen uit kalebas. De jongen moet de man behulpzaam 
VOEDINGSGEWOONTEN VAN DE BOSLANDCREOOL 259

zijn bij het jagen, vissen, aanleggen van de kostgrond en vervaardigen van houten gebruiksartikelen. Het meisje dient te helpen in de huishouding, op de kostgrond, bij het vissen, met de verzorging van kleine kinderen en de vervaardiging van gebruiksvoorwerpen uit kalebas.

Het keukengerei wordt aan de rivieroever zó lang met zand gepoetst tot het van binnen en buiten glimt. Zeep wordt uit de winkel betrokken. Alhoewel de Boslandcreolen zindelijk zijn, hetgeen hun voorouders van hun vroegere Israëlietische plantagemeesters hebben geleerd, kennen zij de meest elementaire hygiënische regels niet.

De wijzen waarop voedingsmiddelen en gebruiksvoorwerpen worden verkregen zijn: r. Cultivering van sommige gewassen op de kostgronden en in de dorpen. - 2. Verzameling van wilde vruchten, zaden enz. in het bos. - 3. Verzameling van wilde honing en voorheen palmwijn. - 4. Verzameling van eetbare insecten. - 5. Jacht. - 6. Visvangst. - 7. Krabben- en garnalenvangst. - 8. Kippen- en schildpaddenteelt. - 9. Aankoop van artikelen in Paramaribo, Albina, Moengo, enz., op een plantage, in een nederzetting of een dorp. - ro. Ruilhandel in Paramaribo of een andere stad, op de plantages, dan wel bij de winkelier in het dorp. - II. Dienstbetoon, waarvoor soms voedsel, drank en dergelijke worden ontvangen. - I2. Bedelarij om alcoholica, tabak, brood, beschuit, bakkeljauw en snoep. - I3. Schenkingen van gouvernementsinstanties (onder meer alcoholica, tabak en bakkeljauw), of van de toerist (boterham, snoep, sterke drank, bakkeljauw en tabak), en voorts van het Kinderfonds der Verenigde Naties (melkpoeder). - I4. Plundering van de plantages (vroeger).

- I5. Toediening van moedermelk.

In de winkels die zich in de Boslandcreolendorpen bevinden zijn onder meer verkrijgbaar: rijst, brood-en sodabeschuit, bloem (meel), gomma, suiker, koek, suikergoed, gecondenseerde melk, ingeblikt vlees zoals corned en roast beef, ingeblikte vis zoals sardines en zalm, gezouten vlees, bakkeljauw, haring, bokking, spijsolie, kaneel, nootmuskaat, kerrie, zout, thee, koffie, cacao, tabak, sigaret, orgeade, cola- en andere gazeuze dranken, wijn, bier, rum, zeep, lucifer, keukengerei en andere gebruiksartikelen.

De voeding van de Boslandcreool is eenzijdig en onvolwaardig. Het voedsel bevat een overmaat van koolhydraten, maar te weinig vet, mineralen, vitaminen (vooral van het B-complex) en eiwit (vooral dierlijk eiwit). 
Het eten wordt bereid door: koken, braden, stoven, bakken, roosteren, braden aan het spit en barbakotten. De keukentechniek is nog voor een deel afkomstig uit de plantagetijd.

Kinderen worden tot na het tweede levensjaar gezoogd. In de Christendorpen geschiedt dit tot $\mathrm{I}^{1} / 4$ jaar. Wordt het kindervoedsel ver in het binnenland nog steeds door de moeder voorgekauwd, dit geschiedt niet meer in de half-geciviliseerde dorpen. Zuigelingen en kleuters wordt gongotee- of bananenmeelpap toegediend. Het hoofd wordt hierbij achterover gehouden, de neus dichtgeknepen en een enorme hoeveelheid pap in de keel gegoten.

De gebruiksvoorwerpen die betrekking hebben op de voeding zijn van: I. Hout: vijzel, stamper, cassavetrog, dienblad, eetlepel (voorheen), suikerrietpers, roerspatel, stampertje om koemboe in een pot van het vruchtvlees te ontdoen, laag eettafeltje, korjaal om alcoholische drank te bereiden, bak en stok voor het dorsen van rijst, kist. - 2. Kalebas: waterhouder, drinkschaal, eetschaal, schep- en eetlepel. - 3. Aardewerk: waterkruik. 4. Vlechtwerk: cassavepers, vuurwaaier, mand en zeef. -5 . Metaal: ijzeren of aluminium pot, ijzeren pan, ijzeren cassavebakplaat, bord, eet- en scheplepel, vork, mes, kroes of kan, houwer, blik, cassaverasp, zeef, emmer en koffer. - 6. Glas, porselein enz.: drinkglas, bord, schaal, kop en schotel, fles. - 7. Plastic: bord, kroes, lepel, tang, emmer, zuigfles en veldfles. -8 . Ander materiaal: lucifers, zeep en steen om pitten te kraken.

Het tuingereedschap bestaat uit: bijl, houwer, kap (tjap), draagmand, kalebas voor de zaaipadi, stok om de jonge bananenplant over te poten, en soms schop en hark.

De gebruiksvoorwerpen worden zelf vervaardigd uit hout, kalebas, klei, riet enz., door Gouvernement of toerist geschonken, dan wel aangekocht. Ze dienen voor: keuken, landbouw, jacht, visvangst, vervaardiging van de benodigde voorwerpen, schoonmaak, vervoer van producten enz. Een op een plankje vastgespijkerd stuk blik waarin met een spijker gaatjes zijn geboord, dient als rasp. Overigens wordt een rasp uit de winkel gebezigd. De voorwerpen uit hout of kalebas worden door insnijdingen kunstig versierd.

De houten vijzel wordt gebruikt om rijst te ontbolsteren, banaan tot tomtom te stampen, cassaveperskoeken te verpulveren, gebakken pinda tot pindakaas te maken, peperpoeder te bereiden en palmpitten van de schil te ontdoen. Het dienblad wordt gebezigd om voedsel op te dienen, rijst te wannen, cassavebrood op te stapelen en vaatwerk naar en van de rivieroever te vervoeren. 
Bij de jacht heeft men als hulpmiddelen: pijl en boog, opgestelde pijl en boog, geweer, opgesteld geweer, val, houwer, knots (kodja), jachthond, volgen van het spoor en (voorheen) werpspies. Gejaagd wordt op grof en klein wild, gevogelte enz. In de vroege ochtend komen weleens konijnen en herten aan de bittere cassave op de kostgrond vreten; zij vormen dan een gemakkelijke prooi voor de jager.

Er wordt gevist door man, vrouw en kinderen. De hulpmiddelen hierbij zijn: pijl en boog, fuik, vishaak, pijl als spies, lijn, hengel, aas, afdamming van een riviertje of kreek, visvergif, houwer, knots om nekoe fijn te slaan en korjaal om de gekneusde nekoe uit te logen.

Bij het gebruik van visvergif zoals nekoe, worden ook de kleine vissen gedood en het biologisch evenwicht verstoord, zodat de waterplas geruime tijd geen vis meer kan opleveren.

Als aas dienen: pier, visje, kikkertje, hagedisje, vlees, kaas, cassavebrood, bittere cassave, rijpe banaan, diverse vruchten en zaden. Visjes, kikkertjes en hagedisjes worden in een fuik gedaan.

De behoefte aan dierlijk eiwit wordt gedekt door: jacht, visvangst, kippenteelt, vangst van leguanen, schildpaddenvangst en -teelt, en voorts aankoop (spek, bakkeljauw, gezouten vlees alsook ingeblikt vlees en vis). Pluimvee wordt weinig of niet gehouden. Vee wordt niet gefokt. De redenen hiervan zijn gebrek aan weiden en het feit dat in West-Afrika weinig of niet aan veeteelt wordt gedaan.

Was het binnenland vroeger rijk aan wild en vis, thans is het in de bewoonde streken hieraan arm geworden vanwege de ongelimiteerde jacht en visvangst. Er is dan ook gebrek aan dierlijk voedsel.

De Boslandcreool is dol op spek. Gecondenseerde melk uit de winkel wordt soms in cacao, thee of koffie gedaan. Ei van kip, boshen, patrijs, schildpad en leguaan wordt slechts af en toe genuttigd.

Overgebleven vlees en vis worden gebarbakot. Na inzouten wordt vis zonder bezwaar in de zon gedroogd. Adellijk vlees en vis worden niet versmaad. Soms worden vlees en vis met kerrie toebereid.

De man neemt het beste deel van het vlees en de vis voor zich. Toch zorgt de vrouw ervoor dat zij niet tekort komt. Het kind krijgt dus het minst. Door de jongeren mogen bepaalde gordeldieren alsook het stekelvarken niet worden gegeten. Onthouding. 
van jacht op en van gebruik van warmbloedig wild op zaterdag zijn overgenomen van de Israëliet. Op vele plaatsen is een andere dag hiervoor bestemd. Aan de Boven-Suriname b.v. geldt dit verbod voor sommige velden op woensdag, voor andere op donderdag, die daar resp. Pikien en Gran Saba (Kleine en Grote Sabath) worden genoemd. De Boslandcreool eet geen tijger, slang en kikker en ook niet bepaalde vogels; evenmin een dier dat door hem is grootgebracht.

Het aanleggen van de kostgrond geschiedt door vellen van bomen en struikgewas in het oerwoud, drogen van het gevelde hout, bijeenbrengen en verbranden van het materiaal. Zulk een kostgrond bevindt zich uren tot dagen varen van het dorp. Er wordt roofbouw uitgeoefend: de grond wordt niet bemest. De Boslandcreool plant juist voldoende voor zichzelf en zijn gezin. Als de oogst mislukt, is er hongersnood. De rijst op de kostgrond wordt soms aangetast door een merkwaardig insect, de (vliegende) veenmol of kotikoti.

Geconsumeerd worden: rijst, aardvruchten (bataat, cassave, dasjien, nappie, tayer en yams), banaan, maïs, pinda en suikerriet. Deze producten worden op de kostgrond geteeld. De voeding is in hoofdzaak plantaardig. Op sommige plaatsen is cassavebrood het voornaamste stapelproduct, op andere rijst waarnaast cassavebrood, op weer andere cassavebrood en in de tweede plaats rijst.

Om cassavebrood te bereiden wordt de bittere cassavewortelknol geschild, gewassen, tot een brij geraspt, in een matapi uitgeperst, boven een vuur of enige uren in de lucht dan wel in de zon gedroogd, in een vijzel fijngestampt, gezift door een gevlochten warimbozeef met wijde mazen en dan door een in de winkel gekochte zeef, op een grote ronde ijzeren plaat gebakken, in de zon gedroogd en tenslotte in een koffer, kist of iets dergelijks bewaard. Van cassavemeel worden bereid: cassavebrood, kwak, knoedel, pap, tapana (een alcoholische drank), pannekoek, bojo en ander gebak. In rivierwater gedoopt cassavebrood wordt met bakkeljauw gegeten. Aan de Coppename wordt cassavebrood dat gedurende een nacht in water heeft gestaan, gebruikt om dik te worden. Van de neerslag van het uitgeperste, giftige, bittere cassavesap, gomma genaamd, wordt gommakoek en soms pap gemaakt. Door koken van het sap verdwijnt het gif en wordt een saus, casripo, verkregen.

Banaan wordt gegeten in de vorm van: gongotee of bananen- 
meel, knoedel, tomtom, geroosterde geschilde groene banaan, geroosterde ongeschilde rijpe banaan, gekookte hele groene banaan, gekookte groene bananenschijven, gebakken schuin gesneden groene banaan of bananenchips, gebakken hele rijpe banaan, gebakken schijven rijpe banaan en ander gebak (dokoen). Dokoen is een in bananenblad gewikkeld gebak bestaande uit gestampte rauwe rijpe banaan, cassavemeel of rijst, pindakaas, geraspte cocos, spijsolie, suiker en nootmuskaat of kaneel.

Bataat wordt soms ook als een soort tomtom in soep gebruikt; hetzelfde gebeurt somtijds met nappie.

Het dorsen van padi geschiedt in een vijzel, in een houten bak, met een stok, of in een zak die op de schoot met de handen wordt bewerkt. Zelfverbouwde rijst wordt vóór deze de pot ingaat, niet uitgewassen wanneer de verse padi boven een vuur was gedroogd, anders eenmaal. Gekochte rijst ondergaat deze bewerking twee tot drie keren.

Jonge maïs wordt in water met zout gekookt.

De meelsoorten die worden gebruikt zijn: blom uit de winkel, gomma, cassave-, bananen-, maïs- en rijstmeel. Van blom wordt pannekoek gebakken en van gomma gommakoek. Uit de andere meelsoorten wordt pap bereid. Bananenmeelpap is een geliefde kindervoeding. Bojo is een gebak dat cassavemeel, cocos, suiker, kaneel, nootmuskaat en spijsolie bevat.

Groente wordt slechts af en toe geconsumeerd. In gebruik zijn: agoemawiwiri, amsoi, bitawiwiri, gogomango, klaroen, kouseband, oker, peperblad, pompoen, postelein, sopropo en tayerblad. Kabbes en de schil van watermeloen worden weinig gebruikt.

Peulvruchten worden zelden of niet gegeten. De volgende zijn in gebruik: black eye peas, botropesie, djaripesie en kouseband.

Geraspt cocosvruchtvlees wordt weleens met water verdund, uitgeperst en vervolgens tezamen met gogomango en oker gekookt tot een soep.

Spijsolie wordt verkregen uit de volgende palmpitten: amana, boegroemaka, cocos, maripa en paramaka.

De volgende vruchtbomen worden in het dorp of bos aangetroffen: ananas, awarra, bacove, casjoe, citrus (alamoen, citroen, grape fruit, lemmetje, sinaasappel, zure oranje), cocos, gujave, knippa, koemboe, manje, maripa, mopé, papaje, pommerak, sterappel en zuurzak. Pinda wordt hier en daar geplant. Vruchten, zaden en aardnoten worden zelden gebruikt. Vruchten worden niet tijdens, maar tussen de maaltijden in genuttigd. Alhoewel 
in de dorpen tussen de opeengepakte huizen wat vruchtbomen verspreid voorkomen en het bos vele vruchten en zaden biedt, is de individuele consumptie van deze producten, vooral onder de volwassenen, gering.

De Boslandcreool gebruikt allerlei soorten peper. Hiervan wordt soms peperpoeder gemaakt: de peper wordt voorzichtig in een vijzel gestampt, gezeefd, uitgewassen, in de zon gedroogd, wederom fijngestampt, met zout vermengd en nogmaals gezeefd. Andere specerijen zijn: kerrie voor het kruiden van vlees of vis, kaneel en nootmuskaat voor de bereiding van bojo en pannekoek en voorts gember voor het maken van gemberdrank.

Honing wordt van de wilde bijen of uit de winkel verkregen. Suikergoed en koekjes betrekt de Boslandcreool uit de winkels of verkrijgt die van de toerist. Chocolade ontvangt hij eveneens van de toerist. Suiker en stroop bereidt hij vaak zelf uit suikerrietsap of koopt die in de winkel, evenals melasse.

Alhoewel zout, dat bij zakkenvol in Paramaribo wordt aangeschaft, een zeer geliefkoosd component in de voeding is, geloven sommigen dat het de geest zou verzwakken en vermijden het daarom angstvallig.

De ouderen, vooral de vrouwen, roken gaarne een pijp; de jongeren geven de voorkeur aan een sigaret. Een sigaar verkregen van de toerist wordt ook opgestoken. Tabakssap wordt opgesnoven. Doorgaans geschiedt dit kort vóór het slapen gaan, bij het opstaan en na de maaltijden. Aan de Boven-Saramacca worden tabaksbladeren met water bevochtigd en verwarmd, waarna as wordt toegevoegd. Het product wordt als pruim gebruikt.

De gewone drank is ongekookt water uit rivier, moeras of boskreek. Ook regenwater, opgevangen in een emmer of brede kalebas, wordt gedronken. Op zijn tochten door het bos gebruikt de Boslandcreool in tijd van nood water uit de bladoksels van de grote paloeloe.

Er wordt vrij veel cacao gedronken alsook een drank bereid uit de koemboe- of pinapalmvrucht. Deze twee zijn cacaosurrogaten. Thee wordt hoe langer hoe meer in de half-geciviliseerde dorpen gebruikt, alhoewel sommigen menen dat dit vermagerend werkt. Uit citroengras wordt een theesurrogaat bereid. Koffie wordt zelden gezet.

Met water verdund, gesuikerd lemmetjessap dient des morgens 
VOEDINGSGEWOONTEN VAN DE BOSLANDCREOOL 265

vaak als drank. Eveneens wordt, ofschoon zelden, verdund zuur oranje-en citroensap met suiker gedronken. Af en toe drinkt de Boslandcreool suikerrietsap, verdunde honing, stroop, melasse en orgeade, alsook gemberdrank en uitgeperste zuurzak met suiker. Uit de winkel of door koken van suikerrietsap verkregen stroop wordt in cacao, koffie en thee gedaan.

Aangezien de Boslandcreool aan de Boven-Coppename gelooft dat cocossap impotentie in de hand werkt, gebruikt hij dit niet; elders wordt het echter wèl gedronken.

Cola- en andere gazeuze dranken zijn verkrijgbaar in de winkels die in de grotere dorpen worden aangetroffen. Ook alcoholica zoals dram, jenever, bier en likeur zijn voorradig. Palmwijn is niet meer in gebruik. Het misbruik van alcoholische drank stamt voor een groot deel uit de slaventijd toen de plantageeigenaar aan de uitgeputte menselijke machine dram, dus blote calorieën, toediende om er aan energie zoveel mogelijk uit te halen. 


\section{LITERATUUR}

T. Arkieman, 1945. Suriname - Het vergeten land. (p. IC2-103, 109, I79) W. L Salm \& Co., Amsterdam.

(Prins) R. Bonaparte, 1884. Les habitants de Suriname; notes receuillies à l'exposition coloniale d'Amsterdam en I883. (p. 124-125) A. Quantin, Paris.

G. B. Bosch, 1843. Reizen in West-Indië en door een gedeelte van Zuid-en Noord-Amerika. (p. I2I-122) L. E. Bosch \& Zoon, Utrecht.

J. van DEN Bosch, 18r8. Nederlandsche bezittingen in Azia, Amerika en Afrika. II. (p. I97) Gebr. Van Cleef, 's-Gravenhage/Amsterdam.

C. van Coll, 1903. Gegevens over land en volk van Suriname. Bijdragen tot de taal-, en volkenkunde van Nederlandsch Indië 7, 55, p. 530-584.

A. M. Coster, 1886. De Boschnegers in de Kolonie Suriname. Bijdr. taal land volkenk. Ned. Indië 3, I, p. I-36.

J. W. S. van EycK, 1830. Beschouwing van den tegenwoordigen staat, zeden en gewoonten van de Saramaccaner bevredigde Boschnegers in deze Kolonie. Surinaamsche Almanak, p. 260-275.

P. C. FLU, 1912. Rapport over het wetenschappelijk onderzoek naar het vóorkomen der malaria in de bovenlanden der Kolonie Suriname en de bestudeering van die ziekte. (p. 73-78) Alg. Landsdrukkerij, 's-Gravenhage.

D. C. Geijskes, 1954ª . De landbouw bij de Bosnegers van de Marowijne. W. I. Gids 35, p. 135-153.

D. C. Geijskes, $1954^{\text {b }}$. Het dierlijk voedsel van de Bosnegers aan de Marowijne. Vox Guyanae I, p. 6I-83.

B. M. Goslings, 1934. De Indianen en Boschnegers van Suriname. (p. 2426) Gids in het Volkenkundig Museum I3, Koloniaal Instituut.

P. A. DE Groot, 1953. Dokter in het oevwoud. (p. 65-73, 98, I12-II3, II6, I3I, 138-145, I8o) C. F. Callenbach, Nijkerk.

J. G. W. J. Eilerts de HaAn, I9Io. Verslag van de expeditie naar de Suriname-rivier. (R. H. WIJMANS, De Saramaccaner Boschnegers.) Tijdschr. Kon. Nederl. Aardr. Genootschap (2) 27 (p. III).

J. J. HARTSINCK, I770. Beschrijving van Guiana, of de Wilde Kust, in Zuid-America. II. (p. 757-798) G. Tielenburg, Amsterdam.

C. J. Hering, I9or. Verhandeling over de voedingsmiddelen der kolonie Suriname ... Paramaribo.

P. H. Hiss, 1943. Netherlands America. (p. 34-36) Duell, Sloan \& Pearce, New York.

W. R. van HoËVell, I855. Slaven en vrijen onder de Nederlandsche wet. I. (p. 38-47) J. Noman \& Zoon, Zaltbommel.

J. DE HooG, 1958. Suriname, een land in opkomst. (p. 26-29) Ethnografisch Museum, Delft. 
VOEDINGSGEWOONTEN VAN DE BOSLANDCREOOL 267

F. W. Hostmann, 1850. Over de beschaving van negers in Amerika, door kolonisatie met Europeanen. I. (p. 249-296) J. C. A. Sulpke, Amsterdam.

W. JoEST, 1893. Ethnographisches und Verwandtes aus Guayana. Intern. Archiv für Ethnographie 5, Suppl., p. 39-68.

O. J. R. Josefzoon, 1959. De Saramaccaanse wereld. Varekamp, Paramaribo.

L. JUNKER, 1944. Herinneringen aan het oerwoud. Uit mijn dagboek van 1923 en 1924. W. I. Gids 26, p. III-127, 129-146.

M. C. KAHN, 1931. Djuka - The Bush Negroes of Dutch Guiana. (p. 32, 48 , 65-90, 119-130) Viking Press, New York.

A. KAPPLER, 1854. Zes jaren in Suriname. Schetsen en tafereelen wit het maatschappelijke en militaire leven in deze Kolonie. II. (p. II5-13I) W. F. Dannenfelser, Utrecht.

Koloniaal Verslag van Suriname, I9II, 5, tekst. (p. I-2) Alg. Landsdrukkerij, 's-Gravenhage.

E. VAN DER KUYP, 1939. Verslag van een dienstreis naar de omgeving van Koffiekamp en Ganzee van 4-20 juli r939. (getypt verslag) Dienst Volksgezondheid, Suriname.

E. VAN DER KUYP, 1958. De voeding van de slaaf en de betekenis daarvan voor zijn nakomelingen. Emancipatreblad, I juli 1958, 20 pp.

A. F. Lammens, 1805. Mémoires (geschreven), I2, B 6. (p. 868)

H. LeERDAM, 1957. The Bushnegroes. (getypt rapport)

H. DE LeEuw, 1937. Onze West-Suriname. Wereldbibliotheek, Amsterdam.

L. LichtVeld, 1958. Van Bosnegers en Indianen. In Suriname in stroomlijnen. (p. 62-66) Wereldboog 120, Wereldbibliotheek, Amsterdam/ Antwerpen.

U. M. LichtVeld \& J. Voorhoeve, 1958. Suriname: Spiegel der vaderlandse kooplieden. (p. 97-98) W. E. J. Tjeenk Willink, Zwolle.

R. LUYKEN, 1960. Nutriënt-behoefte van enkele Surinaamse bevolkingsgroepen. (gestencild) Rapport Nr R I2I7 Centraal Instituut voor Voedingsonderzoek T.N.O., Utrecht, I4 Pp.

R. LUYKen, 1962. Voedingsfysiologisch onderzoek in Suriname. Nieuwe $W . I$. Gids 42 , ter perse.

R. LUYKen \& F. W. M. LuYKen - KonING, 1960. Studies on the physiology of nutrition in Surinam. I, II (\& H. K. OosterhUIS), III - VI. Tropical and geographical Medicine I2, p. 229-242, 303-3I4.

R. LUYKen \& F. W. M. LUYKen - Koning, I96r. Studies on the physiology of nutrition in Surinam. VII-IX. Trop. geogr. Med. 13, p. 42-54, 123-130.

A. J. H. van Lynden, 1939. Op zoek naar de zuidgrens. Tijdschr. Kon. Nederl. Aardr. Genootschap 56. (p. 39-40) 
M. G. Malmberg \& H. Labadie, 1944. Onderzoek van de Bosnegers aan de Marowijne. (getypt verslag) Dienst Volksgezondheid, Suriname.

W. R. Menkman, 1946. Uit de geschiedenis der opening van het Surinaamsche binnenland (door J. F. A. Cateau van Rosevelt \& J. F. A. E. van Lansberge). W. I. Gids 27, p. 182-192, 289-299, 321-343.

H. A. Poindexter, 1958. A tour of duty in Suriname. (gestencild verslag)

A. Sausse, 195I. Populations primitives du Maroni. (p. 43, 49-55). Inst. Géographique National, Paris.

H. G. Schneider, 1893. Die Buschneger Surinames. Allg. MissionsZeitschrift von D. G. Warneck. C. Bertelsmann, Güttersloh.

G. J. StaAl, 1928. Nederlandsch Guyana. (p. 179-180, 184) Bibliotheek voor cultuur en wetenschap Groot Nederland, Amsterdam.

G. Stahel, 1944. De nuttige planten van Suriname. (p. I4-112) Depart. Landbouwproefstation Suriname 59.

J. G. Stedmann, 1799-180o. Reize naar Surinamen, en door de binnenste gedeelten van Guiana. I (p. 9I, 202, 204, 208, 214-2I5), II (p. 238), III (p. 15, 24, 30, 37-44). J. Allart, Amsterdam.

H. G. Steinberg, met medewerking van G. J. StaAl, 1933. Ons Suriname. De zending der Evangelische Broedergemeente in Nederlandsch Guyana. (p. 225-226) Alg. Boekhandel voor inwendige en uitwendige Zending, 's-Gravenhage.

C. A. VAn Sypesteyn, 1854. Beschrijving van Suriname. (p. 159) Gebr. Van Cleef, 's-Gravenhage.

M. D. Teenstra, 1835. De landbouw in de kolonie Suriname. II. (p. I66I7I) $\mathrm{H}$. Eekhoff $\mathrm{Hz}$, Groningen.

J. W. VANDERCOOK, 1926. Tom-tom. (p. 59, IO2-IO9, I2I-129, 136-137, 177-178, 204, 234-235) Harpers, New York / London.

-G. Versteeg, 1905. Op expeditie in Suriname. Elsevier geill. Maandschr., p. $317-328$.

R. Voullaire, 19i6. Onze Boschnegers in Suriname. Berichten uit de Heidenwereld 7, Zeist, p. 102-108. 
Bush Negroes or Bushland Creoles are descendants of runaway African slaves who settled in villages, chiefly in the interior beyond the waterfalls, along the upper courses of the rivers. There, they could adapt themselves without great difficulty, as the Surinam interior is similar to their previous African environment.

These semi-savages have retained their ancestors' West African culture because they have been isolated. Their food habits are based on tradition, religion and superstition. However, they have adopted some habits from other ethnic groups, as follows:

I. the Amerindians: cassava bread, wild fruits, barbecuing, cassareep;

2. the Europeans: alcohol, kitchen utensils, culinary technique, guns;

3. the Jews: cleanliness, food taboos (pork, fish without scales), abstinence on Saturday (from hunting and eating game).

Their culture has also been modified by their:

I. previous enslavement: poorly balanced diet, alcoholism (provision of blunt calories for working hard), aversion to agriculture;

2. life on the plantation: monotonous diet, begging, purchase of food;

3. previous persecution: wild fruits, hidden agricultural grounds, no cattleraising;

4. new environment in the Surinam interior: shifting of cultivation grounds, fishing practice, bush products (palm wine, wild honey).

In this article a chronological summary is presented of previous papers on the food and nutrition of the Bush Negroes.

They obtain (obtained) their food, etc., by:

I. growing some crops on their own grounds

2. gathering wild fruits, seeds, honey, palm wine and insects

3. hunting (game and fowl)

4. fishing for fish, crabs and shrimps

5. raising chickens and tortoises 
6. buying in shops: codfish, bacon, oil, alcoholic and soft drinks, salt, tobacco

7. bartering: utensils, hunting equipment, salt, sugar, gin, rum

8. begging: bread, biscuit, sweets, alcoholic drinks, tobacco

9. receiving gifts from tourists and the Government (especially during famines): rice, titbits, sweets, gin, rum, codfish, tobacco, hunting equipment; and from the United Nations Children's Fund: dried skim milk

Io. plundering the plantations (during the past persecution)

II. breast feeding (small children are breast-fed even after their second year)

The diet of the Bush Negroes is very limited. The main staple foods are baked flour of cassava or manioc (Manihot esculenta) and rice (Oryza sativa). Other staple foods are: plantain (Musa paradisiaca), sweet potato (Ipomoea batatas), taro or yautia (Xanthosoma sp.), yams (Dioscorea alata), nappie (Dioscorea sativa or D. trifida) and maize (Zea mais). Sometimes peanuts, sugar cane, pepper and ochre are cultivated.

To grow sufficient vegetable food, the Bush Negroes must shift their cultivation grounds frequently. Pests (leaf-cutting ants), heavy rains which leach the minerals out of the soil, and reckless agricultural methods which rapidly deplete the soil, force them to rove farther from their village in search of new land. In addition they consider agriculture degrading work, since their ancestors were cruelly treated on the plantations. Other threats to an adequate supply of vegetable food are birds, drought and plant diseases.

Some fruit trees are cultivated in the village, whilst the bush provides some palm fruits from which drinks and oils are made. Beans, peas and vegetables are planted very rarely.

No cattle are raised. This omission is partly an West African heritage. But it also has another origin. During the period of persecution of the runaway slaves, animals could not be kept, as they might betray their owners' hiding-places. Another reason is the lack of pastures. Therefore milk is not used. Some Bush Negroes keep a few chickens.

Although the interior is qualitatively very rich in animals, it is no longer so quantitatively in the inhabited areas, owing to unlimited hunting and fishing (with fish poisons). In addition, the Bush Negroes are not as skilled in hunting and fishing as the Amerindians. 
VOEDINGSGEWOONTEN VAN DE BOSLANDCREOOL 27 I

Their diet is therefore over-abundant in carbohydrates, but deficient in animal products, fruits and vegetables. As a result, it lacks vegetable and especially animal proteins, animal fats, mineral salts and vitamins.

The Bush Negroes like rum, gin, beer and liqueur, but they do not consume as much alcohol as the Amerindians. The women are fond of smoking a pipe while the men like taking snuff.

The primitive Africans showed no clinical signs of dietary deficiencies, as they could obtain a great variety of foods from their primitive system of horticulture, from the bush flora, and also from hunting and fishing. But as soon as they became the property of a European or Jewish plantation owner in Surinam, and came into contact with western civilization, their nutritional habits changed and typical deficiency diseases developed.

The present-day poorly balanced and monotonous diet of the Bush Negroes is therefore not an African heritage, but is due to the days of slavery and life on the plantation.

Cassava, which plays such a major part in the nutrition of this area, is extremely lacking in proteins, fat, salts and vitamins. To try to get the needed proteins, the Bush Negroes instinctively consume huge amounts of cassava bread, piled like the tower of Babel. This mammoth intake is a matter not of greed but of necessity.

Digestion of such a quantity of carbohydrates requires large doses of thiamin and niacin. As the supply of these vitamins is small, and the amount needed is great, most of the adults suffer from avitaminosis (B-complex).

The abundant consumption of carbohydrates is one of the causes of 'cassava belly' in children. 